VILNIAUS GEDIMINO TECHNIKOS UNIVERSITETAS

Gediminas STAIGVILA

\title{
MIKROSEKUNDINIŲ MAGNETINIŲ IMPULSŲ GENERATORIŲ KŪRIMAS LĄSTELIŲ PLAZMINĖS MEMBRANOS PRALAIDUMUI VALDYTI
}

DAKTARO DISERTACIJA

TECHNOLOGIJOS MOKSLAI,

ELEKTROS IR ELEKTRONIKOS INŽINERIJA (T 001)

Vilnius, 2020 
Disertacija rengta 2016-2020 metais Vilniaus Gedimino technikos universitete.

\section{Vadovas}

doc. dr. Vitalij NOVICKIJ (Vilniaus Gedimino technikos universitetas, elektros ir elektronikos inžinerija - T 001).

Vilniaus Gedimino technikos universiteto Elektros ir elektronikos inžinerijos mokslo krypties disertacijos gynimo taryba:

\section{Pirmininkas}

prof. dr. Algirdas BAŠKYS (Vilniaus Gedimino technikos universitetas, elektros ir elektronikos inžinerija - T 001).

\section{Nariai:}

dr. Matej REBERŠEK (Liublianos universitetas, Slovėnija, elektros ir elektronikos inžinerija - T 001),

prof. dr. Artūras SERACKIS (Vilniaus Gedimino technikos universitetas, elektros ir elektronikos inžinerija - T 001),

doc. dr. Dainius UDRIS (Vilniaus Gedimino technikos universitetas, elektros ir elektronikos inžinerija - T 001),

prof. dr. Algimantas VALINEVIČIUS (Kauno technologijos universitetas, elektros ir elektronikos inžinerija - T 001).

Disertacija bus ginama viešame Elektros ir elektronikos inžinerijos mokslo krypties disertacijos gynimo tarybos posėdyje $2021 \mathrm{~m}$. sausio 7 d. 10 val. Vilniaus Gedimino technikos universiteto senato posèdžių salëje.

Adresas: Saulètekio al. 11, LT-10223 Vilnius, Lietuva.

Tel.: (8 5) 274 4956; faksas (8 5) 270 0112; el. paštas doktor@vgtu.lt

Pranešimai apie numatomą ginti disertaciją išsiųsti 2020 m. gruodžio 4 d.

Disertaciją galima peržiūrèti Vilniaus Gedimino technikos universiteto talpykloje http://dspace.vgtu.lt, Vilniaus Gedimino technikos universiteto bibliotekoje (Saulètekio al. 14, LT-10223 Vilnius, Lietuva) bei Lietuvos mokslų akademijos Vrublevskių bibliotekoje (Žygimantų g. 1, LT-01102 Vilnius, Lietuva).

Vilniaus Gedimino technikos universiteto 2020-044-M mokslo literatūros knyga doi:10.20334/2020-044-M

(C) Vilniaus Gedimino technikos universitetas, 2020

(C) Gediminas Staigvila, 2020

gediminas.staigvila@vgtu.lt 
VILNIUS GEDIMINAS TECHNICAL UNIVERSITY

Gediminas STAIGVILA

\section{DEVELOPMENT OF MICROSECOND MAGNETIC PULSE GENERATORS FOR CELL MEMBRANE PERMEABILIZATION CONTROL}

DOCTORAL DISSERTATION

TECHNOLOGICAL SCIENCES,

ELECTRICAL AND ELECTRONIC ENGINEERING (T 001)

Vilnius, 2020 
Doctoral dissertation was prepared at Vilnius Gediminas Technical University in 2016-2020.

\section{Supervisor}

Assoc. Prof. Dr Vitalij NOVICKIJ (Vilnius Gediminas Technical University, Electrical and Electronic Engineering - T 001).

The Dissertation Defence Council of Scientific Field of Electrical and Electronic Engineering of Vilnius Gediminas Technical University.

\section{Chairman}

Prof. Dr Algirdas BAŠKYS (Vilnius Gediminas Technical University, Electrical and Electronic Engineering - T 001).

\section{Members:}

Dr Matej REBERŠEK (University of Ljubljana, Slovenia, Electrical and Electronic Engineering - T 001),

Prof. Dr Artūras SERACKIS (Vilnius Gediminas Technical University, Electrical and Electronic Engineering - T 001),

Assoc. Prof. Dr Dainius UDRIS (Vilnius Gediminas Technical University, Electrical and Electronic Engineering - T 001),

Prof. Dr Algimantas VALINEVIČIUS (Kaunas University of Technology, Electrical and Electronic Engineering - T 001).

The dissertation will be defended at the public meeting of the Dissertation Defence Council of Electrical and Electronic Engineering in the Senate Hall of Vilnius Gediminas Technical University at $\mathbf{1 0}$ a. m. on 7 January 2021.

Address: Saulètekio al. 11, LT-10223 Vilnius, Lithuania.

Tel.: +370 5274 4956; fax +370 5270 0112; e-mail: doktor@vgtu.lt

A notification on the intend defending of the dissertation was send on 4 December 2020.

A copy of the doctoral dissertation is available for review at Vilnius Gediminas Technical University repository http://dspace.vgtu.lt, at the Library of Vilnius Gediminas Technical University (Sauletekio al. 14, LT-10223 Vilnius, Lithuania) and the Wroblewski Library of the Lithuanian Academy of Sciences (Žygimantu st. 1, LT-01102, Vilnius, Lithuania). 


\section{Reziumè}

Disertacijoje nagrinėjami magnetinio lauko impulsų generatoriai ir technologijos, skirtos valdyti ląstelès plazminès membranos pralaidumą. Naudojant impulsinius induktorius kaip apkrovą, disertacijoje buvo bandoma bekontktiniu būdu indukuoti grịžtamus ir negrịžtamus pokyčius biologiniuose objektuose, apžvelgiamos sukuriamo magnetinio lauko impulsų poveikio priklausomybės nuo impulso formos ir kitų parametrų.

Disertaciją sudaro įvadas, trys skyriai, bendrosios išvados, naudotos literatūros ir autoriaus publikacijų disertacijos tema sąrašai.

Ivadiniame skyriuje aptariama tiriamoji problema, darbo aktualumas, aprašomas tyrimų objektas, formuluojamas darbo tikslas bei uždaviniai, aprašoma tyrimų metodika, darbo mokslinis naujumas, darbo rezultatų praktinè reikšmè, ginamieji teiginiai. Ivado pabaigoje pristatomos disertacijos tema autoriaus paskelbtos publikacijos ir pranešimai konferencijose bei disertacijos struktūra.

Pirmasis skyrius skirtas literatūros apžvalgai. Jame analizuojami įvairių generatorių schemų veikimo principai ir pritaikymas. Skyriaus pabaigoje formuluojamos išvados ir tikslinami disertacijos uždaviniai.

Antrajame skyriuje aprašomi Markso topologijos, ignitrono ir tiristorių pagrindu sukurti magnetinio lauko generatoriai bei apžvelgiami atskirų grandinių veikimo principai.

Trečiajame skyriuje pateikti induktorių imitacinių modelių tyrimo rezultatai, indukuoto elektrinio lauko parametrai bei taikomujų eksperimentų rezultatai su skirtingų tipų ląstelèmis.

Disertacijos tema paskelbti 5 straipsniai: keturi - moksliniuose žurnaluose, įtrauktuose ị Clarivate Analytics Web of Science saraša, turinčiuose citavimo indeksą, vienas - konferencijų medžiagoje, ịtrauktoje ị Clarivate Analytics Web of Science duomenų bazę. Disertacijos tema perskaityti 8 pranešimai nacionalinėse bei tarptautinèse konferencijose. 


\section{Abstract}

The dissertation deals with magnetic field pulse generators and technologies for controlling the plasma membrane permeability of cells. In this work, pulse inductors were used as a load, the work, and attempted contactlessly induce reversible and irreversible changes in biological objects, by magnetic field pulses of different shapes and parameters.

The dissertation consists of an introduction, three chapters, general conclusions, references and lists of the author's publications on the topic of the dissertation.

The introductory chapter discusses the research problem, the relevance of the work, describes the object of research, formulates the aim and objectives of the work, describes the research methodology, scientific novelty, the practical significance of results, defended statements. At the end of the introduction, the author's publications and conference papers on the topic of the dissertation and the structure of the dissertation are presented.

The first chapter is devoted to a review of the literature. It presents the principles of operation and application of various generator circuits. At the end of the chapter, conclusions are formulated and the tasks of the dissertation are specified.

The second chapter describes the three developed magnetic field generators and working principle of separate circuits.

The third chapter presents the results of inductor simulation models, the parameters of the induced electric field and the results of applied experiments with different cell types.

On the topic of the dissertation 5 articles were published: four in scientific journals included in the Clarivate Analytics Web of Science list with impact factor, and one in conference proceedings included in the Clarivate Analytics Web of Science database. 8 presentations on the topic of the dissertation were read at national and international conferences. 


\section{Žymëjimai}

\section{Santrumpos}

B - (angl. magnetic field) magnetinio srauto tankis;

BJT - (angl. bipolar junction transistor) dvipolis tranzistorius;

CFU - (angl. colony-forming unit) kolonijas formuojantys vienetai;

$\mathrm{CHO}$ - (angl. Chinese hamster ovary cell) Kiniško žiurkėno kiaušidžių ląstelès;

$\mathrm{DC}$ - (angl. direct current) nuolatinè srove;

$\mathrm{E}-$ (angl. electric field) elektrinis laukas;

GTO - (angl. gate turn-off thyristor) valdomo išjungimo tiristorius;

$\mathrm{HV}$ - (angl. high voltage) aukštoji ịtampa;

HVHCS - (angl. arc-quenching chambers of high-voltage high-current switches) aukštos ịtampos aukštos srovès jungiklių lanko gesinimo kameros;

IEBA - (angl. intense electron-beam accelerator) intensyvus elektronų pluošto greitintuvas;

IGBT - (angl. insulated-gate bipolar transistor) dvipolis tranzistorius su izoliuota užtūra;

MOSFET - (angl. metal-oxide-semiconductor field-effect transistor) metalo, oksido ir puslaidininkio lauko efekto tranzistorius;

PEMF - (angl. pulsed electromagnetic field) impulsiniai elektriniai ir magnetiniai laukai; 
PGR - (angl. polymerase chain reaction) polimerazės grandinės reakcija;

PI - (angl. propidium iodide) propidžio jodidas;

PMF - (angl. pulsed magnetic field) impulsiniai magnetiniai laukai;

PWM - (angl. pulsed width modulation) impulsų pločio moduliacija;

RMF - (angl. rotating magnetic field) besisukantys magnetiniai laukai;

SCR - (angl. silicon controlled rectifier) tiristorius;

SMF - (angl. strong magnetic field) stiprūs magnetiniai laukai;

TMS - (angl. transcranial magnetic stimulation) galvos magnetinè stimuliacija;

TRD - (angl. galvanically isolated trigger) galvaniškai atskirtas trigeris. 


\section{Turinys}

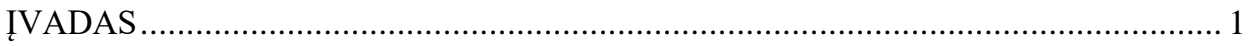

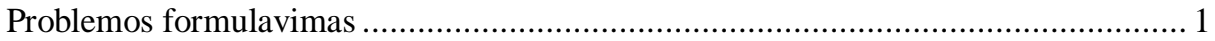

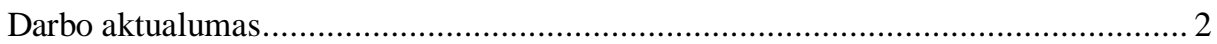

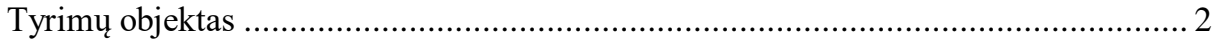

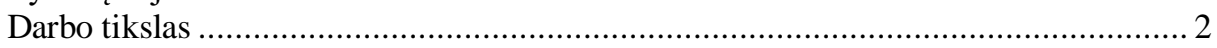

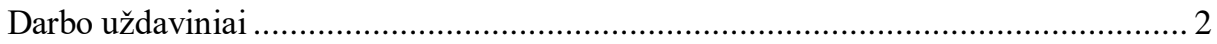

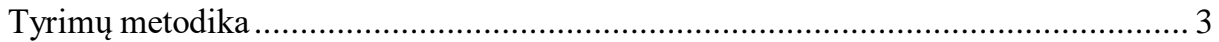

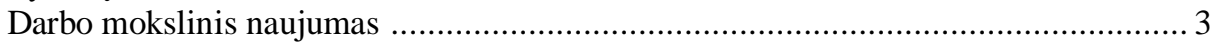

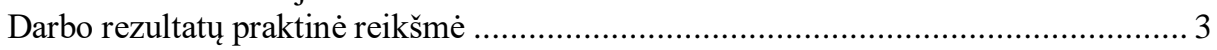

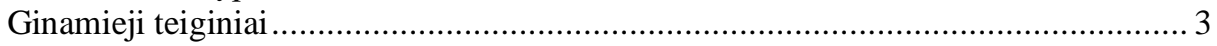

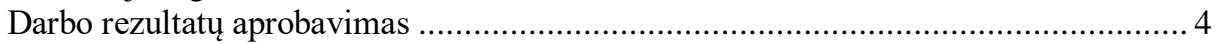

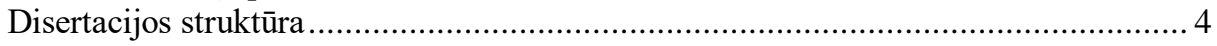

1. MAGNETINIO LAUKO GENERAVIMO TECHNOLOGIJŲ IR JŲ TAIKYMŲ

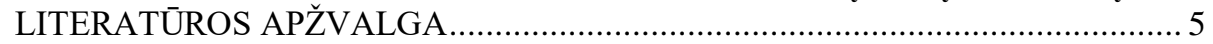

1.1. Elektromagnetinių laukų taikymai biomedicinoje ir biotechnologijose ................... 5

1.2. Stiprių impulsinių elektromagnetinių laukų taikymai biotechnologijoje................ 7

1.3. Ittaisai naudojami stipraus magnetinio lauko generatoriuose .............................. 8

1.4. Esamos magnetinio lauko generatorių technologijos ........................................ 13

1.5. Pirmojo skyriaus išvados ir disertacijos uždavinių formulavimas ...................... 23 
2. IMPULSINIŲ DIDELĖS GALIOS GENERATORIŲ KŪRIMAS IR TYRIMAS .... 25

2.1. Markso topologija gristas magnetinio lauko generatorius ............................... 25

2.2. Magnetinio lauko generatorius su ignitrono raktu ................................. 30

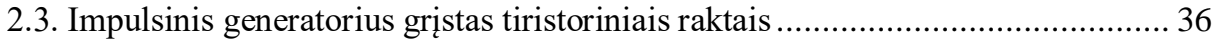

2.4. Generatorių skirtų magnetoporacijai palyginimas ................................ 40

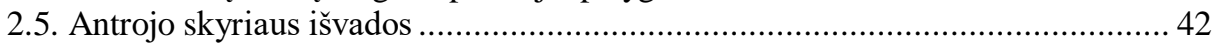

3. SUKURTŲ IMPULSINIŲ INDUKTORIŲ ANALIZE் IR TAIKOMIEJI

MAGNETOPORACIJOS TYRIMAI........................................................ 43

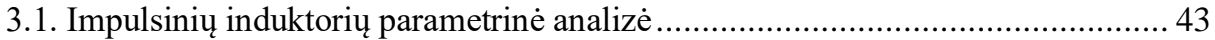

3.2. Taikomieji magnetoporacijos tyrimai .................................................. 49

3.3. Trečiojo skyriaus išvados ............................................................ 50

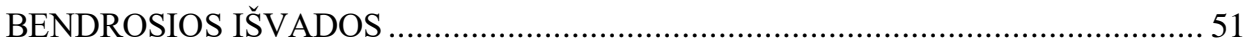

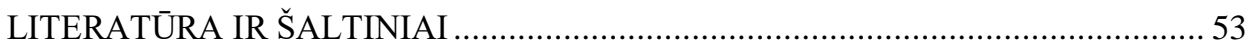

AUTORIAUS MOKSLINIŲ PUBLIKACIJŲ DISERTACIJOS TEMA SĄRAŠAS .... 63

SUMMARY IN ENGLISH................................................................... 77

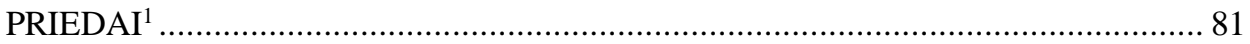

A priedas. Disertacijos autoriaus sąžiningumo deklaracija.................................. 83

B priedas. Bendraautorių sutikimai teikti publikacijose skelbtą medžiagą mokslo daktaro disertacijoje ...................................................................... 84

C priedas. Autoriaus mokslinių publikacijų disertacijos tema kopijos ................... 99

${ }^{1}$ Priedai pateikti pridètoje kompaktinèje plokštelèje. 


\section{Contents}

INTRODUCTION

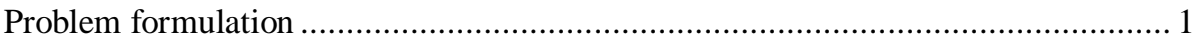

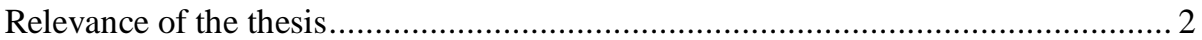

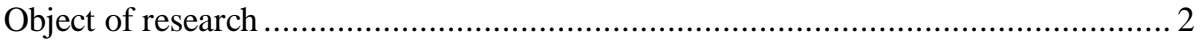

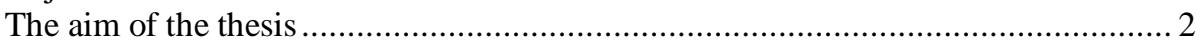

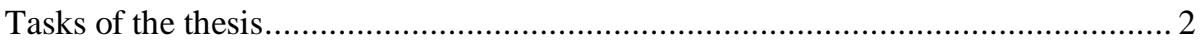

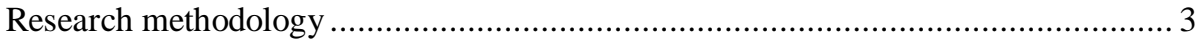

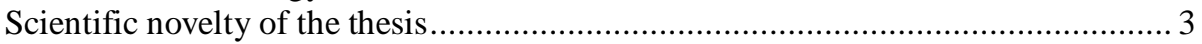

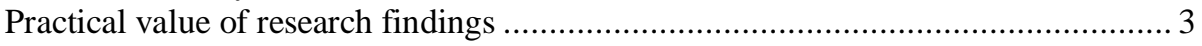

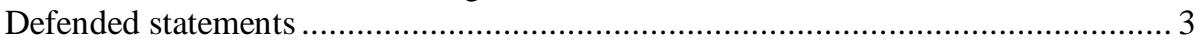

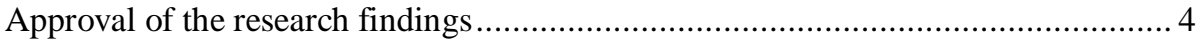

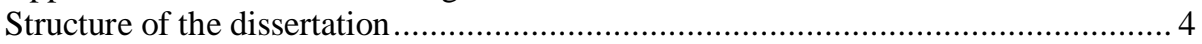

\section{LITERATURE OVERVIEW OF MAGNETIC FIELD GENERATION} TECHNOLOGIES AND APPLICATIONS …………...................................... 5

1.1. Applications of electromagnetic fields in biomedicine and biotechnology .......... 5

1.2. Applications of strong pulsed electromagnetic fields in biotechnology .............. 7

1.3. The devices are used in strong magnetic field generators ................................... 8

1.4. Existing magnetic field generator technologies.............................................. 13

1.5. Conclusions of the first chapter and formulation of dissertation tasks .............. 23 
2. DEVELOPMENT AND RESEARCH OF HIGH POWER PULSE

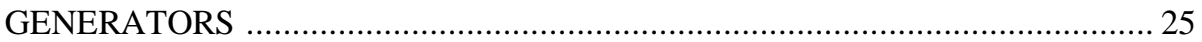

2.1. A magnetic field generator based on the Marx topology ................................ 25

2.2. Magnetic field generator with ignitron key................................................. 30

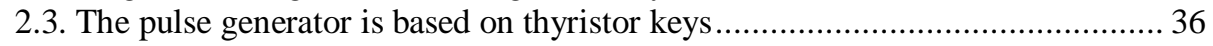

2.4. Comparison of generators for magnetoporation .............................................. 40

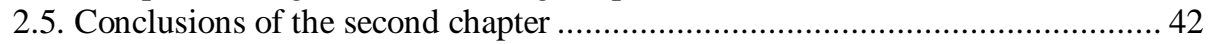

3. ANALYSIS OF DEVELOPED PULSED INDUCTORS AND APPLIED MAGNETOPORATION RESEARCH ......................................................... 43

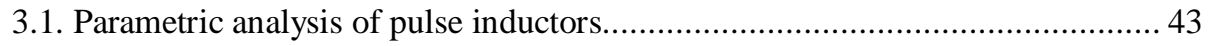

3.2. Applied magnetoporation research ........................................................... 49

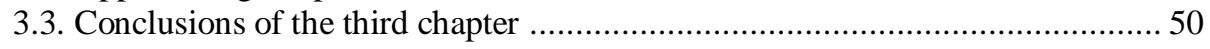

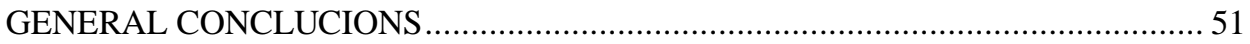

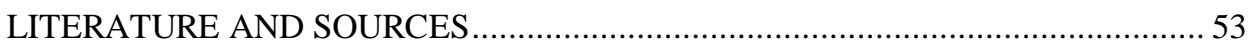

AUTHOR'S PUBLICATION ON THE TOPIC OF THE DISSERTATION.................. 63

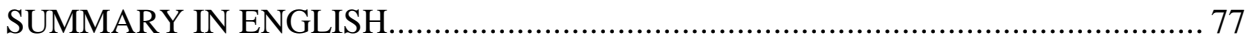

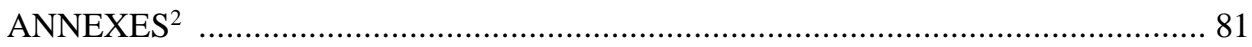

Annex A. Dissertation author's declaration of academic integrity .......................... 83

Annex B. Co-authors' consents to submit the material published in the publications

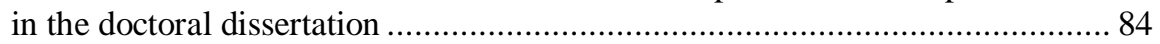

Annex C. Copies of the author's scientific publications on the topic of the dissertation.

${ }^{2}$ The annexes are supplied in the enclosed compact disc. 


\section{Ivadas}

\section{Problemos formulavimas}

Elektroporacija tai elektrinio lauko iššauktas reiškinys, leidžiantis valdyti biologinių ląstelių plazminès membranos pralaidumą. Jis naudojamas biomedicinoje ir biotechnologijose, vaistams ir genams įterpti ị ląsteles, audinių abliacijai, vakcinacijai, maisto perdirbimui, biorafinavimui, baltymų ekstrakcijai.

Magnetoporacija - tai stiprių magnetinių laukų sukeltas reiškinys, kuris savo poveikiu yra panašus i elektroporaciją. Skirtingai nuo elektroporacijos padidintas ląsteliu pralaidumas yra iššaukiamas be tiesioginio kontakto su bandiniu, tačiau poveikio mechanizmas nèra pilnai ištirtas, o taikomujų mokslinių darbų su parametrine analize skaičius yra ribotas. Dèl šių priežasčiu kuriami nauji magnetinio lauko generatoriai ir impulsiniai induktoriai, kurie naudojami magnetoporacijai.

Tačiau, norint sugeneruoti pakankamai stiprų magnetinị lauką, reikia taikyti impulsines sroves, kurių diapazonas gali siekti nuo kelių šimtų amperų iki kelių kiloamperų, ir dèl to atsiranda Džaulio šilumos ir jos valdymo problemos (V. Novickij et al., 2013). Atitinkamai, dèl technologinių problemų ir inžinierinio sudètingumo dauguma mokslinių darbų apsiriboja $\mu \mathrm{T}-\mathrm{mT}$ diapazono impulsiniais magnetiniais laukais arba statinio iki $2 \mathrm{~T}$ magnetinio lauko impulsų generavimo technologijomis (Bae et al., 2011; Ghodbane et al., 2013; Radhakrishnan et al., 
2012). Tačiau, norint sukelti detektuojamus pokyčius biologinėse ląstelèse reikalingi impulsiniai generatoriai formuojantys aukšto magnetinio lauko pokyčio per laiko vienetą $(\mathrm{d} B / \mathrm{d} t)$ impulsus.

Dėl šių priežasčių reikia tolimesnių tyrimų ir technologijų vystymo, norint užtikrinti naujų ląstelių membranos pralaidumo metodų sukūrimą ir integraciją biomedicinos ar biotechnologijų srityse.

\section{Darbo aktualumas}

Šiuo metu trūksta magnetinio lauko impulsinių sistemų, kurios gali būti taikomos ląstelių membranų pralaidumo tyrimuose. Dẻl šių priežasčiu pats ląstelių membranos pralaidumo reiškinys yra nepakankamai ištirtas, o pritaikymas daugumoje atveju apribotas ikiklinikiniais tyrimais. Naujų technologinių sprendimų šioje srityje sukūrimas potencialiai leistų padidinti šios technologijos prieinamumą.

\section{Tyrimu objektas}

Darbo tyrimų objektas - didelès galios impulsiniai magnetinio lauko generatoriai ląstelių membranų pralaidumą valdančių aukšto magnetinio lauko pokyčio per laiko vienetą impulsų formavimui.

\section{Darbo tikslas}

Šio darbo tikslas sukurti magnetinio lauko generatorius, kurie be tiesioginio kontakto su bandiniu sukeltų valdomus ląstelių membranų pralaidumo pokyčius.

\section{Darbo uždaviniai}

Darbo tikslui pasiekti darbe reikia spręsti šiuos uždavinius:

1. Ištirti didelès galios impulsų technologijas ir pasiūlyti aukšto magnetinio lauko pokyčio per laiko vienetą magnetinių impulsų formavimo grandines, skirtas biologinių ląstelių membranų pralaidumo valdymui be tiesioginio kontakto su bandiniu.

2. İvertinti impulsinių induktorių struktūrą, indukuoto elektrinio lauko pasiskirstymus, ịšilimo efektus ir užtikrinti induktoriuose stabilią temperatūrą poveikio metu.

3. Atlikti taikomuosius eksperimentinius sukurtų generatorių tyrimus, parodant fluorescencinių dažų pernašą per biologinių ląstelių membraną. 


\section{Tyrimų metodika}

Darbe taikomi skaitmeninio imitavimo ir eksperimentiniai tyrimo metodai: skaitmeninio imitavimo metodai COMSOL aplinkoje, eksperimentiniai elektronikos grandinių signalų apdorojimo metodai; tekmès citometrija ir fluorescencinių dažų pernašos metodai.

\section{Darbo mokslinis naujumas}

Rengiant disertaciją buvo gauti šie elektros ir elektronikos inžinerijos mokslui reikšmingi rezultatai:

1. Sukurti impulsinių induktorių imitaciniai modeliai ir nustatyti tiksliniai lauko parametrai ląstelių membranų pralaidumo valdymui.

2. Sukurtas Markso topogijos magnetinio lauko generatorius, taikytinas magnetoporacijos tyrimuose, skirtas formuoti 3,3 T magnetinio lauko 450-500 ns fronto impulsus $100 \mu \mathrm{l}$ tūryje.

3. Sukurtas generatorius su ignitronu impulsų formavimo grandinėje, galintis generuoti iki $3 \mathrm{~T}$ magnetinio lauko 650-700 ns fronto impulsus $100 \mu l$ tūryje, užtikrinant impulsų amplitudès ir dažnio valdymą.

4. Sukurtas impulsų generatorius, taikytinas magnetoporacijos tyrimuose, su tiristorine impulsų formavimo grandine, galintis generuoti iki 10 T magnetinio lauko mikrosekundinès trukmès $(10-15 \mu \mathrm{s}) \mathrm{im}-$ pulsus $50 \mu$ tūryje, užtikrinant impulsų amplitudès ir dažnio valdymą.

\section{Darbo rezultatų praktinè reikšmè}

Darbo rezultatai pritaikomi magnetoporacijos srityje ir prisideda prie šio biologinio reiškinio supratimo ir metodikos vystymo. Darbo rezultatai taip pat buvo panaudoti vykdant Link ateities technologijų programos projektą LAT-16001 „Mikrogravitacijos sąlygose suaktyvėjančių ir odos infekcijas sukeliančių mikroorganizmų biokontrolè naudojant elektro-magnetoporaciją““.

\section{Ginamieji teiginiai}

1. Markso grandinès topologijos 3,3 T sub-mikrosekundinio fronto impulsų generatorių galima taikyti magnetoporacijos tyrimuose, užtikri- 
nant iki $0,2 \mathrm{kV} / \mathrm{cm}$ indukuoto elektrinio lauko generavimą ląstelių suspensijoje, neviršijant $3{ }^{\circ} \mathrm{C}$ temperatūros pokyčių induktoriaus efektyviame tūryje.

2. Sukurta impulsų formavimo grandinè, naudojant ignitroną, užtikrina pasikartojančių iki $5 \mathrm{kA}$ impulsų formavimą su 650-700 ns frontu, naudojant apkrovas artimas trumpajam jungimui ir gali būti taikoma aukšto $\mathrm{d} B / \mathrm{d} t$ magnetinių impulsų formavimui.

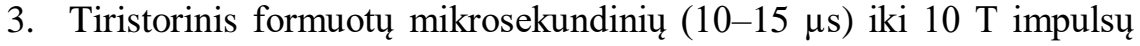
generatorius yra tinkamas indukuoti padidintą ląstelių membranos pralaidumą, neviršijant $5{ }^{\circ} \mathrm{C}$ temperatūros pokyčių induktoriaus efektyviame tūryje.

\section{Darbo rezultatų aprobavimas}

Disertacijos tema paskelbti 5 straipsniai: keturi - moksliniuose žurnaluose, itrauktuose į Clarivate Analytics Web of Science sąrašą (V. Novickij 2017, V. Novickij 2018, Staigvila 2019, V. Novickij 2020), turinčiuose citavimo rodikli, vienas konferencijų medžiagoje (Staigvila 2017), įtrauktoje ị Clarivate Analytics Web of Science duomenų bazę.

Disertacijoje atliktų tyrimų rezultatai buvo paskelbti aštuoniose mokslinèse konferencijose Lietuvoje ir užsienyje:

- Jaunuju mokslininkų konferencijoje „Elektronika ir elektrotechnika“ 2017, 2018, 2019 m. Vilniuje;

- Tarptautinejje konferencijoje „Open Readings“ 2017, 2019 m. Vilniuje;

- Tarptautinejje konferencijoje „Electronics“ 2017 m. Palangoje;

- Tarptautineje konferencijoje ,The 5th IEEE Workshop on Advances in Information, Electronic and Electrical Engineering AIEEE'2017“' 2017 m., Rygoje.

- Tarptautineje konferencijoje „The 3rd World Congress on Electroporation and Pulsed Electric Fields in Biology, Medicine, and Food \& Environmental Technologies“ $2019 \mathrm{~m}$. Tulūzoje.

\section{Disertacijos struktūra}

Disertaciją sudaro įvadas, trys skyriai ir bendrosios išvados. Taip pat yra 3 priedai.

Darbo apimtis yra 82 puslapiai, neskaitant priedų, 37 paveikslai ir 4 lentelés. Rašant disertaciją buvo panaudota 104 literatūros šaltiniai. 


\section{1}

\section{Magnetinio lauko generavimo technologijų ir jų taikymų literatūros apžvalga}

Šiame skyriuje apžvelgiami magnetinių impulsų taikymai biomedicinoje ir biotechnologijose, magnetinio lauko generavimo metodai, itaisai ir induktoriai, kurie naudojami magnetinio lauko generatoriuose. Taip pat skyriuje apžvelgiamos pereinamujų procesų kompensavimo grandinès ir jų taikymai. Dalis skyriuje pateiktos medžiagos skelbta autoriaus mokslinèse publikacijose (V. Novickij, et al., 2017, Staigvila, et al., 2019).

\subsection{Elektromagnetinių laukų taikymai biomedicinoje ir biotechnologijose}

Magnetiniai laukai apima stiprius magnetinius laukus SMF (angl. strong magnetic field), impulsinius elektromagnetinius laukus PEMF (angl. pulsed electromagnetic field), besisukančius magnetinius laukus RMF (angl. rotating magnetic field) ir kintamuosius elektromagnetinius laukus. Magnetoterapija yra neinvazinis, saugus ir paprastas būdas gydyti sužalojimo vietą, skausmo ir uždegimo šaltinį bei kitas ligas. SMF ir PEMF yra du modifikuoti magnetinių laukų tipai. SMF buvo 
suskirstyti ị kategorijas pagal jų intensyvumą: ypač silpnas $(5 \mu \mathrm{T}-1 \mathrm{mT})$, silpnas $(1 \mathrm{mT})$, vidutinis $(1 \mathrm{mT}-1 \mathrm{~T})$, stiprus $(1-5 \mathrm{~T})$ ir ypač stiprus $(>5 \mathrm{~T})(\mathrm{Xia}$ et al., 2018). Silpni magnetiniai laukai taip pat gali veikti ịvairias ląsteles. Taip valdant jonų pernaša galima bakterijų ląstelèse. Taip pat veikiant ląsteles magnetiniu lauku sutrinka ląstelių judrumas ir dauginimosi greitis. Dauginimosi greitis priklauso nuo magnetinio lauko stiprumo (Masood, et al., 2017).

Magnetinio lauko intensyvumo poveikio pavyzdžiai biologinèms ląstelèms pateikti 1.1 lentelèje.

1.1 lentelè. Magnetinio lauko poveikis biologinèms ląstelèms (Albuquerque et al., 2016)

Table 1.1. Magnetic field effects on biological cells (Albuquerque et al., 2016)

\begin{tabular}{|c|c|c|}
\hline $\begin{array}{l}\text { Magnetinio } \\
\text { lauko inten- } \\
\text { syvumas, } \\
\mathrm{mT}\end{array}$ & Lastelès & Magnetinio lauko poveikis \\
\hline 200 & $\begin{array}{l}\text { Salmonella } \\
\text { (May, et al., 2009) }\end{array}$ & $\begin{array}{l}\text { Ląstelių augimui neturejo ịtakos, tačiau } \\
\text { sumažejo kolonijų nuo 3-6 h ir vèl pra- } \\
\text { dėjo didèti nuo } 6-9 \mathrm{~h}\end{array}$ \\
\hline 35 iki 120 & $\begin{array}{l}\text { Fibroblastai, melanomos } \\
\text { ląstelès ir adipozė } \\
\text { kamieninès ląstelès } \\
\text { (Sullivan } \text { et al., 2011) }\end{array}$ & $\begin{array}{l}20 \% \text { slopina žmogaus melanomos ląste- } \\
\text { lių augimą ir nedaro jokio poveikio ka- } \\
\text { mieninèms ląstelèms }\end{array}$ \\
\hline 300 & $\begin{array}{l}\text { Miofibroblastai } \\
\text { (Gruchlik et al., 2012) }\end{array}$ & $\begin{array}{l}\text { Ląsteliu proliferacija padidèjo nepakitus } \\
\text { ląstelių gyvybingumui, veikiant SMF }\end{array}$ \\
\hline 12 & $\begin{array}{l}\text { Endotelio ląstelès } \\
\text { (Martino et al., 2010) }\end{array}$ & $\begin{array}{l}\text { Ląstelių skaičius padidèjo } 40 \% \text {, lygi- } \\
\text { nant su kontroline grupe }\end{array}$ \\
\hline 220 & $\begin{array}{l}\text { Saccharomyces cerevsiae } \\
\text { (Muniz et al. 2007) }\end{array}$ & Biomasè padidèjo 2,5 karto \\
\hline 15 & $\begin{array}{l}\text { Žiurkès kaulų čiulpu ka- } \\
\text { mieninès ląstelès } \\
\text { (Sarvestani, et al., 2010) }\end{array}$ & $\begin{array}{l}\text { Ląstelių skaičiaus padidëjimas } \mathrm{G} 2 / \mathrm{M} \\
\text { fazèje, bet tik iš anksto paveikus rent- } \\
\text { geno spinduliais }\end{array}$ \\
\hline $\begin{array}{l}45 \text { ir nuo } 450 \\
\text { iki } 3500\end{array}$ & $\begin{array}{l}\text { Escherichia coli } \\
\text { (Ji, et al., 2009) }\end{array}$ & $\begin{array}{l}\text { Lastelių gyvybingumas ir kolonijas for- } \\
\text { muojantys vienetai (CFU) sumažejo po } \\
\text { ilgesnio poveikio }\end{array}$ \\
\hline 6 & $\begin{array}{l}\text { HL60 (žmogaus promielo- } \\
\text { citinès leukemijos ląstelių } \\
\text { linija) } \\
\text { (Teodori, } \text { et al., 2002) }\end{array}$ & $\begin{array}{l}\text { SMF poveikis neturèjo itakos ląstelių } \\
\text { gyvybingumui }\end{array}$ \\
\hline $\begin{array}{l}100,500 \\
1000\end{array}$ & $\begin{array}{l}\text { Alternaria alternata } \\
\text { Curvularia inaequalis } \\
\text { Fusarium oxysporum } \\
\text { (Nagy, et al., 2004) }\end{array}$ & $\begin{array}{l}\text { Konidijų augimas padidèjo } 68 \%-33 \% \text {, } \\
\text { palyginti su Alternaria alternata ir Cur- } \\
\text { vularia inaequalis. }\end{array}$ \\
\hline
\end{tabular}


Kaip matoma iš 1.1 lentelès biologiniams eksperimentams dažniausiai naudojamas mT eilès magnetinis laukas.

\subsection{Stiprių impulsinių elektromagnetinių laukų taikymai biotechnologijoje}

Per paskutinị dešimtmetị buvo pasiūlytas bekontaktis metodas, grịstas stipriais impulsiniais magnetiniais laukais, skirtas grižtamajam ir negrịžtamajam biologinių ląstelių membranos pralaidumo valdymui (permeabilizavimui) (Kardos et al., 2016; Kranjc et al., 2016). Veikiant ląsteles impulsiniais kelių teslų magnetiniais laukais, jų membrana tampa laidi fluorescencinèms žymenims (Towhidi et al., 2012). Metodas galètų būti naudojamas kaip alternatyva elektroporacijai, kur naudojami impulsiniai elektriniai laukai membranu pralaidumui pakeisti (Kotnik et al., 2015; Yarmush et. al., 2014). Šiuo metu manoma, kad impulsinis magnetinis laukas indukuoja elektrinį lauką ir tokiu būdu poliarizuoja ląstelès membraną, kas įtakoja porų formavimą panašiai kaip elektroporacijoje (Kranjc et al., 2016; Towhidi et al., 2012). Tačiau, greitai kintančio magnetinio lauko indukuotas elektrinis laukas yra keliomis eilèmis mažesnis nei elektroporacijai reikalingas elektrinis laukas (Lucinskis et al., 2014; V. Novickij, Dermol, et al., 2017; V. Novickij, Grainys, Lastauskiene, et al., 2016). Dèl to, taip pat svarstomi kiti įtakojantys reiškiniai, tokie kaip elektroforezè (Schoenbach et al., 2015), ląstelių receptoriu aktyvavimas (Shankayi et al., 2014), elektroendocitozè (Ben-Dov et al., 2012) ar magnetomotorinès jègos (Yao et al., 2014), nors vis dar neịmanoma vienareikšmiškai nustatyti poveikio mechanizmo. Taip pat nustatyta, kad pavieniai impulsai iki 16,4 T nesukelia aptinkamų ląstelių pralaidumo valdymų (permeabilizacijos). Tačiau pritaikius 2,9 T impulsus (bet didesnio $\mathrm{d} B / \mathrm{d} t$ ), atsiranda ląstelių atsakas (V. Novickij, Grainys, 2015; Shankayi et al., 2013; Towhidi et al., 2012). Manoma, kad mažas ląstelių permeabilizacijos efektyvumas buvo dèl mažo indukuoto elektrinio lauko, kuris visais atvejais buvo žemiau $1 \mathrm{kV} / \mathrm{cm}$.

Tuomet didelio intensyvumo impulsiniai elektriniai laukai yra naudojami biologinių objektų veikimo tyrimams (Bhawandeep et al., 2017; Rems, Miklavčič, et al., 2016; Yarmush et al., 2014). Jau ištirti elektroporacijos metodai apima platų pritaikymą biotechnologijose, maisto perdirbime ir biomedicinoje, įskaitant klinikinę praktiką (Calvet, Mir, et al., 2016; Golberg et al., 2016; Kotnik et al., 2015; Lambricht et al., 2016; Yarmush et al., 2014). Nustatyta, kad procedūros yra saugios ir veiksmingos žmonèms, ir galimos naudoti gydimui piktybinių kepenų, kasos, plaučių, limfmazgiu ir kitų organų augliams (Jiang et al., 2015; Kluger et al., 2016; Scheffer et al., 2014). Nepaisant to, elektroporacijos metodas turi tam tikrų ribojančiu veiksnių, tokių kaip nuo bioimpedanso priklausomas elektrinio lauko pasiskirstymas (Neal et al., 2012), itampos iškraipymai 
(Guenther et al., 2015), nuo naviko dydžio priklausantis gydymo efektyvumas (Muratori et al., 2016), sudètingas elektrodų padèties nustatymas esant giliems navikams (Langus et al., 2016), elektrocheminès reakcijos elektrodo sąsajose (Bhonsle et al., 2015; Miklavčič et al., 2014; Rodaite-Riseviciene et al., 2014). Dèl to atsiranda alternatyvių metodų, tokių kaip neterminis šaltos plazmos gydymas ar sonoporacija, leidžiantys pagerinti priešvěžinio gydymo efektyvumą konkrečioje taikymo srityje (Amini, et al., 2016; Guerrero-Preston et al., 2014; Tamošiūnas et al., 2016; Timmermans et al., 2014). Todèl, viena iš tokių alternatyvų, gali būti impulsiniai magnetiniai laukai, kurie gali sukelti padidintą ląstelių membranų pralaidumą vaistams ar kitoms molekulėms (Kardos et al., 2016; Kranjc et al., 2016; V. Novickij, Grainys, Butkus, et al., 2016; Towhidi et al., 2012). Magnetoporacija buvo patvirtinta in vivo įterpiant žaliają fluorescencinę plazmidę ị raumenį (Kardos et al., 2016) ar cisplatiną ị navikus (Kranjc et al., 2016), todèl įvertinant poveikị ląstelëms galima palyginti su ịprastine elektroporacija. In vitro tyrimai, kuriuose nagrinejama magnetoporacijos metodika, taip pat ịrodo, kad ịmanoma pasiekti ląstelių pralaidumo valdymą (permeabilizaciją). Tačiau gydymo efektyvumas yra kelis kartus mažesnis, palyginti su elektroporacija (Firoozabadi et al., 2015; V. Novickij, Grainys, Lastauskienè, et al., 2015; Towhidi et al., 2012). Buvo nustatyta, kad indukuotas elektrinis laukas negali būti laikomas vieninteliu parametru, atsakingu už membranos pralaidumą magnetoporacijos metu (V. Novickij et al., 2016).

Remiantis esamais tyrimais, mikrosekundinès trukmès magnetiniai impulsai su stačiais frontais yra labiau pritaikomi magnetoporacijoje bei atsiranda poreikis kurti didelio $\mathrm{d} B / \mathrm{d} t$ magnetinio lauko sistemas (Kardos et al., 2016; V. Novickij, Dermol, et al., 2017; V. Novickij, Girkontaite, et al., 2017; Towhidi et al., 2012).

\subsection{Itaisai naudojami stipraus magnetinio lauko generatoriuose}

Stiprių magnetinių laukų generavimas reikalauja kA eilès srovių, tačiau tai sukuria inžinerines ir technologines problemas formuojant didelès galios impulsus. Tokiam impulsui formuoti reikia įtaisų - raktų galinčių sukomutuoti visą kondensatoriuose sukauptą energiją $\mathfrak{i}$ apkrovą (magnetoporacijos atveju $\mathfrak{i}$ induktoriu). Magnetoporacijoje tokių raktų $\mathrm{d} V / \mathrm{d} t$ ir $\mathrm{d} I / \mathrm{d} t$ turi būti pakankamai didelis (Hulangamuwa et al., 2020), kad galima būtų užtikrinti pakankamą elektrinio lauko indukciją. Raktai gali būti skirstomi ị dielektrinio pramušimo ar puslaidininkinius (Vechalapu, et al., 2016). Vieni paprasčiausių raktų yra kibirkštikliai (angl. spark gap - dielektrinio pramušimo raktai), kurie naudojami nuosekliai sujungti su apkrova ir susideda iš dviejų ir daugiau elektrodų bei dielektriko (1.1 pav.) (Jerzy, 2020). 


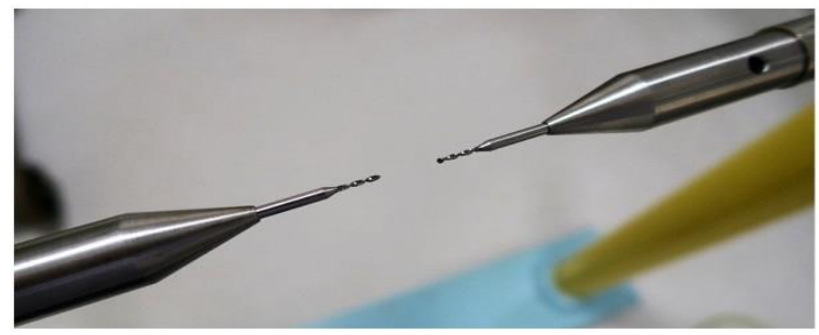

1.1 pav. Elektrodai su oro tarpu (Jerzy, 2020)

Fig. 1.1. Electrodes with air gap (Jerzy, 2020)

Pasiekus ribinę pramušimo įtampą dielektrikas esantis tarp elektrodų yra pramušamas, susiformuojant plazmai kibirkštikliai gali praleisti kA eilès sroves ir komutuoti ịtampas iki dešimčių kV. Todèl kibirštikliai gali būti naudojami ịvairiose generatorių topologijose: Markso, Bloumlein ar kombinuotose grandinèse (Beyer, et al., 2004; Ponniran et al., 2016; Rose et al., 2017). Dielektrinio pramušimo raktai yra keičiami puslaidininkine technologija, nes yra neatsparūs korozijai, ir tokie raktai taip pat praranda savo valdymo/komutavimo savybes (Achour et al., 2018; Achour, et al., 2017). Kibirkštikliais grịstos sistemos turi ribotas impulsų parametrų valdymo galimybes, t. y. negalima valdyti trukmės ir/ar amplitudès, arba yra apribotas impulsų pasikartojimo dažnis.

Puslaidininkiniai raktai gali išspręsti problemas susijusias su impulsų pasikartojimo dažniu ar ne ilgaamžiškumu, kuris yra tipinis dielektrinio pramušimo raktams, tačiau atsiranda apribojimai komutuojamos srovès ir ịtampos dydžiams (Liu et al., 2019; Yasu et al., 2017). Dèl šios priežasties stiprių magnetinių laukų generavimui dažniausiai naudojami tiristoriai, dèl kilo amperų eilès srovès palaikymo (Grainys et al., 2015), tačiau dèl mažo $\mathrm{d} I / \mathrm{d} t$ (tipiškai iki kelių šimtų $\mathrm{A} / \mu \mathrm{s}$ ) šio tipo raktai turi ribotą pritaikymą aukšto $\mathrm{d} B / \mathrm{d} t$ magnetinio lauko sistemoms. IGBT ir MOSFET raktų pritaikomumas yra apribotas mažos komutuojamos galios, ką galima išspręsti jungiant nuosekliai/lygiagrečiai raktus ir masyvus (V. Novickij, Grainys, et al., 2014; V. Novickij, Grainys, et al., 2017).

Ivertinant šio darbo specifiką, reikia rinktis raktus atsižvelgiant ị komutuojamą galią, raktų valdymo lankstumą ir ilgaamžiškumą. Šiam tikslui gali tikti ignitronai - gyvsidabrio pripildytos lempos su valdymo elektrodu. Tokie raktai gali komutuoti iki šimtų kV ịtampas ir šimtų kA srovès, užtikrindami didesnị ilgaamžiškumą negu dujiniai kibirkštikliai. Puslaidininkinių raktų pavyzdžiai ir jų parametrai yra pateikti 1.2 lentelëje.

Sroves esančias kA ir kelių kV ịtampas užtikrina tiristorių puslaidininkinè technologija arba dielektrinio pramušimo raktai (kibirkštikliai, ignitronai). Taip pat ịvertinant magnetoporacijos metodikos naujumą, gaunama išvada, kad reikia išbandyti visus tinkamus raktų tipus. 
1.2 lentelè. Tipinių impulsų formavimo raktų parametrų palyginimas

Table 1.2. Typical characteristics of pulse forming switches

\begin{tabular}{|c|c|c|c|c|c|}
\hline Raktas & Modelis & Itampa & $\begin{array}{l}\text { Srovès } \\
\text { stipris }\end{array}$ & $\mathrm{t}_{\mathrm{r}}$ & $\mathrm{t}_{\mathrm{f}}$ \\
\hline \multirow{4}{*}{ IGBT } & $\begin{array}{l}\text { IXGH32N170 (Mwaniki, et } \\
\text { al., 2019) }\end{array}$ & $1,7 \mathrm{kV}$ & $75 \mathrm{~A}$ & $42 \mathrm{~ns}$ & $\begin{array}{c}560 \\
\text { ns }\end{array}$ \\
\hline & $\begin{array}{l}\text { AUIRGPS4070D0 (Rashitov } \\
\text { et al., 2019) }\end{array}$ & $0,6 \mathrm{kV}$ & $240 \mathrm{~A}$ & $110 \mathrm{~ns}$ & $\begin{array}{c}125 \\
\mathrm{~ns}\end{array}$ \\
\hline & $\begin{array}{l}\text { CM600HA-24A (Moonesan } \\
\text { et al., 2011) }\end{array}$ & $1,2 \mathrm{kV}$ & $600 \mathrm{~A}$ & $190 \mathrm{~ns}$ & $\begin{array}{c}350 \\
\mathrm{~ns}\end{array}$ \\
\hline & $\begin{array}{l}\text { FZ3600R17HP4B2BOSA2 } \\
\text { (Modul, et al., 2013) }\end{array}$ & $1,7 \mathrm{kV}$ & $3,6 \mathrm{kA}$ & $290 \mathrm{~ns}$ & $\begin{array}{c}315 \\
\mathrm{~ns}\end{array}$ \\
\hline \multirow{4}{*}{ MOSFET } & $\begin{array}{l}\text { C2M0045170D (El-Helw } \\
\text { et al., 2018) }\end{array}$ & $1,7 \mathrm{kV}$ & $72 \mathrm{~A}$ & $20 \mathrm{~ns}$ & $18 \mathrm{~ns}$ \\
\hline & $\begin{array}{l}\text { STY145N65M5 (Abbatelli } \\
\text { et al., 2018) }\end{array}$ & $0,65 \mathrm{kV}$ & $138 \mathrm{~A}$ & $11 \mathrm{~ns}$ & $82 \mathrm{~ns}$ \\
\hline & $\begin{array}{l}\text { CAS300M17BM2 } \\
\text { (Rabkowski, et al., 2015; } \\
\text { Zhang et al., 2017) }\end{array}$ & $1,7 \mathrm{kV}$ & $325 \mathrm{~A}$ & $72 \mathrm{~ns}$ & $56 \mathrm{~ns}$ \\
\hline & $\begin{array}{l}\text { CAS325M12HM2 (McNutt } \\
\text { et al., 2018) }\end{array}$ & $1,2 \mathrm{kV}$ & $444 \mathrm{~A}$ & $35 \mathrm{~ns}$ & $29 \mathrm{~ns}$ \\
\hline \multirow{3}{*}{ Tiristoriai } & $\begin{array}{l}\text { DCR3980H85 (Dynex, } \\
\text { et al., 2013) }\end{array}$ & $8,5 \mathrm{kV}$ & $\begin{array}{c}59,58 \\
\mathrm{kA}\end{array}$ & \multicolumn{2}{|c|}{$\begin{array}{l}\mathrm{d} V / \mathrm{d} t 2000 \mathrm{~V} / \mu \mathrm{s} \\
\mathrm{d} I / \mathrm{d} t 200 \mathrm{~A} / \mu \mathrm{s}\end{array}$} \\
\hline & $\begin{array}{l}\text { TZ240N36KOFHPSA1 } \\
\text { (Eigenschaften, } \text { et al., 2010) }\end{array}$ & $3,6 \mathrm{kV}$ & $700 \mathrm{~A}$ & \multicolumn{2}{|c|}{$\begin{array}{l}\mathrm{d} V / \mathrm{d} t 100 \mathrm{~V} / \mu \mathrm{s} \\
\mathrm{d} I / \mathrm{d} t 100 \mathrm{~A} / \mu \mathrm{s}\end{array}$} \\
\hline & $\begin{array}{l}\text { T9G0121203DH (Dunlea } \\
\text { et al., 2019) }\end{array}$ & $1,2 \mathrm{kV}$ & $\begin{array}{l}1,88 \\
\mathrm{kA}\end{array}$ & \multicolumn{2}{|c|}{$\begin{array}{c}\mathrm{d} V / \mathrm{d} t 2400 \mathrm{~V} / \mu \mathrm{s} \\
\mathrm{d} / / \mathrm{d} t 150 \mathrm{~A} / \mu \mathrm{s}\end{array}$} \\
\hline \multirow[b]{2}{*}{ Kibirkštiklis } & $\begin{array}{l}\text { IEBA (angl. intense } \\
\text { electron-beam accelerator) } \\
\text { (Cheng } \text { et al., 2009) }\end{array}$ & $360 \mathrm{kV}$ & $32 \mathrm{kA}$ & $60 \mathrm{~ns}$ & $\begin{array}{c}120 \\
\mathrm{~ns}\end{array}$ \\
\hline & $\begin{array}{l}\text { HVHCS (angl. arc- } \\
\text { quenching chambers of high- } \\
\text { voltage high-current swit- } \\
\text { ches) (Budin et al., 2017) }\end{array}$ & $1,5 \mathrm{kV}$ & $70 \mathrm{kA}$ & $400 \mu \mathrm{s}$ & $\begin{array}{c}600 \\
\mu \mathrm{s}\end{array}$ \\
\hline \multirow{2}{*}{ Ignitronas } & $\begin{array}{l}\text { NL-1057 (Giesselmann, } \\
\text { et al., 1993) }\end{array}$ & $25 \mathrm{kV}$ & $300 \mathrm{kA}$ & $4,5 \mathrm{~ms}$ & $4 \mathrm{~ms}$ \\
\hline & $\begin{array}{l}\text { NL7703EHV(Kumar, et al., } \\
\text { 2018) }\end{array}$ & $50 \mathrm{kV}$ & $100 \mathrm{kA}$ & $5 \mu \mathrm{s}$ & $15 \mu \mathrm{s}$ \\
\hline
\end{tabular}

Tačiau, magnetinio lauko generavimui taip pat reikalingi impulsiniai induktoriai (ritès), o lauko homogeniškumas ir atitinkamai poveikio parametrai priklauso nuo ritès geometrijos. Ivertinant, kad biologiniams eksperimentams reikalingas iki kelių $\mathrm{ml}$ tūris, geriausia naudoti solenoido tipo daugiasluoksnes rites 
(Lucinskis et al., 2014). Tokių ričių (1.2 pav.) sukuriamas magnetinis laukas priklauso nuo ritès apvijų, sluoksnių skaičiaus ir apvijos dydžio (J. Novickij et al., 2004).

Komutuojant kilo amperų eilès srovès impulsus per tokio tipo induktorius, dèl Lorenco jègos, atsiranda deformacijos tarp apvijų (Bartkevičius \& Novickij, 2008). Todèl siekiant sutvirtinti apvijas, visas korpusas patalpinamas ị metalinị šarvą. Apvijų izoliavimui naudojamos kompozitinès medžiagos, pavyzdžiui stiklo-epoksido pluošto kompozitinė medžiaga, o apvijų sutvirtinimui Zylon, Kapton, S2 stiklo pluoštas (Bartkevičius \& Novickij, 2008; Ka, et al., 2009).

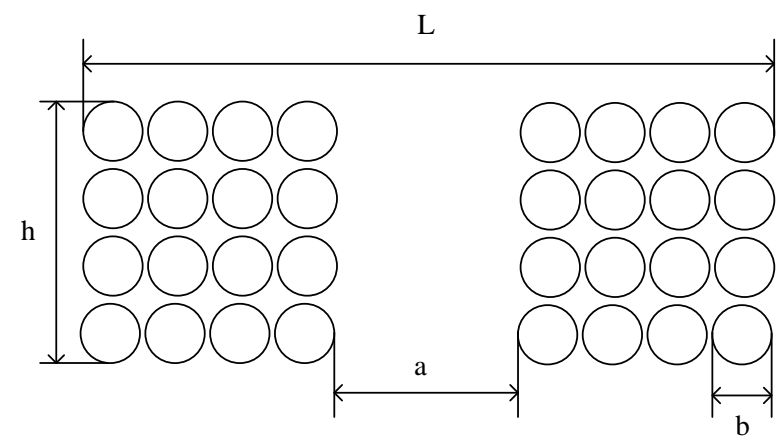

1.2 pav. Daugiasluoksnis induktorius

Fig. 1.2. Multilayered inductor

Vienas iš pagrindinių neigiamų faktorių, komutuojant kilo amperų eilès sroves yra Džaulio šiluma atsirandanti apvijose ir galinti paveikti biologinius mėginius. (V. Novickij, Grainys, Švediene, et al., 2014). Dėl šios priežasties šilimas magnetoporacijos eksperimentuose privalo būti ribojamas, kuriant aktyvias aušinimo sistemas ir/ar didelio tūrio induktorius, užtikrinant efektyvią/pasyvią oro konvekciją ir/arba didelį šiluminių mainų inertiškumą. Bet kuriuo atveju, biologiniams eksperimentams bandinio temperatūra privalo būti apribota fiziologinių temperatūrų ruože (iki $37{ }^{\circ} \mathrm{C}$ ) viso impulsinio poveikio metu.

Galiausiai impulsinių induktorių struktūra apriboja ir ịtakoja ne tik patị bandini, bet ir kuriamo magnetinio lauko parametrus. Priklausomai nuo induktyvumo keičiasi visos impulsinès grandinès apkrova, o dominuojant reaktyviajai komponentei gali atsirasti nevaldomi pereinamieji procesai (V. Novickij et al., 2015). O esant, dideliems svyravimas atsiranda didelè tikimybė sugadinti puslaidininkini raktą, o magnetoporacijos kontekste tampa sudètinga interpretuoti poveikio priklausomybes nuo impulso parametrų. Norint, slopinti parazitinio ir apkrovos ritès induktyvumų ịtaką didelès galios grandinèse, naudojamos pereinamuju procesų kompensavimo grandinès (angl. snubber circuits) (Staigvila, et al., 2019). 
Pereinamujų procesų kompensavimas priklauso nuo sukauptos energijos dydžio apkrovoje ir rakto greitaveikos, kurios pagalba komutuojama energija (Delshad et al., 2017). Didèlès galios impulsų generatoriuose dominuoja dviejų tipu grandinès: 1) kirtiklio grandinès lygiagrečiai apkrovai ir 2) RC, RCL, RCD grandinès lygiagrečiai raktui (Staigvila, et al., 2018).

Kirtiklio (angl. crowbar) grandinès naudojamos impulsų fronto kritimo laiko formavimo tikslais ir apriboti raktų viršitampius dèl atgalinių srovių (Pawar \& Patil, 2016; Yang et al., 2016). Paprasčiausia pasyvinè kirtiklio grandinè (1.3 pav.) sudaryta iš didelès galios diodo ir nuosekliai sujungtos varžos, kurie yra jungiami lygiagrečiai apkrovai (Tang et al., 2018). Induktyviojoje didelès galios grandinejje impulso metu sukuriama atvirkštinè ịtampa (Dong et al., 2016), dẻl ko gali būti neigiamai perkraunamas kondensatorius ir/ar susidarantys viršitampiai ant puslaidininkinio rakto.

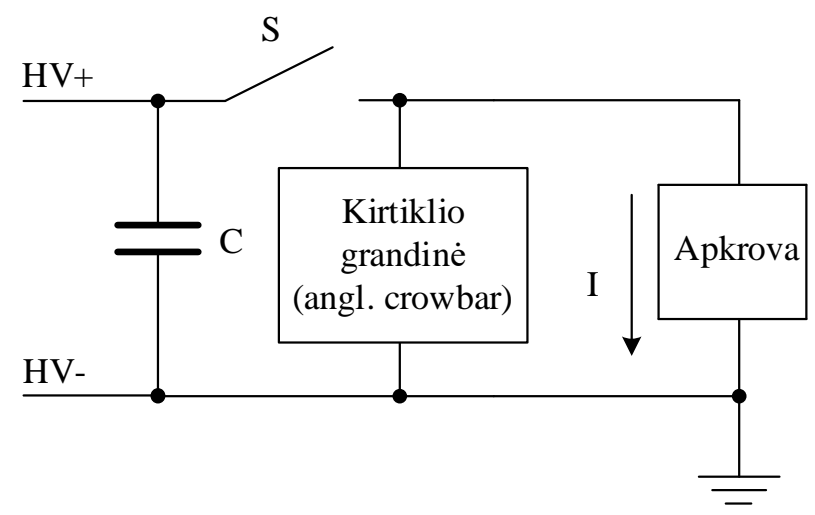

1.3 pav. Kirtiklio grandinè

Fig. 1.3. Crowbar circuit

Kirtiklio grandinė sukuria atskirą kontūrą, kuris išspinduliuoja induktyvumo sukauptą energiją. Atitinkamai sumažèja pereinamųjų procesų įtaka (Arias \& Nunes, 2017; Jayanthi \& Devaraj, 2019; Rihan, 2018; Wang et al., 2019).

Papildomai rakto apsaugai gali būti naudojamos RC, RCD ar RCL grandinès, kurios pavyzdys pavaizduotas 1.4 paveiksle. 


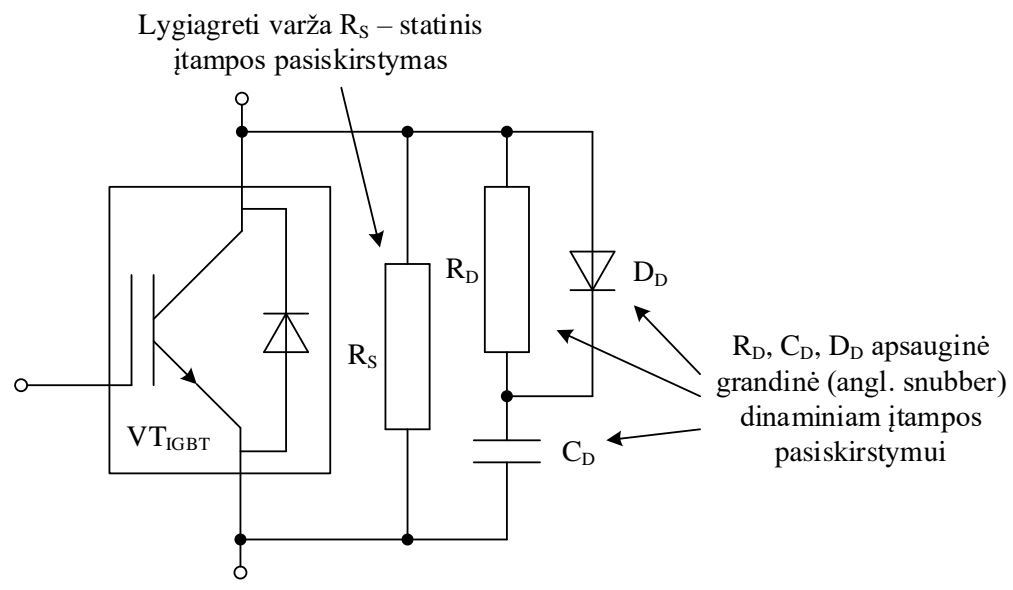

1.4 pav. Apsauginè pereinamujų procesų kompensavimo grandinė

Fig. 1.4. Protectional transient process compensation circuit

Tokio tipo grandinès yra ypatingai paplitusios, kadangi leidžia valdyti impulsų $\mathrm{d} / / \mathrm{d} t$ ir $\mathrm{d} V / \mathrm{d} t$ (F. Liu et al., 2017; Yatsugi et al., 2018). Išskirtiniais atvejais, gali būti naudojama modifikuota su papildomu induktyvumu (RCL), padidinat apsaugos grandinės efektyvumą ribojant srovę (Merz \& Grimes, 2012).

\subsection{Esamos magnetinio lauko generatorių technologijos}

Šiame poskyryje apžvelgiami paskutinių metu impulsinių elektromagnetinių laukų generatorių pavyzdžiai, kurie yra taikomi eksperimentuose su biologiniais objektais.

Dauguma darbų naudoja dvipolių impulsų sistemas taikomiesiems tyrimams elektromagnetiniuose laukuose, tuo tarpu vienas iš populiarių būdų generuoti dvipolius impulsus yra $\mathrm{H}$-topologija, kuri taikoma ir impulsinių magnetinių sistemų srityje (Elserougi et al., 2016). Xiong et al. 2018 metais pasiūlè magnetinio lauko generatorių, kuri sudaro $\mathrm{VT}_{1}, \ldots, \mathrm{VT}_{8}$ puslaidininkiniai MOSFET raktai, valdomi mikrovaldikliu naudojant impulso pločio moduliaciją PWM (angl. pulsed width modulation) pateikta 1.5 paveiksle. Kai $\mathrm{VT}_{5}$ ir $\mathrm{VT}_{6}$ raktai atidaryti, tuomet sudaromas RLC grandinès kontūras, kuris sudarytas iš energijos kaupimo kondensatoriaus $\mathrm{C}_{1}$, ritès $\mathrm{L}_{1}$ ir šunto varžos $\mathrm{R}_{2}$. Kai kondensatorius yra nepakankamai įkrautas, energija iš ritès $L_{1}$ kaupiama kondensatoriuje $C_{1}$. Tokiu būdu energija gali būti naudojama pakartotinai. 


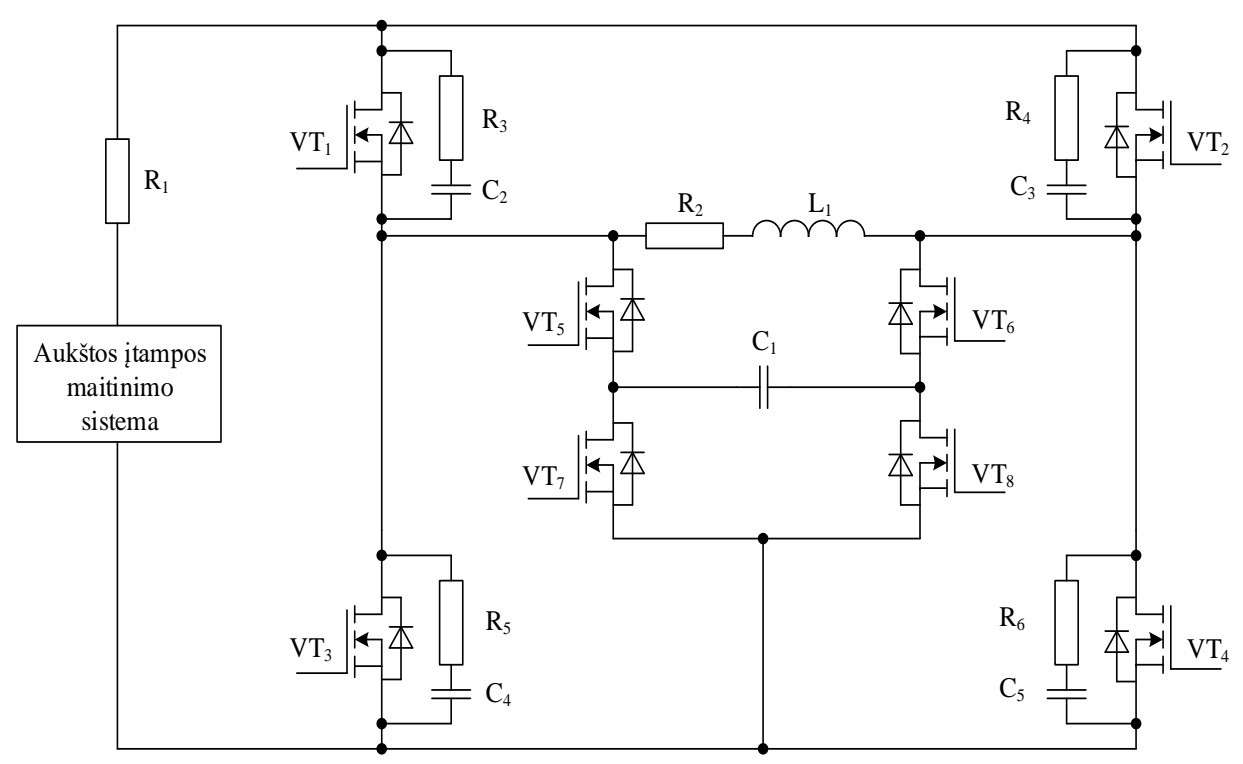

1.5 pav. H topologijos magnetinio lauko generatoriaus schema

(Xiong et al., 2018)

Fig. 1.5. Circuit of $\mathrm{H}$ topology magnetic field generator

(Xiong et al., 2018)

Kai raktai $\mathrm{VT}_{1}, \mathrm{VT}_{6}$, ir $\mathrm{VT}_{7}$ yra atidaryti, srovė teka per $\mathrm{RLC}$ grandinę. Tuo pačiu metu, kondensatorius $\mathrm{C}_{1}$ yra ịkraunamas. Itampai kondensatoriuje pasiekus maksimalią reikšmę srovè ritèje nukrenta iki 0 A, o energija sukaupta kondensatoriuje $\mathrm{C}_{1}$ gali būti panaudota dar kartą.

Kai raktai $\mathrm{VT}_{2}, \mathrm{VT}_{6}$, ir $\mathrm{VT}_{7}$ yra atidaryti, susidaro kontūras tarp įtampos šaltinio ir kondensatoriaus. Energija kaupiama kondensatoriuje $\mathrm{C}_{1}$ ribojant srovę per $\mathrm{R}_{1}$ varžą. Tuo tarpu, kai raktai $\mathrm{VT}_{1}$, ir $\mathrm{VT}_{2}$ yra uždaryti, o raktai $\mathrm{VT}_{5}, \mathrm{VT}_{6}$, atidaryti, sudaromas RLC kontūras ir sukaupta energija kondensatoriuje $\mathrm{C}_{1}$ iškraunama riteje $\mathrm{L}_{1}$. Tokio tipo generatorius gali sukurti 130 A srovès ir $70 \mathrm{mT}$ magnetini lauką (Xiong et al., 2018).

Matoma, kad nors pasiūlytas generatorius turi pakankamą lankstumą reguliuojant impulsų trukmę, tačiau dẻl ribotos galios jis negali būti naudojamas magnetoporacijos srityje ir yra apribotas tiriant silpnų elektromagnetinių laukų poveikị biologiniams objektams. Tokio tipo generatoriai dažnai yra pritaikomi nervų stimuliacijai, pavyzdžiui, transkrajininei magnetinei stimuliacijai TMS (angl. transcranial magnetic stimulation).

Impulsinio magnetinio lauko generatoriaus pavyzdys, kuris yra skirtas transkrajininei magnetinei stimuliacijai yra pavaizduotas 1.6 paveiksle. 


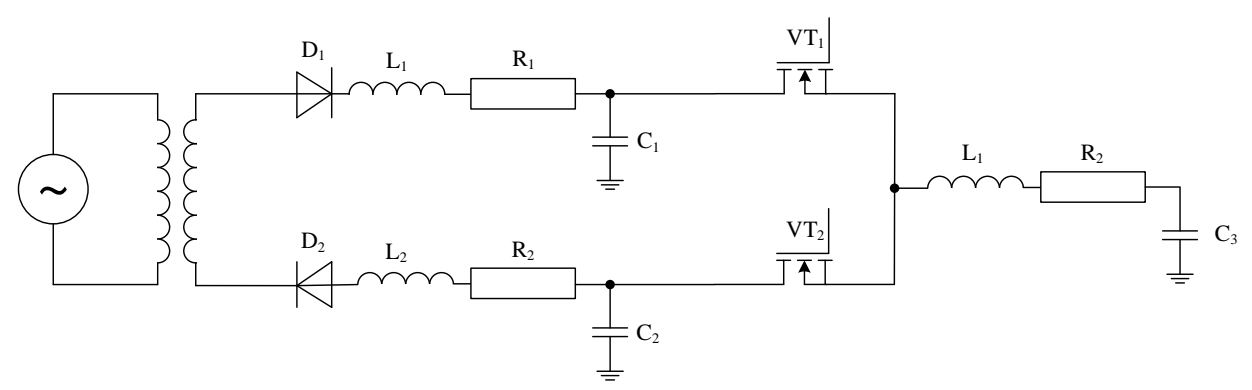

1.6 pav. Magnetinio lauko generatoriaus schema transkrajininei magnetinei stimuliacijai (Bouda et al., 2014)

Fig. 1.6. Magnetic field generator circuit for transcranial magnetic stimulation

(Bouda et al., 2014)

Dažniausiai šioje srityje naudojamos vienfazès ir dvifazės signalų formos. Dvifazị impulsą galima sukurti keliais būdais: kaip ir buvo minèta anksčiau, naudojant pilną H-tiltelio ir modifikuoto H-tiltelio metodus. Šiuo atveju naudojami du MOSFET raktai su atskirais valdikliais. Sistema gali būti padalinta ị keletą posistemių: galios šaltinis, energijos kaupiklis, užtūros valdymo grandinè ir apkrova. Galios šaltinio pagalba kondensatorius $C_{1}$ yra įkraunamas teigiama įtampa, o kondensatorius $\mathrm{C}_{2}$ įkraunamas neigiama ịtampa. Per TMS impulsą apkrovos ritė $\mathrm{L}$ yra prijungta prie vieno iš dviejų energijos kaupiklių $\mathrm{C}_{1}$ ir $\mathrm{C}_{2}$ atitinkamai naudojant MOSFET raktus. Prietaisą galima valdyti išjungiant ir ijungiant $\mathrm{VT}_{1}$ ir $\mathrm{VT}_{2}$ raktus. Magnetinis laukas sukuriamas riteje yra proporcingas srovei tekančiai per ritę $\mathrm{L}$.

Bouda et al. 2014 pasiūlytoje sistemoje $\mathrm{C}_{1}$ ir $\mathrm{C}_{2}$ yra ịkraunami galios šaltinio per $D_{1}$ ir $D_{2}$ lyginimo grandine sujungta su $115 \mathrm{~V}_{\mathrm{ac}}$ maitinimo šaltiniu. Dèl ịžeminimo problemų nenaudojama pilno lyginimo tiltelio schema. Prietaisas suprojektuotas su dviem vienodais kondensatoriais $\mathrm{C}_{1}=\mathrm{C}_{2}=24600 \mu \mathrm{F}$ ir $100 \mathrm{~V}$ itampos naudojimo riba. Valdymo grandinejje naudojamas transformatorius (1:1) galvaniniam atrišimui. Mikrovaldiklis sugeneruoja stačiakampi impulsą pirminejje apvijoje, o antrinè apvija prijungta MOSFET raktams $\left(\mathrm{VT}_{1}\right.$ ir $\left.\mathrm{VT}_{2}\right)$ valdyti.

Generatoriai skirti TMS nèra visiškai suderinami su magnetoporacija ir šiame etape netgi $>3$ T TMS sistemos netinka indukuoti plazminès membranos padidintą pralaidumą in vitro, bet in vivo buvo gauti teigiami rezultatai (Brezar et al., 2020; Kardos \& Rabussay, 2012; Kranjc et al., 2016). Manoma, kad poveikio nebūvimas in vitro yra ịtakojamas nepakankamo tokių sistemų $\mathrm{d} B / \mathrm{d} t$.

Viena pirmujų sistemų, kurios tinka in vitro magnetoporacijai pasiūlè Van Bree et al. 2013. Sistema sudaryta iš galios grandinès (maitinimo šaltinis, kondensatoriai, dielekrinio pramušimo rakto), kurie sudaro kontūrą su vienos apvijos kilpa (1.7 pav.). 


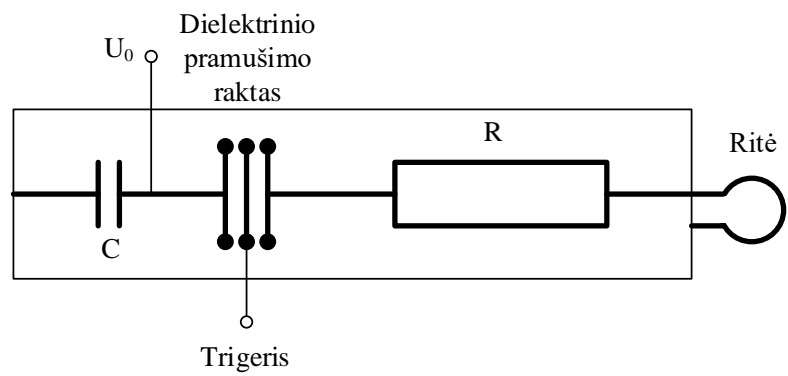

1.7 pav. Principine didelio $\mathrm{d} B / \mathrm{d} t$ generatoriaus schema (Van Bree et al., 2013)

Fig. 1.7. Principle circuit of high $\mathrm{d} B / \mathrm{d} t$ generator (Van Bree et al., 2013)

Srove vienos vijos kilpoje sugeneruojama nuosekliai sujungta RLC grandine, kur kondensatorius $\mathrm{C}$ ịkraunamas DC itampa $\mathrm{U}_{0}$. Kilpoje indukuotas elektrinis laukas priklauso nuo impulso fronto laiko, srovès dydžio kilpoje, srovę ribojančios varžos $\mathrm{R}=50 \Omega$ ir vidinio grandinès induktyvumo L. Naudojant Kirhofo itampos dèsnis RLC grandinèje, srovei i $(t)$ gali būti pritaikyti trys sprendimai: kai $R^{2}<\frac{4 L}{C}$ (angl. under damped), $R^{2}>\frac{4 L}{C}$ (angl. over damped), $R^{2}=\frac{4 L}{C}$ (angl. critically damped)(Elgenedy et al., 2018). Daugiapakopis dielektrinio pramušimo raktas pasirinktas sumažinti rakto atsidarymo laiką. Grandinès vidinis induktyvumas yra laikomas mažas ir nesiekia $80 \mathrm{nH}$, o pati sistema suprojektuota taip, kad kondensatoriai yra kuo arčiau vienas kito.

Kilpa suprojektuota taip, kad galima būtų patalpinti ml eilès mėgintuvèlị su ląstelèmis. Didžiausia generatoriaus palaikoma srovė yra $1250 \mathrm{~A}$, o impulso fronto laikas siekia tik $5 \mathrm{~ns}$, todèl $\mathrm{d} / / \mathrm{d} t$ yra $\sim 250 \mathrm{~A} / \mathrm{ns}$. Pagal autorių skaičiavimus, tai atitinka didžiausią elektrinị lauką iki $10 \mathrm{kV} / \mathrm{cm}$.

Kita grandinių topologija, kuri tinka stiprių magnetinių laukų generavimui yra modulinè ir dažnai taikoma ịvairiose galios elektronikos srityse, t. y. Markso generatoriaus topologija.

Markso topologijos generatorius sudaromas iš vienodų pakopų. Pakopas sudaro kondensatoriai ir raktai (dažnai dielektrinio pramušimo). İkrovimo būsenoje kondensatoriai yra įkraunami lygiagrečiai, o pasiekus įkrautą kritinę ịtampą (kuri priklauso nuo tarp elektrodų esančio tarpo dydžio) ịvyksta dielektrinis pramušimas dẻl kurio kondensatoriai susijungia nuosekliai ir sukauptą energiją iškraunama per apkrovą. Kadangi dielektrinio pramušimo raktai yra sunkiai valdomi ir turi ribotą veikimo ciklą, vis dažniau jie yra pakeičiami puslaidininkiniais. Tačiau, tokiu atveju atsiranda srovès ir ịtampos apribojimai bei gedimo rizika dèl pereinamujų procesų grandineje. Puslaidininkinio Markso generatoriaus pavyzdys yra pateiktas 1.8 paveiksle. (Redondo et al., 2018). 
Valdymo signalai kiekvienam MOSFET raktui generuojami atskirai kiekvienai pakopai, sinchronizuotas trigerio signalas siunčiamas iš impulsinio transformatoriaus. Šiame generatoriuje MOSFET raktai pasirinkti dèl greitaveikos, pakankamos raktų darbinès įtampos $900 \mathrm{~V}, 65 \mathrm{~m} \Omega$ vidinès varžos ir $90 \mathrm{~A}$ impulsinès srovès.
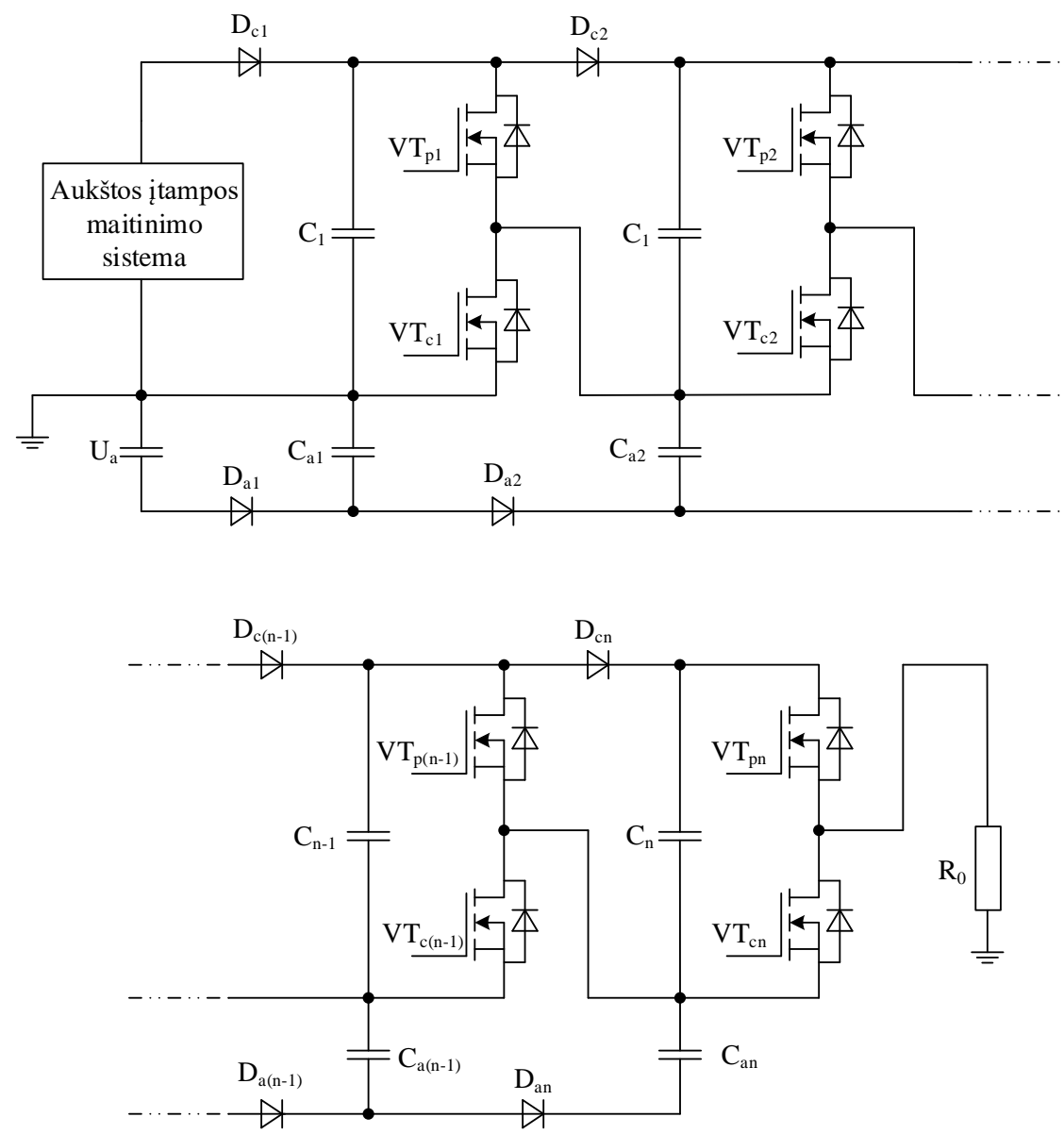

1.8 pav. Markso topologijos generatorius su puslaidininkiniais raktais (Redondo et al., 2018)

Fig. 1.8. Marx topology generator with semiconductor switches (Redondo et al., 2018)

Norint padidinti generuojamo impulso srovę pakopose naudojami raktai yra sujungiami lygiagrečiai. Redondo et al. 2019 pasiūlytoje sistemoje pakopose sujungiami 24 raktai lygiagrečiai, o naudojant 50 pakopų galima generuoti impulsus 
$40 \mathrm{kV}$ ir 3,2 kA sroves su kylančiu ir krentančiu impulso frontu, kurio trukmė yra tik 30 ns, o impulso plotis $3 \mu \mathrm{s}$. Tačiau, pasiūlytoje sistemoje naudojama varžinė apkrova. Magnetoporacijos tyrimuose apkrovoje yra dominuojanti induktyvioji komponentè (naudojamas induktorius). Atitinkamai grandinejje būtų indukuojamos atgalinès srovès ir ịtampos, o dešimčių raktų sinchronizavimas taptų pernelyg sudètingas. Galiausiai impulso frontas taip pat ženkliai padidètų dẻl RLC parametrų galios grandinèje, bet tai nereiškia, kad Markso generatoriaus topologija negali būti pritaikyta sub-mikrosekundinio fronto magnetinių impulsų generavimui. Ivvertinant, kad magnetoporacijos metodika tik pradeda vystytis, ypatingu reikalavimų impulsų parametrų lankstumui šiuo metu srityje nèra - svarbu indukuoti valdomą bekontakčią pernašą ląsteliniame lygyje. Dèl šios priežasties trumpų ir didelių $\mathrm{d} B / \mathrm{d} t$ impulsų generavimui gali tikti Markso generatoriaus topologija su dielektrinio pramušimo raktais.

Ivertinant, kad srovè tokiame generatoriuje siektų bent kelis kA, o impulsų skaičius vienam bandiniui gali būti šimtai, pagrindinis tokio generatoriaus trūkumas yra elektrodų korozija. Tokiu atveju arba nepavykus pasiekti reikiamų parametrų, galima būtų panaudoti Markso generatoriaus topologiją grịstą tiristoriniais raktais analogiškai grandinei, kuri buvo pasiūlyta Pecastaing et al., 2006. Grandinè pavaizduota 1.9 paveiksle.

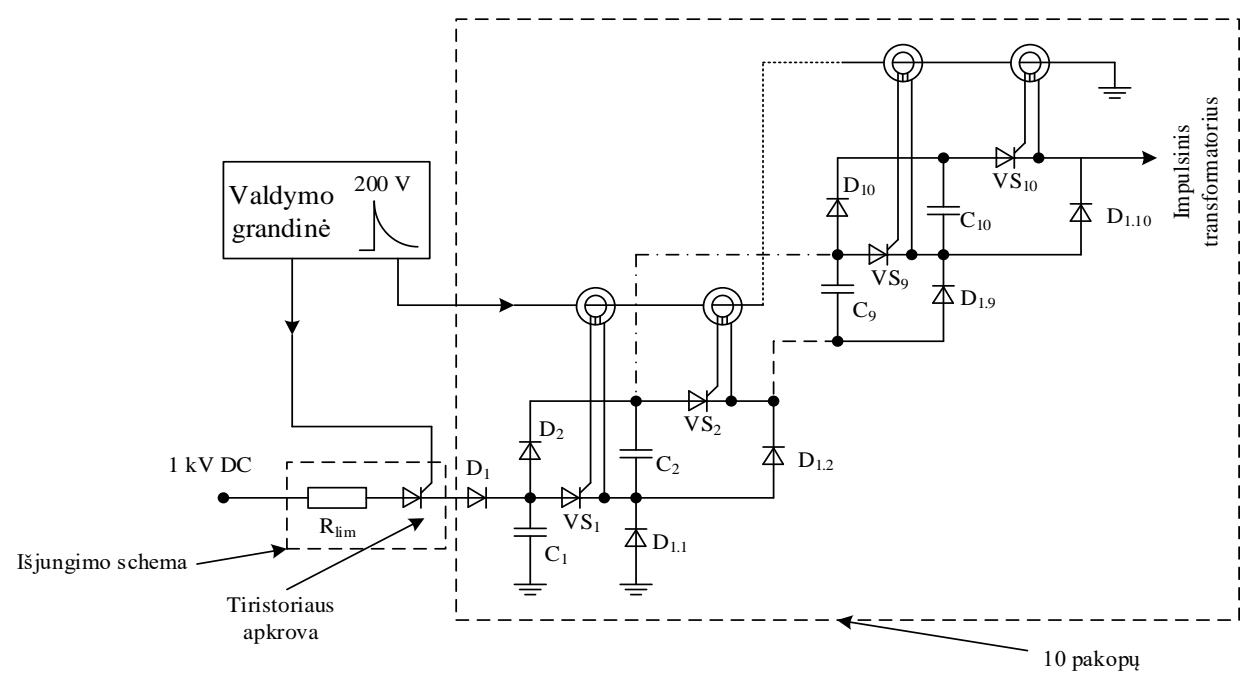

1.9 pav. Tiristorinis Markso topologijos generatorius su sinchronizuotu valdymu naudojant toroidinius transformatorius (Pécastaing et al., 2006)

Fig. 1.9. Thyristor-based Marx topology generator with synchronous control using toroid transformers (Pécastaing et al., 2006) 
Šiame generatoriuje energijos komutavimui naudojami tiristoriai iškrauti $6,6 \mathrm{kV}$ ịtampą. Kadangi kiekvieno tiristoriaus srovè turi būti apribota iki $75 \mathrm{~A}$, generatorius suprojektuotas taip, kad būtų sudarytas iš dviejų lygiagrečių Markso grandinès topologijų. Kiekvieną Markso generatorių sudaro dešimt pakopų, pakrautų iki $1 \mathrm{kV}$, su $22 \mathrm{nF}$ kondensatoriais kiekvienoje pakopoje (suminè kondensatorių talpa $-4,4 \mathrm{nF}$ ). Kiekvienoje pakopoje naudojami mažos galios tiristoriai. Abiejų generatorių dvidešimt tiristorių ijungiami tuo pačiu metu, kad būtų pasiektas pastovus ir santykinai greitas impulso frontas $(\approx 70 \mathrm{~ns})$. Kiekvienas tiristorius sujungtas su feritine šerdimi. Antrinè grandinè sujungta tarp tiristoriaus užtūros ir katodu, sudaryta iš kelių apvijų, o pirminejje grandinèje tik viena apvija. Tokia sistema užtikrina galvaninę izoliaciją tarp kiekvieno tiristoriaus ir tarp valdymo ir aukštos įtampos grandinès.

Taip pat ijungus tiristorių, jo valdyti negalima. Norint išjungti, anodo - katodo srovès vertè turi būti mažesnè už ribinę tiristoriaus užsidarymo srovę. Nurodytame pavyzdyje papildomai suprojektuota išjungimo grandinè, kurią sudaro „ $\mathrm{R}_{\lim }$ “ varža ir „,apkrovos tiristorius“. Šis tiristorius pirmiausia ijungiamas valdymo grandine, kad būtu galima pakrauti kondensatorius. Kai kiekvieno kondensatoriaus įtampa yra artima ịkrovimo įtampai, apkrovos tiristorius išsijungia. Tada valdymo grandine ijungiami Markso generatoriaus tiristoriai. Kai išejimo srovès vertè nukrenta žemiau darbinès srovès vertès, 20 tiristorių išsijungia, nes Markso generatorius yra izoliuotas nuo nuolatinès srovès tiekimo kai išjungtas apkrovos tiristorius.

Jeigu nėra reikalavimo generuoti trumpus impulsus, magnetinio lauko generatoriaus grandinès labai supaprasteja ir gali pakakti netgi vieno modulinio rakto (Grainys et al., 2015). Tokio generatoriaus principinè schema pavaizduota 1.10 paveiksle.

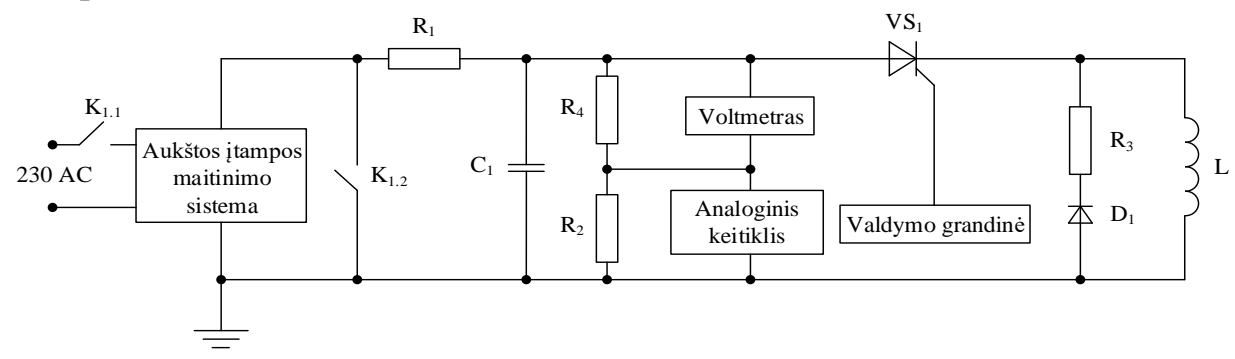

1.10 pav. $43 \mathrm{~kJ}$ magnetinio lauko generatoriaus principinè schema

(Grainys et al., 2015)

Fig. 1.10. Principle circuit of a $43 \mathrm{~kJ}$ magnetic field generator

(Grainys et al., 2015) 
Šiame formuotų impulsų generatoriuje kA dydžio srovè yra komutuojama per impulsini induktorių. Sistemoje panaudotas $\mathrm{VS}_{1}$ tiristorinis raktas $(4,2 \mathrm{kV}$ ir didžiausia srovė $53 \mathrm{kA}$ ). Vietoj dešimčiu lygiagrečiai sujungtu tranzistoriu parinktas vienas didelès galios tiristorinis raktas, tačiau jis yra apribotas pagal $\mathrm{d} I / \mathrm{d} t$. Dèl šios priežasties minimalus impulso frontas siekia šimtus mikrosekundžių, tačiau pats iškrovimo principas tinka magnetoporacijos sistemoms. Ši sistema sudaryta iš aukštos ịtampos maitinimo sistemos, kondensatorių bloko, matavimo grandinès, didelès galios rakto su valdymo grandine, kirtiklio grandinès ir apkrovos ritès. Visa sistema valdoma mikrovaldikliu. Aukštos įtampos įkrovimo grandinè valdoma $\mathrm{K}_{1.1}$ rele. Avarinio iškrovimo metu naudojama $\mathrm{K}_{1.2}$ relè, kuri iškrauna visą sukauptą energiją $C_{1}$ kondensatoriuje. $R_{1}$ yra srovę apribojanti varža. Matavimo grandinę sudaro voltmetras ir analoginis keitiklis, o $\mathrm{R}_{4}$ ir $\mathrm{R}_{2}$ yra įtampos dalikliai. Tiristorius $\mathrm{VS}_{1}$ valdomas optiškai atskirtu valdikliu. Kirtiklio grandinè sudaryta iš $\mathrm{R}_{3}$ ir $\mathrm{D}_{1}$, kurios paskirtis sumažinti atgalinę ịtampą ir kondensatorių perkrovą (Gregory et al., 1998). Šią sistemą reikia optimizuoti parenkant arba didelio $\mathrm{d} I / \mathrm{d} t$ raktus (pavyzdžiui, impulsiniai GTO tiristoriai (angl. gate turnoff thyristor) arba kaip buvo minèta aukščiau, panaudojus IGBT (angl. insulatedgate bipolar transistor) ar MOSFET (angl. metal-oxide-semiconductor fieldeffect transistor) raktu masyvus. Būtent tokio tipo grandinè buvo pasiūlyta Novickij et al. 2014 (1.11 pav.).

Impulsinį magnetinio lauko generatorių sudaro keturi pagrindiniai moduliai: 1) kondensatoriaus ịkrovimo modulis; 2) impulsą formuojantis modulis; 3 ) induktyvinè apkrova; ir 4) valdymo blokas. Ikrovimo moduli sudaro impulsinių kondensatorių blokas $(4 \times 40 \mu \mathrm{F}, 4,5 \mathrm{kV}$ lygiagrečiai sujungti kondensatoriai, $\mathrm{C}_{\mathrm{B}}=160 \mu \mathrm{F}$ ) ir aukštos įtampos reguliuojamas $4 \mathrm{kV}$ ir 7,5 mA maitinimo šaltinis, pagrịstas „Cockroft - Walton“ daugikliu. Impulsą formuojanti dalis yra sudaryta iš keturių didelès galios $\mathrm{VT}_{\mathrm{IGBT}}$ tranzistorių, kirtiklio diodo ir pereinamuju procesų kompensavimo grandinès. Keturi $\mathrm{VT}_{\mathrm{IGBT}}$ (Semikron, $\mathrm{U}_{\mathrm{CE}}=1700 \mathrm{~V}$, $\left.\mathrm{IC}_{\text {peak }}=1200 \mathrm{~A}\right)$ raktai yra sujungti nuosekliai, kad būtų galima valdyti aukštą itampą $\left(\mathrm{U}_{\max }=6800 \mathrm{~V}\right)$. Generatoriaus kondensatoriai ịkraunami iki $4 \mathrm{kV}$. Apsauginę grandinę sudaro keturi greito veikimo diodai $\left(, \mathrm{I}_{\text {peak }}\right.$ “ $=3600 \mathrm{~A}$, $\left.\mathrm{d} I / \mathrm{d} t=6400 \mathrm{~A} / \mu \mathrm{s},{ }_{\text {,Semikron" }}\right)$ ir suderintos $10 \Omega\left(\mathrm{R}_{1}-\mathrm{R}_{4}\right)$ ir $0,15 \mu \mathrm{F}\left(\mathrm{C}_{1}-\mathrm{C}_{4}\right)$ $\mathrm{RC}$ grandinès, apsaugančios raktus nuo didelių $\mathrm{d} I / \mathrm{d} t$ srovių ir viršitampių impulsų iškrovimo metu. $10 \mathrm{M} \Omega$ daliklio varžos $\left(\mathrm{R}_{\mathrm{D} 1}-\mathrm{R}_{\mathrm{D} 4}\right)$ tolygiai paskirsto nuolatinę itampą.

Kirtiklio grandinè $\left(\mathrm{D}_{\mathrm{C}}, \mathrm{R}_{5}=2,5 \Omega\right)$ naudojama atgalinès įtampos sumažinimui. Panaudoti keturi greiti (<100 ns, Fairchild) RHRG75120 diodai, kurie sujungti nuosekliai. Generatoriaus apkrovą sudaro balastinė varža $\left(\mathrm{R}_{\text {balastas }}=4 \Omega\right)$, apkrovos ritė su $R_{6}=20 \mathrm{M} \Omega$ lygiagrečiai sujungta varža ir matavimo šunto varža 
$\mathrm{R}_{\mathrm{S}}$ yra $0,025 \Omega$. Balastinė varža naudojama maksimaliai generuojamai srovei apriboti. Be to, norint sugeneruoti stačiakampius srovès impulsus apkrovoje turi dominuoti varžinè apkrova.

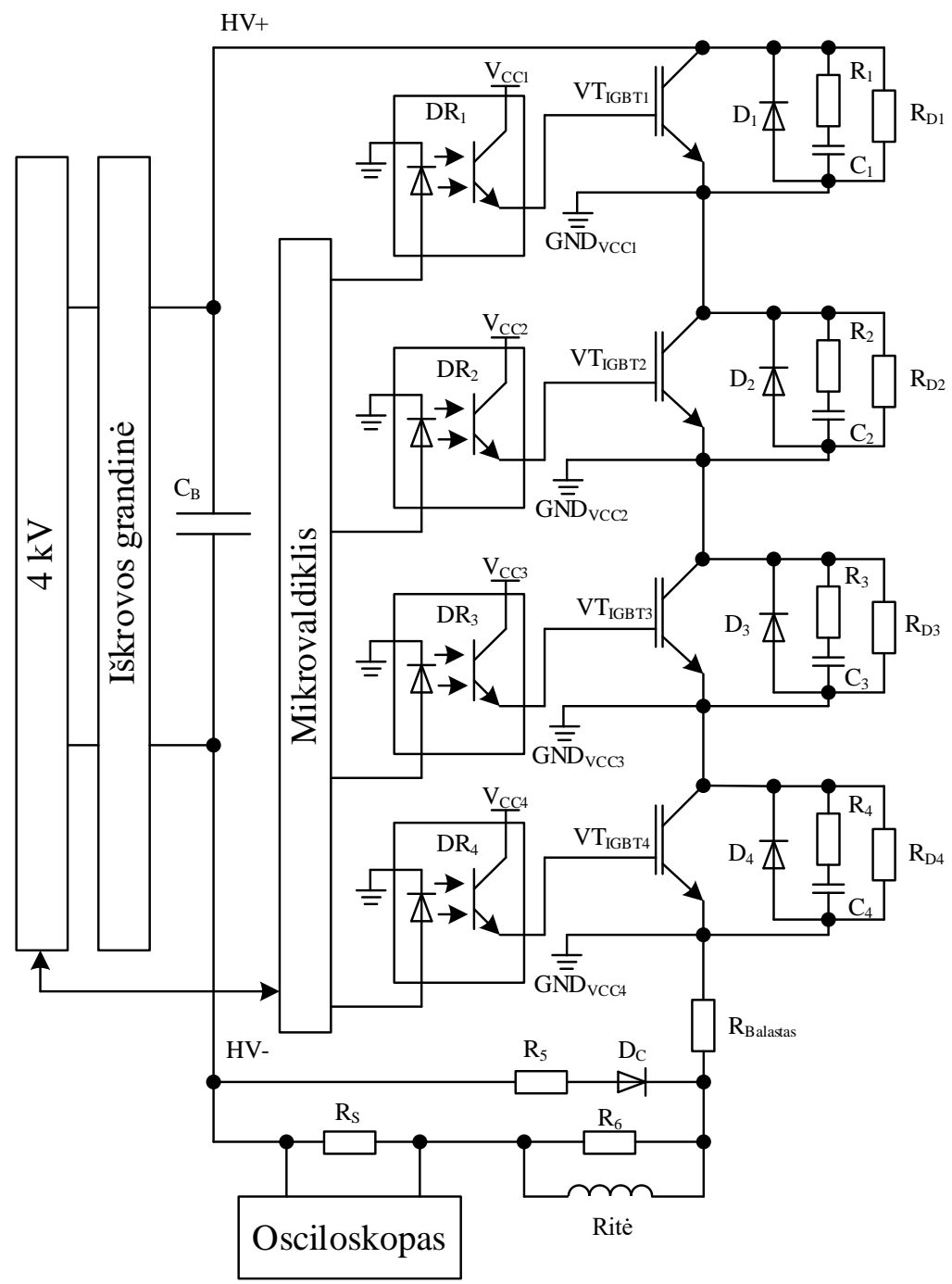

1.11 pav. Magnetinių impulsų generatoriaus skirtas magnetoporacijos tyrimams. Optinių valdikliu schema supaprastinta (V. Novickij, Grainys, Novickij, et al., 2014)

Fig. 1.11. Magnetic field generator circuit for magnetoporation experiments. Optical drivers circuit is simplified (V. Novickij, Grainys, Novickij, et al., 2014) 
Varža $\mathrm{R}_{6}$ yra naudojama tam, kad būtų išvengta aukštos įtampos kritimo ant ritès nutrukus apvijai ar atjungus induktorių. Tiksli $0,025 \Omega$ šunto varža naudojama impulsų formai išmatuoti ir ịvertinti maksimalią ritèje tekančią srovę.

Iškrovimo grandinè naudojama staigiam energijos iškrovimui iš kondensatorių, kas užtikrina papildomą apsaugą (1.12 pav.). Ją sudaro trys tiristoriai $\left(\mathrm{VS}_{1}-\mathrm{VS}_{3}\right)$, sujungti nuosekliai $\left(\mathrm{IC}=8 \mathrm{~A}\right.$ ir $\mathrm{U}_{\mathrm{CE}}=2000 \mathrm{~V}$ ) ir iškrovos varža $\mathrm{R}_{\text {iškrovimo }}=1 \mathrm{k} \Omega$. Tiristoriai yra valdomi galvaniškai atskirtu impulsiniu transformatoriumi.

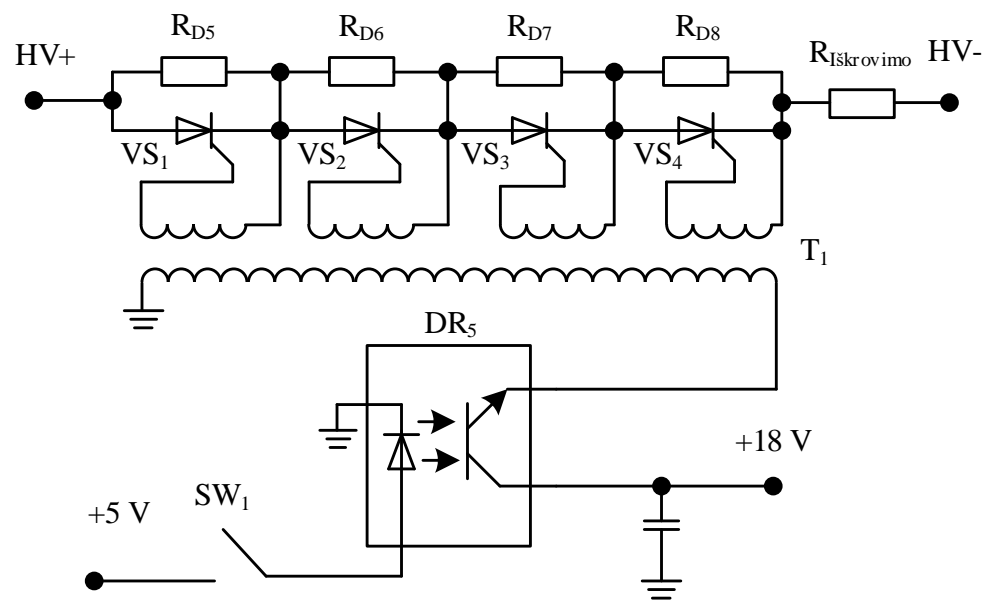

1.12 pav. Avarinio iškrovimo grandinè (V. Novickij, Grainys, Novickij, et al., 2014)

Fig. 1.12. Emergency discharge circuit (V. Novickij, Grainys, Novickij, et al., 2014)

Tiristorių veikimas yra sinchronizuotas. Toks iggyvendinimas leidžia iškrauti $160 \mu \mathrm{F}$ kondensatorius $\mathrm{C}_{\mathrm{B}}$ iki $50 \mathrm{~V}$ per $700 \mathrm{~ms}$; priešingu atveju sistema lètai

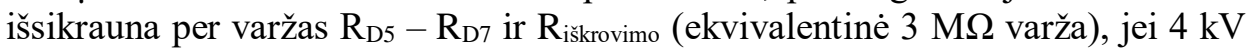
aukštos ịtampos šaltinis yra išjungtas. Be to, varžos $R_{D 5}-R_{D 7}$ naudojamos kaip dalikliai tolygiai paskirstyti nuolatinę ịtampą tarp tiristorių. Pagrindinis šios magnetoporacijos sistemos trūkumas yra mažas induktoriaus tūris ir apribota maksimali impulsinè srovè.

Dar vienas generatorius skirtas magnetoporacijai iššaukti buvo pasiūlytas Novickij et al., 2013. Impulsinị generatorių sudaro didelès galios greitai veikiantys tiristoriaus raktai, kondensatoriai, aukštos įtampos šaltinis, apkrovos ritė ir valdymo grandinè (1.13 pav.).

Trys didelès galios tiristoriai yra sujungti nuosekliai, kad būtų galima padidinti maksimalią įtampą, kuri yra $1,8 \mathrm{kV}$. Kondensatoriaus $\mathrm{C}_{2}$ verte siekia $0,3 \mu \mathrm{F}$. Magnetinio lauko generatoriaus valdymas igyvendintas naudojant mikrovaldikli. Mikrovaldiklis reguliuoja impulsų darbo ciklą ir valdo MOSFET tranzistorių $\mathrm{VT}_{1}$, 
kuris reguliuoja išèjimo įtampą. Taip pat suprojektuota kirtiklio grandinè apsaugai nuo viršitampių susidarymo. Taip pat tiristorių apsaugai naudojama RC apsauginè grandinè. Didžiausias impulsų pasikartojimo dažnis yra $40 \mathrm{~Hz}$ ir gali kisti intervale nuo $1-40 \mathrm{~Hz}$, kai didžiausia srovė yra 0-550 A diapazone. Impulsai valdomi mikrovaldiklio per valdymo grandinę. Impulsų dažnis yra apribotas dèl šiluminio poveikio susidarančio ritèje, kuri naudojama kaip apkrova.

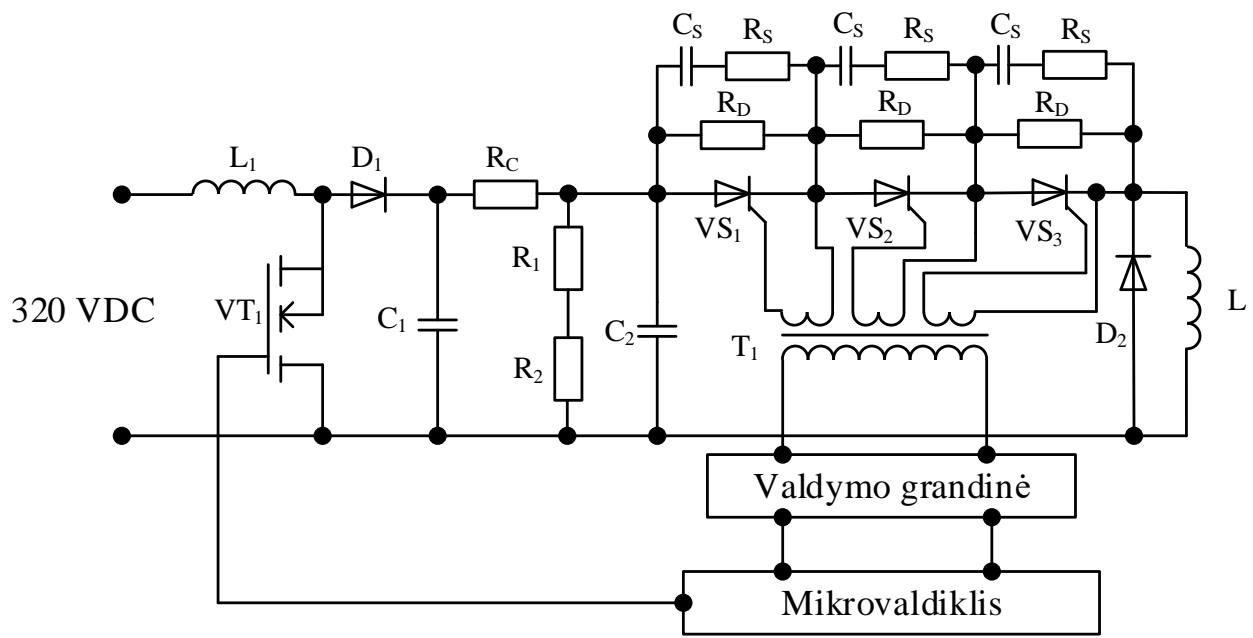

1.13 pav. Tiristorinis magnetinio lauko impulsų generatorius (V. Novickij et al., 2013)

Fig. 1.13. Thyristor-based magnetic field pulse generator (V. Novickij et al., 2013)

Analogiškai anksčiau apžvelgtai grandinei, pagrindinis šios magnetoporacijos sistemos trūkumas yra ribota komutuojama srovè ir induktoriaus tūris. Galiausiai, dèl riboto efektyvaus induktoriaus tūrio ( $\mu 1$ eilès) ir pasikartojančių impulsų, Džaulio šilumos įtaka yra neišvengiama.

\subsection{Pirmojo skyriaus išvados ir disertacijos uždavinių formulavimas}

1. Stiprių magnetinių laukų taikymas biologinėms ląstelèms gali sukelti valdomą ląstelių plazminès membranos pralaidumą, tačiau reikia didelès galios sistemų, kurių generuojamų magnetinių lauko impulsų amplitudè viršija kelias Teslas. 
2. Kuriant magnetoporacijai skirtus magnetinio lauko generatorius reikia pasiekti kompromisą tarp raktų greitaveikos, pereinamujų procesų grandinių ir valdymo sudètingumo bei maksimalių impulsų parametrų, užtikrinant kuo didesnị $\mathrm{d} B / \mathrm{d} t$.

3. Naujausios magnetoporacijos sistemos naudoja IGBT, MOSFET ir tiristorinių raktų masyvus didelès galios impulsų formavimui induktyviojoje apkrovoje, tačiau reikia kurti pereinamujų procesų grandines, norint apsaugoti raktus nuo viršitampių ir viršsrovių.

Disertacijoje suformuluoti uždaviniai:

1. Ištirti didelès galios impulsų technologijas ir pasiūlyti aukšto magnetinio lauko pokyčio per laiko vienetą magnetinių impulsų formavimo grandines, skirtas biologinių ląstelių membranų pralaidumo valdymui be tiesioginio kontakto su bandiniu.

2. İvertinti impulsiniu induktorių struktūrą, generuojamo indukuoto elektrinio lauko pasiskirstymus nuo srovès impulso formos, įšilimo efektus ir užtikrinti temperatūros stabilizavimą poveikio metu.

3. Ivertinti taikomuosius eksperimentinius sukurtu generatorių tyrimus, ịrodant efektyvumą ir pritaikomumą ląstelių membranų pralaidumo valdymui. 


\section{Impulsinių didelès galios generatoriu kūrimas ir tyrimas}

Skyriuje nagrinėjamos trijų skirtingų grandinių topologijų generatorių struktūros, apžvelgiami prototipai ir pagrindiniai sukurtų impulsinių didelès galios generatorių parametrai. Skyriaus medžiagos pagrindu paskelbtos keturios publikacijos (V. Novickij et al., 2020; V. Novickij, Grainys, et al., 2017; V. Novickij, Lastauskiene, et al., 2017; Staigvila et al., 2019).

\subsection{Markso topologijos magnetinio lauko generatorius}

Magnetoporacijos darbuose trūksta informacijos apie impulsinio magnetinio lauko amplitudę ar impulsų formą, nors tai turi ịtakos sukeltos ląstelių pralaidumo valdymo efektyvumui. Todèl, naudojant tipinę Markso generatoriaus topologiją ir dielektrinio pramušimo raktus buvo sukurtas aukšto $\mathrm{d} B$ /d $t$ generatorius. Šis generatorius sukurtas siekiant ịvertinti tikslinius magnetinio lauko parametrus.

Šiame darbe Markso generatorius buvo sudarytas iš 6 pakopų (bendra ịtampa $23 \mathrm{kV}$, pakopos ittampa 3,85 kV). Kiekvienoje pakopoje naudojama $0,15 \mu \mathrm{F}$ kondensatoriai (Cornell Dubilier, SC, JAV). Generatoriaus apkrovai naudojamas in- 
duktorius (ritè) (2 sluoksnių, 6 apvijų, kurių bendras induktyvumas $1,1 \mu \mathrm{H}$ ). Induktorius buvo suprojektuotas taip, kad tilptų 0,2 ml PGR (angl. polymerase chain reaction) sterilus mègintuvèlis (Quali, SC, JAV) biologiniams mėginiams. Vieno impulso energija yra intervale nuo 6 iki $7 \mathrm{~J}$. Pagrindinè generatoriaus schema ir gaunamas magnetinio lauko impulsas parodyti 2.1 paveiksle.

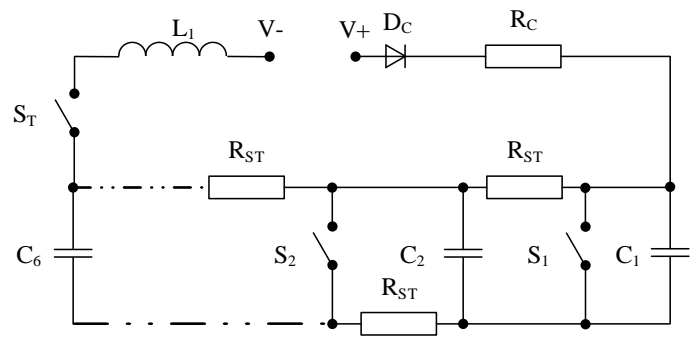

2.1 pav. Markso generatorius su induktyvine apkrova

(V. Novickij, Lastauskiene, et al., 2017)

Fig. 2.1. Marx generator with inductive load (V. Novickij, Lastauskiene, et al., 2017)

Pakopos varža $R_{\text {ST }}$ yra $150 \mathrm{k} \Omega$, o ịkrovimo srovę ribojanti varža $R_{\mathrm{C}}=20 \mathrm{k} \Omega$. Iškrovos metu buvo gautas charakteringas LC apkrovai impulsas. Gautas impulsas yra gęstantis sinusas, kurio didžiausia amplitude yra 3,3 T. Didžiausia komutuojama srovè buvo lygi $5 \mathrm{kA}$. Generatorius gali generuoti pasikartojančius impulsus, kurių pasikartojimo dažnis yra $0,25-0,5 \mathrm{~Hz}$.

Ivertinant, kad indukuotas elektrinis laukas turi didelę reikšmę biologiniam poveikiui, pikinè indukuoto elektrinio lauko amplitudè siekè iki $0,19 \mathrm{kV} / \mathrm{cm}$ dèl aukšto $\mathrm{d} B / \mathrm{d} t$ (priekinis frontas $450 \mathrm{~ns}$ ). Magnetinio lauko impulsas gautas, naudojant sukalibruotą kilpinị magnetinio lauko jutiklį, o elektrinio lauko - naudojant „Comsol multiphysiscs“ (2.2 pav.).

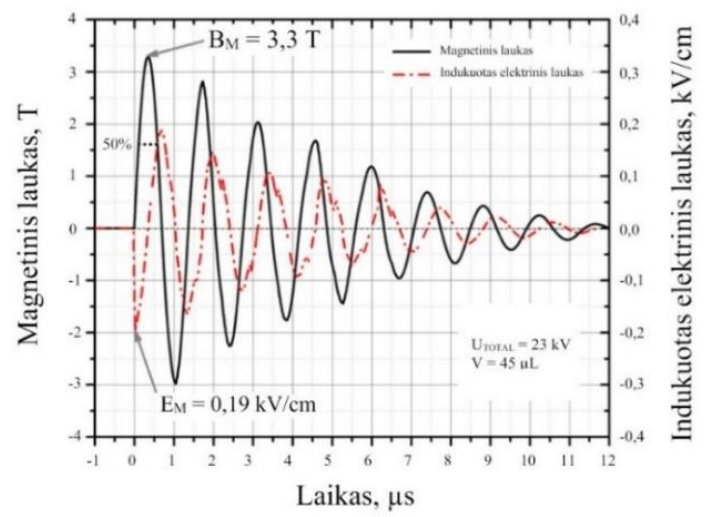

2.2 pav. Marko generatoriaus impulsas (V. Novickij, Lastauskiene, et al., 2017)

Fig. 2.2. Pulse of the Marx generator (V. Novickij, Lastauskiene, et al., 2017) 
Indukuotas elektrinis laukas dešimtis kartų viršija tipines elektrinio lauko amplitudes, kurios yra naudojamos magnetoporacijos darbuose. Bendra impulso trukmè yra apie $12 \mu \mathrm{s}$, tačiau siekiant ịvertinti poveikị ląstelèms taip pat turi būti ivertintas magnetinio ir elektrinio lauko homogeniškumas. Pasitelkta COMSOL Multiphysics (COMSOL, Stokholmas, Švedija) programine ịranga kurti imitacinius modelius. Induktoriaus modelis, magnetinio ir indukuoto elektrinio lauko erdviniai pasiskirstymai parodyti 2.3 paveiksle.

Kaip matyti 2.3 paveiksle, daugiasluoksnis solenoido tipo induktorius leidžia generuoti homogenišką ( $>90 \%$ ) magnetinị lauką ritès vidiniame tūryje, tačiau indukuotas elektrinis laukas yra nehomogeniškas ir tiesiškai mažèja link induktoriaus centro. Tai reiškia, kad ląstelès yra veikiamos nevienodai.

Taip pat Džaulio šiluma yra dažna problema biologiniuose tyrimuose kadangi gali ịtakoti ląstelių atsaką i impulsini poveikį. Dẻl šių priežasčių mėginio i̊šilimas privalo būti apribotas fiziologinių temperatūrų ruože. Tikslui pasiekti induktoriuje buvo naudojama didelio skerspjūvio emaliuota variné viela $(1,5 \times 2 \mathrm{~mm})$, kuri užtikrina mažesnę aktyviają varžą ir didesnị šiluminès energijos išsisklaidymą, kas sumažina temperatūros pokytị iki $2 \pm 0,5^{\circ} \mathrm{C}$ po 50 impulsų (3,3 T, 0,25 Hz) sekos. Matavimams buvo naudojamas „Pt1000“ jutiklis (Innovative Sensor Technology, Wattwil, Šveicarija).

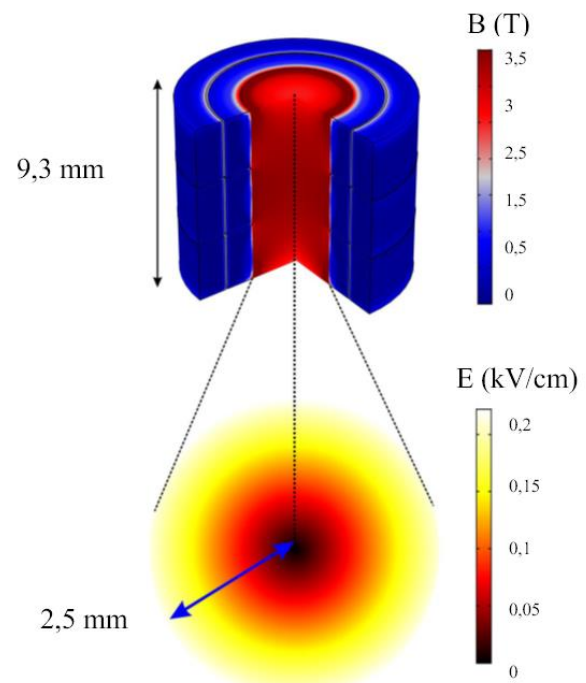

2.3 pav. Impulsinio magnetinio (viršuje) ir indukuoto elektrinio lauko (apačioje) erdvinis pasiskirstymas induktoriuje (V. Novickij, Lastauskiene, et al., 2017)

Fig. 2.3. Spatial distribution of magnetic (top) and electric (bottom) fields in the inductor (V. Novickij, Lastauskiene, et al., 2017) 
Nustačius impulsinio poveikio parametrus, buvo atlikti taikomieji Markso topologija grịsto generatoriaus tyrimai su mielių ląstelèmis. Eksperimentai buvo atlikti naudojant tradicinę elektroporaciją ir magnetoporaciją atskirai bei kartu, siekiant nustatyti galimą sinergistini poveiki. Elektroporacijai buvo naudojamas stačiakampių impulsų generatorius (V. Novickij, Grainys, Butkus, et al., 2016) ir $1 \mathrm{~mm}$ tarpo kiuvete (VWR International, Radnor, JAV). Tyrimui buvo pasirinktos Candida albicans (ATCC14053) mielès.

Poveikis buvo tiriamas, vertinant mieliu gyvybingumą ir permeabilizaciją po magnetoporacijos ir elektroporacijos. Permeabilizacijos efektyvumas buvo vertinamas fluorescenciniais dažais PI - propidžio jodidas (angl. propidium iodide) naudojant tėkmès citometriją (vidutinès fluorescencijos lygis, fluorescuojančių ląstelių skaičius). Gyvybingumas buvo vertinamas sẻjimais ant agarizuotos terpès. Koloniju formavimo vienetu po poveikio skaičius $\mathrm{CFU}_{\mathrm{T}}$ (angl. colony-forming unit) buvo lyginamas su kontrole $\mathrm{CFU}_{\mathrm{C}}$ - bandiniais, kurie nebuvo veikiami impulsiniais laukais.

Elektroporacijai buvo naudojami pavieniai $100 \mu$ s stačiakampiai impulsai, kurių amplitudė siekè $8,10,13$ ir $17 \mathrm{kV} / \mathrm{cm}$. Magnetoporacijai buvo naudojamos 3,3 T impulsų sekos po 10, 25 ir 50 impulsų.

Permeabilizacija buvo detektuojama kai stebimas fluorescencijos spektro poslinkis kuris yra pavaizduotas 2.4 paveiksle.

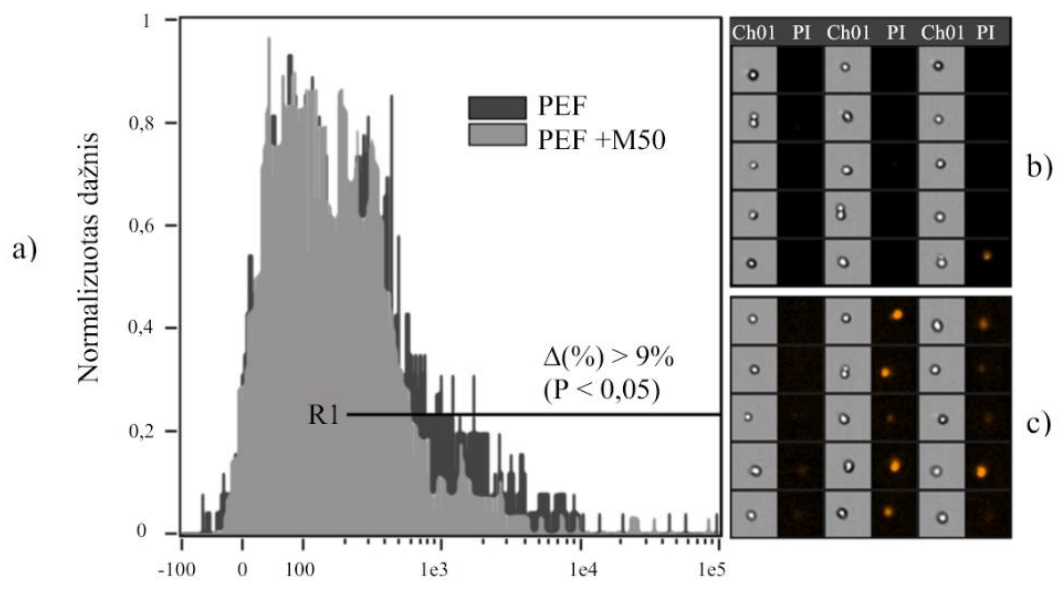

PI fluorescencinis intensyvumas (a.u.)

2.4 pav. Ląstelių fluorescencijos pavyzdžiai: a) fluorescencijos spektro poslinkis po elektroporacijos ir magnetoporacijos; b) kontrole; c) bandinys po poveikio

(V. Novickij, Lastauskiene, et al., 2017)

Fig. 2.5. Examples of cell fluorescence are: a) shift of the fluorescence spectrum after electroporation and magnetoporation; b) control; c) post-exposure sample

(V. Novickij, Lastauskiene, et al., 2017) 
Kiekybinis rezultatu ịvertinimas pateikiamas 2.5 paveiksle. Matoma, kad mielès yra atsparios nurodytų parametrų magnetoporacijai ir skirtumai tarp kontrolès ir bandinių po poveikio impulsiniu magnetiniu lauku yra statistiškai nereiškmingi. Tačiau, veikiant mieles elektriniu lauku matomas ženklus permeabilizuotų ląstelių skaičiaus padidèjimas, didinant elektrinio lauko amplitudę. Kombinuojant magnetoporaciją ir elektroporaciją matomas statistiškai patikimas $(\mathrm{P}<0,05)$ skirtumas, tačiau skirtingai negu tikètasi, matomas permeabilizuotų ląstelių skaičiaus sumažejjimas. Eksperimentinių bandymų metu konstatuota, kad nurodytų parametrų generatorius gali būti naudojamas sukelti detektuojamus pokyčius mielių ląstelèse. Tačiau, mielių ląstelès dẻl išorinès sienelès yra daug atsparesnès fiziniam poveikiui negu gyvūninės ląstelès, todèl sukurtas generatorius buvo taip pat pritaikytas su Sp2/0 vėžinėmis ląstelėmis (V. Novickij, Girkontaite, et al., 2017). Nustatyta, kad nurodytų parametrų magnetinio lauko impulsai yra tinkami sukelti grịžtamąją magnetoporaciją gyvūninèse ląstelèse.
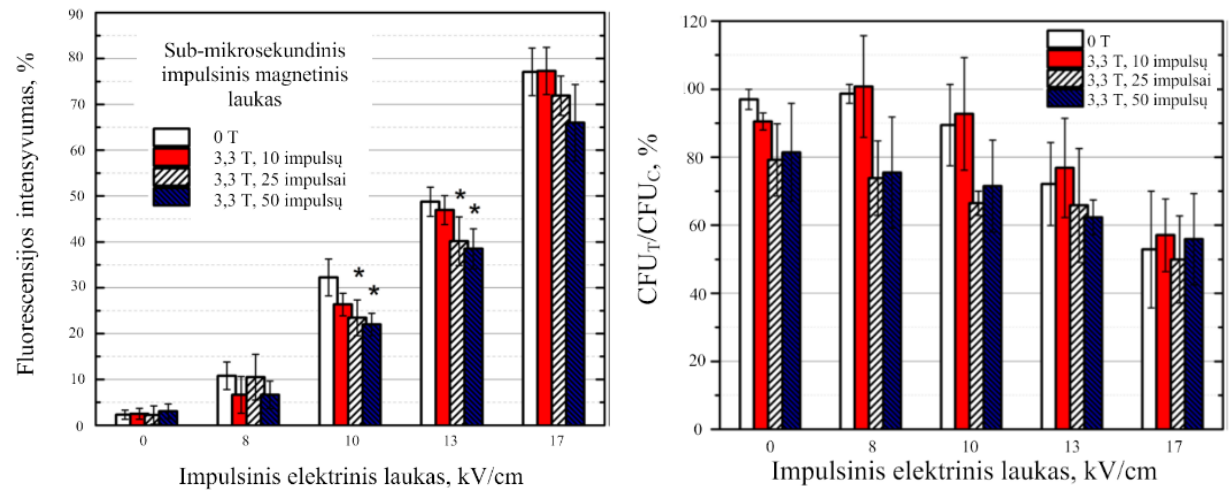

2.5 pav. C. Albicans permeabilizacija (kairèje) ir gyvybingumas (dešinèje) po impulsinio poveikio, kur žvaigždutè $(*)$ rodo statistiškai reikšmingą $(\mathrm{P}<0,05)$ skirtumą lyginant su elektroporacija (V. Novickij, Lastauskiene, et al., 2017)

Fig. 2.5. Permeabilization (left) and vability (right) of C. albicans after pulsed treatment, where asterisk $(*)$ corresponds to statistical difference $(\mathrm{P}<0.05)$ versus electroporation only treatment (V. Novickij, Lastauskiene, et al., 2017)

Matoma, kad nors vidutinis gyvybingumo lygis krito kombinuojant elektroporaciją ir magnetoporaciją, tačiau daugelyje atvejų skirtumai nèra statistiškai patikimi.

Ivertinant visų biologinių eksperimentų rezultatus buvo patvirtinta, kad $3 \mathrm{~T}$ impulsinis magnetinis laukas yra pakankamas sukelti detektuojamus pokyčius biologiniuose objektuose, todèl nurodyta amplitudè buvo pasirinkta kaip minimali tolimesniems generatorių prototipams. 


\subsection{Magnetinio lauko generatorius su ignitrono raktu}

Eksperimentiškai patvirtinta, kad $3 \mathrm{~T}$ submikrosekundinio fronto impulsu pakanka sukelti magnetoporaciją, tačiau tam reikalingos 4-5 kA srovès. Atsižvelgiant į aukštą $\mathrm{d} I / \mathrm{d} t$ ir $\mathrm{kV}$ diapazono ịtampą, buvo padaryta išvada, kad tokiems impulsams formuoti geriausiai tinka ignitronas.

Sukurtas impulsinis generatorius grịstas Ignitrono (NL-1038, National Electronics, Farmingdale, NY, USA) tipo raktu. Ignitronas tai nepuslaidininkinis elektronikos įtaisais, kurio viduje yra gyvsidabrio. Naudojant ignitroną kaip pagrindinį komutavimo ịrengini, prietaisas sudètingèja, nes reikia sukurti 2 atskirus generatorius. Vienas generatorius skirtas energijos kondensatoriuose iškrovimui per induktyvią apkrovą, kitas - formuoti valdymo impulsui.

Generatoriaus supaprastinta struktūrinè schema pavaizduota 2.6 paveiksle. Valdymo impulso formavimas grịstas RC grandinès iškrovimu naudojant 2 tiristorinius raktus $\mathrm{VS}_{1-2}$ (IXYS MCO500-12IO1, USA). Energija, reikalinga sukurti impulsui, kaupiama $\mathrm{C}_{3} 0,33 \mu \mathrm{F}$ kondensatoriuje, tam naudojame nuolatinès aukštos įtampos $2 \mathrm{kV}$ šaltinị.

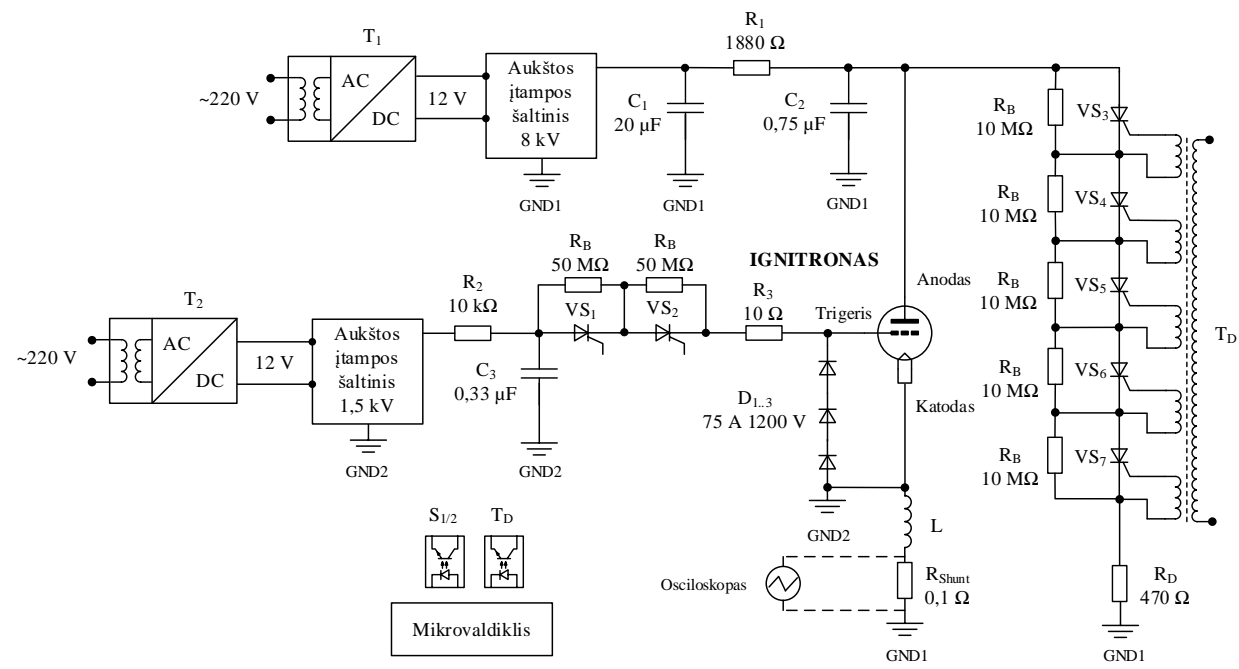

2.6 pav. Principinè impulsinio magnetinio lauko generatoriaus su ignitrono tipo raktu schema (Staigvila et al., 2019)

Fig. 2.6. Principle circuit of a magnetic field generator with ignitron switch

(Staigvila et al., 2019) 
Valdymo generatoriuje naudojami 2 nuosekliai sujungti tiristoriniai raktai $\mathrm{VS}_{1-2}$, lygiagrečiai prijungtos dvi $\mathrm{R}_{\mathrm{B}} 50 \mathrm{M} \Omega$ („OHMITE“) varžos, tam, kad vienodai paskirstytų nuolatinè itampa. Valdymo grandinès impulso srovei apriboti tiristoriai nuosekliai sujungti su $\mathrm{R}_{3} 10 \Omega$ varža. Generatorius suprojektuotas taip, kad nuolatinè valdymo įtampa $1500 \mathrm{~V}$ yra palaikoma kondensatoriuje $\mathrm{C}_{3}$. Siekiant sumažinti induktyvumo ịtaką valdymo impulsui panaudoti trys diodai atgalinės įtampos kirtiklio grandinei sudaryti (angl. crowbar) $\left(\mathrm{D}_{1-3}\right) 75$ A $1200 \mathrm{~V}$. Susidaręs kontūras tarp apkrovos ir diodų neleidžia atgalinei ịtampai paveikti ignitrono atsidarymo.

Varža $R_{2}(10 \mathrm{k} \Omega)$ apsaugo valdymo grandinès aukštos įtampos šaltinị (Spellman $2 \mathrm{kV}$ ), kad energijos iškrovimo metu dèl kondensatoriaus $\mathrm{C}_{3}$ nesusidarytų trumpas jungimas grandinèje.

Generatoriaus valdymui naudojamas mikrovaldiklis XMEGA128A3U (Atmega, San Jose, CA, USA), kuris galvaniškai atskirtas valdikliu ADUM4223ARWZ (Analog Devices, Norwood, MA, USA).

Pagrindinė generatoriaus maitinimo grandinė sudaryta iš nuolatinės aukštos itampos maitinimo šaltinio $8 \mathrm{kV}$,Spellman“ bei kondensatorių $\mathrm{C}_{1}=20 \mu \mathrm{F}$ ir $\mathrm{C}_{\text {DIS }}=0,75 \mu \mathrm{F}$. Energija kaupiama kondensatoriuose $\mathrm{C}_{1}$, bet dèl to, kad reikalingi pasikartojantys impulsai, papildomai naudojami Cornell Dubilier kondensatoriai. Varža $R_{1} 1880 \Omega$ naudojama srovès apribojimui ir aukštos įtampos $8 \mathrm{kV}$ šaltinio apsaugai nuo trumpo jungimo iškrovimo metu.

Apsauginè iškrovos grandinè suprojektuota tam, kad sukauptą energiją kondensatoriuose $C_{1}$ ir $C_{D I S}$ būtų galima iškrauti varžoje $R_{D} 470 \Omega$. Grandinè sudaryta iš keturių tiristorių $\mathrm{VS}_{3-7}$, ir jiems lygiagrečių varžų $\mathrm{R}_{B} 10 \mathrm{M} \Omega$. Apsauginè grandinè veikia nepriklausomai nuo visos likusios generatoriaus grandinès ir yra valdoma naudojant transformatorių ir fizinị mygtuką.

Prototipo valdymo ir maitinimo grandinès yra galvaniškai atskirtos. Generatoriuje kaip apkrova naudojama rite L. Impulso formos matavimai atliekami ant nuoseklios varžos $\mathrm{R}_{\text {šutas }} 0,1 \Omega$. Generatoriaus eksperimentinis prototipas yra pavaizduotas 2.7 paveiksle.

Norint užtikrinti suprojektuotos schemos veikimą ir sumažinti pagrindinių raktų gedimo rizikas visos grandinès buvo ištirtos atskirai. Ignitroną valdo du tiristoriai ir mikrovaldiklis. Visos grandinès yra galvaniškai atskirtos naudojant izoliacinius transformatorius arba valdiklius. Atsižvelgiant ị ignitrono aprašymą, valdymui reikia 5-10 $\mu \mathrm{s}, 1,5-3 \mathrm{kV}$ impulsų, srovei viršijant 100 A. Valdymo grandinių impulsas matuojamas tarp ignitrono trigerio ir katodo, gauti rezultatai pavaizduoti 2.9 paveiksle B. 


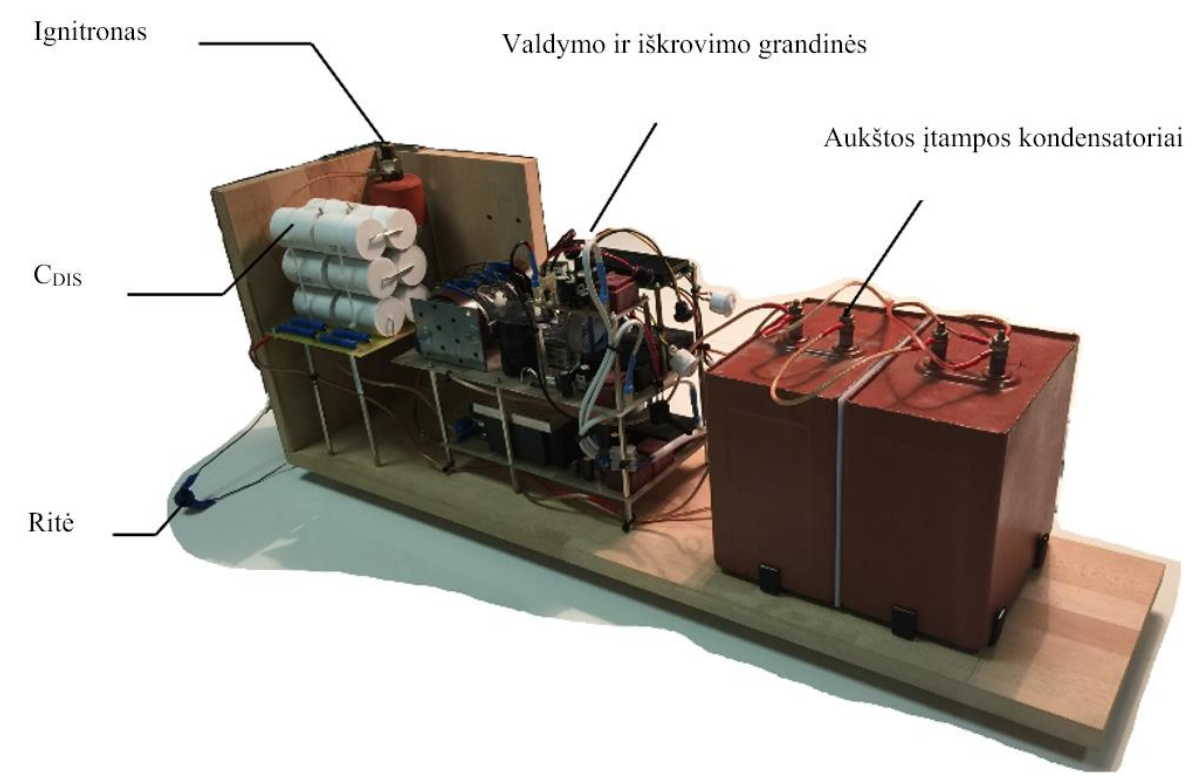

2.7 pav. Generatoriaus prototipas

(Staigvila et al., 2019)

Fig. 2.7. The generator prototype

(Staigvila et al., 2019)

Matoma, kad mikrovaldiklis generuoja $20 \mu \mathrm{s} 3,3 \mathrm{~V}$ impulsus ị optinio atrišimo valdiklius (2.6 pav.), kurie ši signalą galvaniškai atriša ir sustiprina iki $4 \mathrm{~V}$ ir maksimalios 5 A srovès, skirtos valdyti tiristorinius raktus. Paveiksle 2.9 A išmatuoti mikrovaldiklio impulsų matavimai išèjimo taškuose ir tiristorių $\mathrm{U}_{\mathrm{GT}} \operatorname{tarp}$ užtūros ir katodo. U $\mathrm{U}_{\mathrm{GT}}$ yra $66 \%$ nuo maksimalios kritinès įtampos, kurią palaiko nurodytų modelių tiristoriai, kas pilnai atitinka projektavimo užduotį. Taip pat galima pastebèti, kad valdymo impulsų amplitudès nedaug skiriasi tarp dviejų tiristorių, nors valdymo grandinès ir pakrovimo įtampos yra identiškos. Šie skirtumai gali būti ịtakojami gamyklinių parametrų tarp skirtingų raktų, tačiau skirtumai yra nedideli ir neįtakoja raktų atidarymo, kadangi $\mathrm{U}_{\mathrm{GT}}$ ir paleidimo srovè daug kartų viršija minimalią ribinę srovę šių tiristorių valdymui.

Tiristoriai iškrauna visą energiją sukauptą talpoje $C_{3}$. Itvertinant, kad ignitrono paleidimas yra griežtai apribotas $5-10 \mu$ s trukmès diapazone, buvo parinktas $\mathrm{C}_{3}=0,33 \mu \mathrm{F}$, kad bendra RC grandinès konstanta apribotų valdymo impulsų trukmę. 2.9 B paveiksle matoma, kad impulso trukmé neviršija $10 \mu \mathrm{s}$, kas atitinka darbo užduotį. 
a)
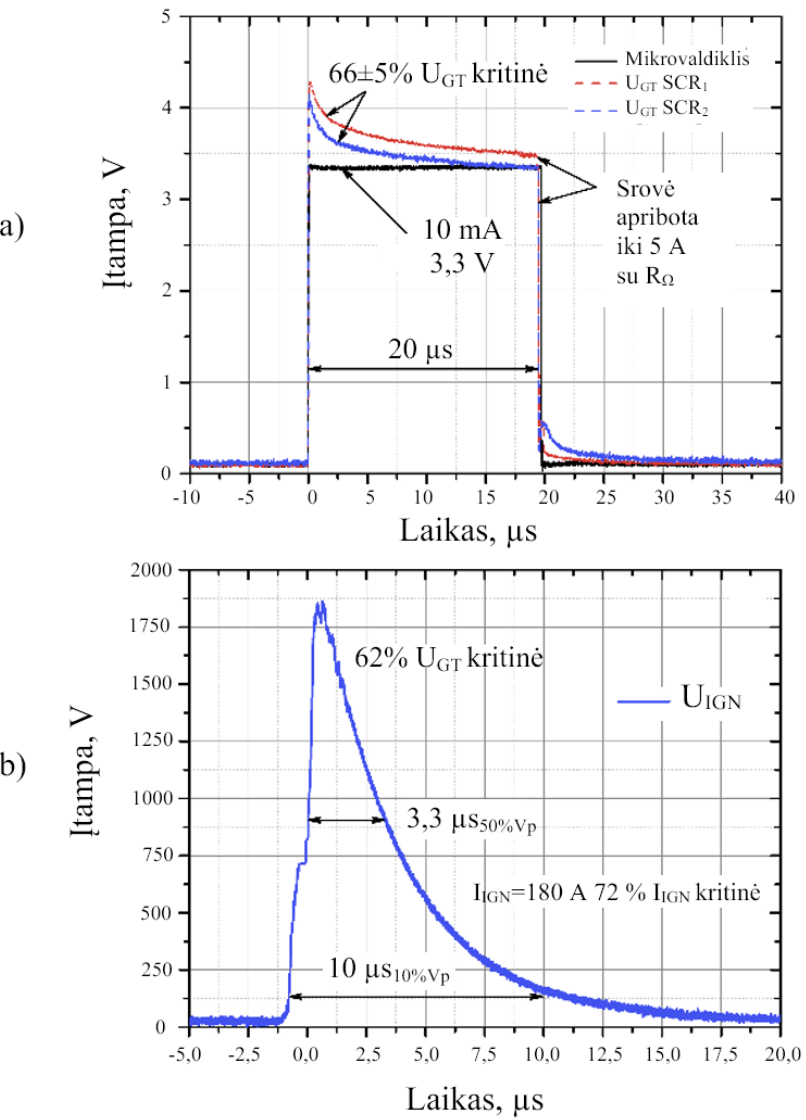

2.8 pav. Valdymo grandinių išèjimo impulsai: a) valdiklių impulsai;

b) ignitrono valdymo grandinès impulsas (Staigvila et al., 2019)

Fig. 2.8. Control circuit output pulses: a) controllers pulses;

b) ignitron control circuit pulse (Staigvila et al., 2019)

Šio modelio ignitronas yra skirtas komutuoti daugiau negu $20 \mathrm{kV}$ ịtampas ir sroves viršijančias $100 \mathrm{kA}$. Tačiau, jis naudojamas mažesnèms galioms komutuoti, todèl $\mathrm{U}_{\mathrm{IGN}}$ siekiančios $62 \%$ nuo maksimalios ribinès įtampos tikrai pakanka $8 \mathrm{kV}$, iki $10 \mathrm{kA}$ impulsams komutuoti. Kaip matoma valdymo srove yra $180 \mathrm{~A}$, kas ženkliai viršija minimalią 100 A valdymo srovę.

Generatoriaus bandymui kaip apkrova buvo naudojama ritė (dviejų sluoksnių, šešių apvijų ir $\mathrm{L}=1,4 \mu \mathrm{H}$ ). Apvijoms buvo pritaikyta didelio skerspjūvio emaliuota varinè viela $\left(1,5 \times 2 \mathrm{~mm}^{2}\right)$. Palyginimui, kaip apkrova, taip pat buvo naudojama 2,4 $\Omega$ varža. Atitinkamų impulsų formos yra pavaizduotos 2.9 paveiksle. 


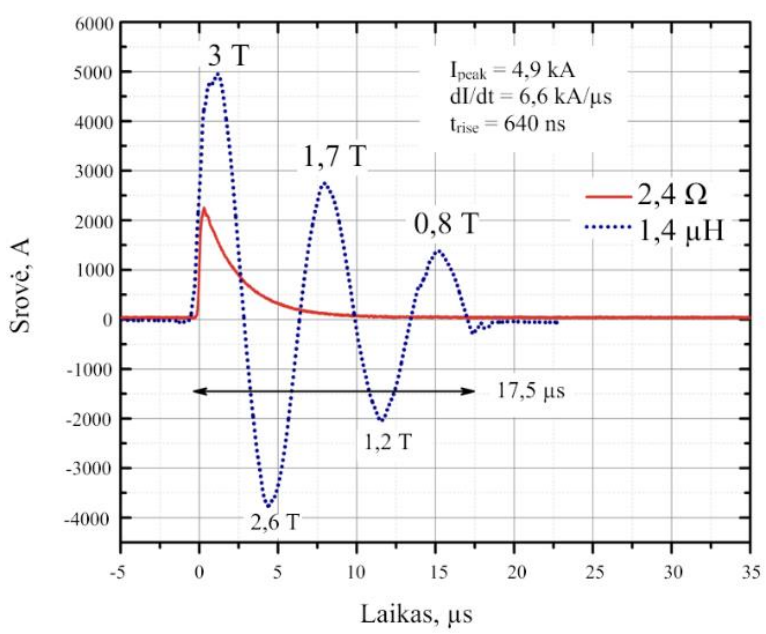

2.9 pav. Generatoriaus impulso formos naudojant induktyvią ir varžinę apkrovas (Staigvila et al., 2019)

Fig. 2.9. The output waveforms of the generator with inductive and resistive loads (Staigvila et al., 2019)

Matoma, kad generatorius gali formuoti didelès galios impulsus su sub-mikrosekundinès trukmès frontu $(640 \mathrm{~ns}$, kai $\mathrm{L}=1,4 \mu \mathrm{H})$, kuris užtikrina aukštą $\mathrm{d} B / \mathrm{d} t$ ir tokiu būdu leidžia indukuoti pakankamą elektrinį lauką magnetoporacijos tyrimams. Generuojamo srovès impulso aukščiausia vertė yra 4,9 kA, kai ịkrovimo įtampa yra $6,5 \mathrm{kV}$, o didžiausias $\mathrm{d} / / \mathrm{d} t-6,6 \mathrm{kA} / \mu \mathrm{s}$. Bandymo metu taip pat buvo sugeneruotas ir RC impulso signalas įsitikinti, kad ignitronas formuoja mikrosekundinius impulsus nepriklausomai nuo apkrovos tipo.

Galiausiai buvo ištirta avarinio iškrovimo grandinè. Kondensatoriai buvo ịkrauti ir iš karto iškrauti. Iškrovos impulso forma išmatuota ant varžos $\mathrm{R}_{\mathrm{D}}$ parodyta 2.10 paveiksle.

Kaip matyti 2.10 paveiksle, kondensatoriai visiškai išsikrauna mažiau nei per $1,5 \mathrm{~ms}$. Grandiné nepriklauso nuo mikrovaldiklio, todèl veikia net esant mikrovaldiklio gedimui tokiu būdu apsaugant vartotoją.

Galiausiai buvo sumodeliuotas generuojamo magnetinio lauko erdvinis pasiskirstymas induktoriuje, naudojant COMSOL programinę įrangą. Rezultatai yra pateikiami 2.11 paveiksle.

Matoma, kad imitaciniame modelyje nustatytos reikšmès atitinka išmatuotą $3 \mathrm{~T}$ magnetinio lauko amplitudę ir disertacijoje iškeltą tikslą sistemos parametrams. Sistema gali generuoti pavienius ir pasikartojančius $(1 \mathrm{~Hz})$ impulsus su sub-mikrosekundiniu frontu. 


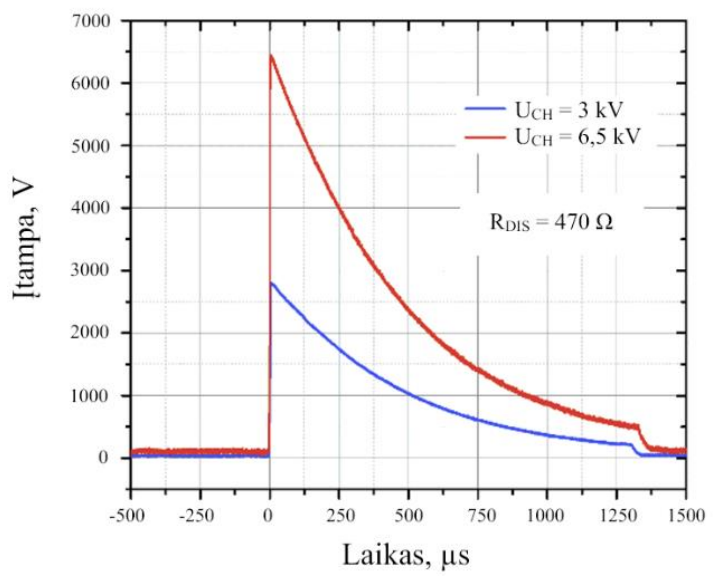

2.10 pav. Avarinio iškrovimo grandinès impulso forma

(Staigvila et al., 2019)

Fig. 2.10. The output pulse of the emergency discharge circuit

(Staigvila et al., 2019)

Didelis $\mathrm{d} B / \mathrm{d} t$ taip pat leidžia indukuoti iki $68 \mathrm{~V} / \mathrm{cm}$ elektrini lauką, kas dešimtis kartų viršija ribinius elektrinius laukus magnetoporacijos darbuose.

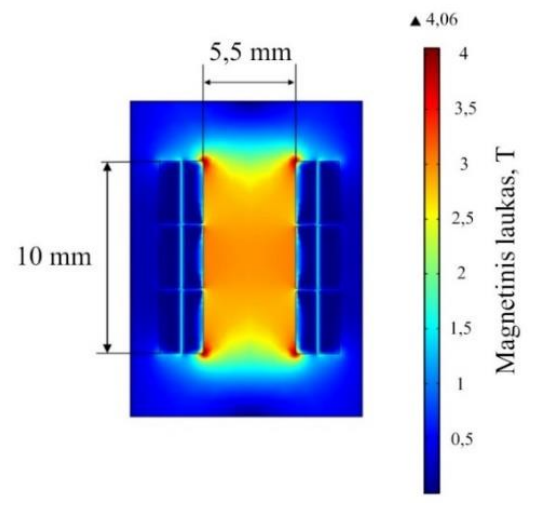

2.11 pav. Magnetinio lauko erdvinis pasiskirstymas induktoriaus viduje (Staigvila et al., 2019)

Fig. 2.11. Spatial distribution of magnetic field inside the inductor (Staigvila et al., 2019) 


\subsection{Impulsinis generatorius gristas tiristoriniais raktais}

Buvo sukurta trečioji impulsinė sistema skirta generuoti iki $10 \mathrm{~T},>10 \mathrm{~V} / \mathrm{cm}$ pasikartojančius impulsus. Impulsų formavimui buvo naudojami du MCC255-16io1 (IXYS, JAV) tiristoriniai (SCR) moduliai $\mathrm{VS}_{1}$ ir $\mathrm{VS}_{2}$. Struktūrinè generatoriaus schema pavaizduota 2.12 paveiksle.

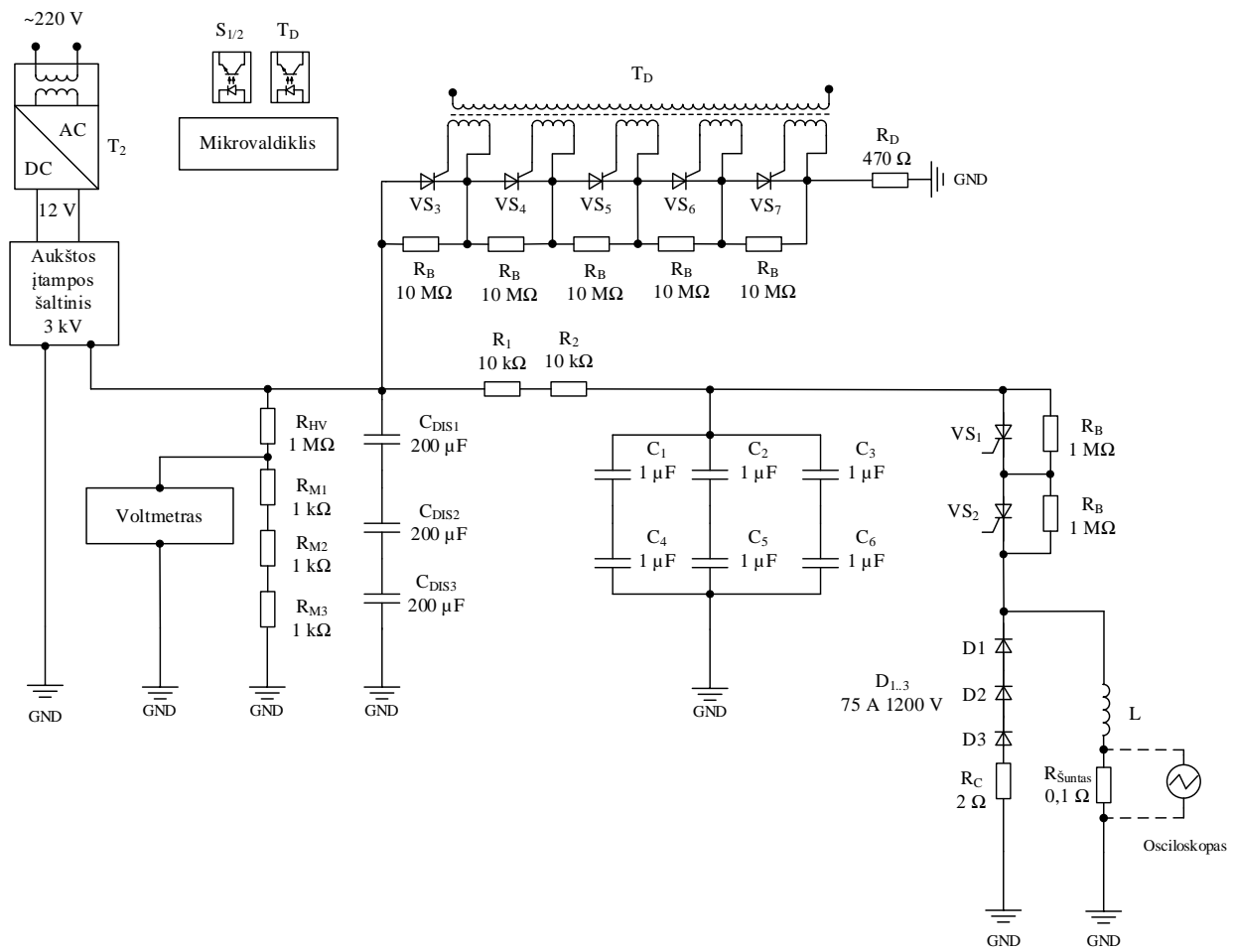

2.12 pav. Tiristorinio impulsinio magnetinio lauko generatoriaus schema

(V. Novickij et al., 2020)

Fig. 2.12. The scheme of the thyristor-based magnetic field generator

(V. Novickij et al., 2020)

Dèl $\mathrm{d} I / \mathrm{d} t$ apribojimo (šiuo atveju $500 \mathrm{~A} / \mu \mathrm{s}$ ), maksimali srovè grandinèje apribota iki 1,5 kA. Tokiu būdu apsaugomi ne tik tiristoriniai raktai bet ir sumažinama Džaulio šilumos įtaka, naudojant daugiasluoksnius induktorius.

Maitinimo grandinè sudaryta iš dviejų kondensatorių baterijų analogiškai, kaip ignitronu grịstas generatorius, užtikrinant galimybę generuoti pasikartojančius impulsus. Pirmoji kondensatorių baterija susideda iš filtro tipo kondensatorių 
(KNG1914, ISKRA, Slovėnija) $(3 \times 200 \mu \mathrm{F}$ nuosekliai $=66,67 \mu \mathrm{F})$, o antroji aukšto $\mathrm{d} / / \mathrm{d} t$ impulsinių kondensatoriu $(940 \mathrm{C} 20 \mathrm{~W} 1 \mathrm{~K}-\mathrm{F}$, Cornell Dobilier, JAV; $6 \times 1 \mu \mathrm{F}$ nuosekliai ir lygiagrečiai $=1,5 \mu \mathrm{F})$. Kondensatorių baterijų pakrovimo itampa buvo apribota iki $3 \mathrm{kV}(0-3 \mathrm{kV})$ naudojant UM4 * 4 (Spellman, JAV) įtampos keitiklị. Tarp atskirų kondensatorių baterijų naudojama $20 \mathrm{k} \Omega$ varža, kuri riboja impulsinių kondensatorių įkrovimo srovę. Šių parametrų grandinè palaiko pasikartojančių impulsų dažnị iki $5 \mathrm{~Hz}$.

Kirtiklio (angl. crowbar) grandinè $\left(\mathrm{D}_{1-3}, \mathrm{RC}\right)$ buvo naudojama kondesatorių perkrovai ir atgalinès įtampos ribojimui. Pagrindiniai generatoriaus raktai (tiristoriai) buvo sujungti nuosekliai, siekiant padidinti maksimalią komutuojamą įtampą iki 3,2 kV. Kaip apkrova, šiame generatoriuje gali būti naudojamas bet kokio tipo induktorius, kurio rekomenduojama induktyvumo verte yra $<10 \mu \mathrm{H}$, kas užtikrintų $>1 \mathrm{kA}$ srovę ir pakankamus kilimo/kritimo frontus magnetoporacijai užtikrinti. Generatoriaus prototipas pavaizduota 2.13 paveiksle.

Valdymo ir galios grandinès

Tiristorinis raktas

a)

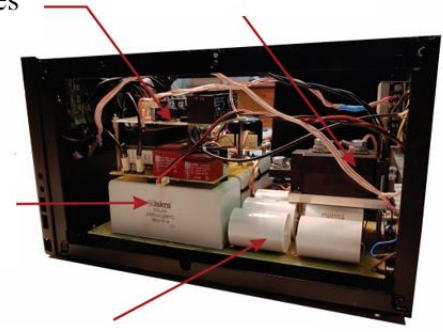

Impulso formavimui skirti aukštos $\mathrm{d} I / \mathrm{d} t$ kondensatoriai

Aukštos ịtampos

kondensatoriai

- $37,5 \mathrm{~cm} \rightarrow$

LCD ekranas

b)

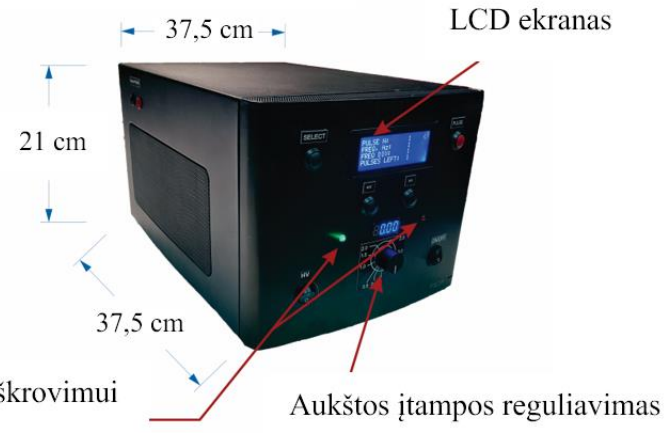

2.13 pav. Sukurto generatoriaus: a) elektronikos komponentai; b) korpusa;

(V. Novickij et al., 2020)

Fig. 2.13. Developed generator: a) The electronic components; b) the housing

(V. Novickij et al., 2020) 
Taip pat kaip ir ignitrono generatoriuje buvo įdiegta avarinio iškrovimo grandinè $\left(\mathrm{VS}_{3}-\mathrm{VS}_{7}\right)$. Ją ijungia galvaniškai atskirtas trigeris $\left(\mathrm{T}_{\mathrm{D}}\right)$, kuris valdomas mygtuku atskirai nuo pagrindinio mikrovaldiklio (XMEGA128, Atmel, JAV). Apkrovai buvo panaudoti trys skirtingi induktoriai $(11,8-14 \mu \mathrm{H})$, keičiant efektini tūrị ir apvijų skaičių. Buvo sukurtos tokios ritès: A ritè: $(6 \mathrm{~L} \times 8 \mathrm{~W}$, viela: $0,5 \mathrm{~mm}$, $\mathrm{r}=2 \mathrm{~mm})$; B ritè: $(6 \mathrm{~L} \times 8 \mathrm{~W}$, viela: $0,8 \mathrm{~mm}, \mathrm{r}=2 \mathrm{~mm})$; $\mathrm{C}$ ritè: $(6 \mathrm{~L} \times 8 \mathrm{~W}$, viela: $0,8 \mathrm{~mm}, \mathrm{r}=3 \mathrm{~mm})$, kur L ir W atitinkamai yra sluoksniai ir apvijos. Vidinių ričių minimalus skersmuo buvo pritaikytas taip, kad atitiktų standartinio 0,2 ml sterilaus PGR mėgintuvèlio skersmenị (ABgene, ThermoFisher Scientific, JAV).

Induktoriai ir magnetinio lauko impulsų formos parodytos 2.14 paveiksle.

a)

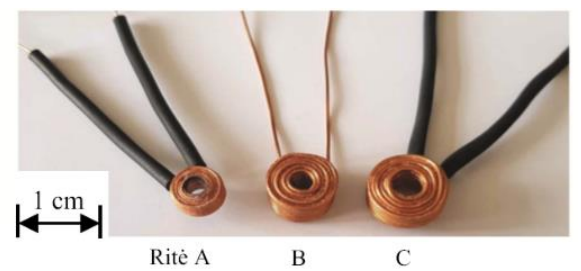

b)

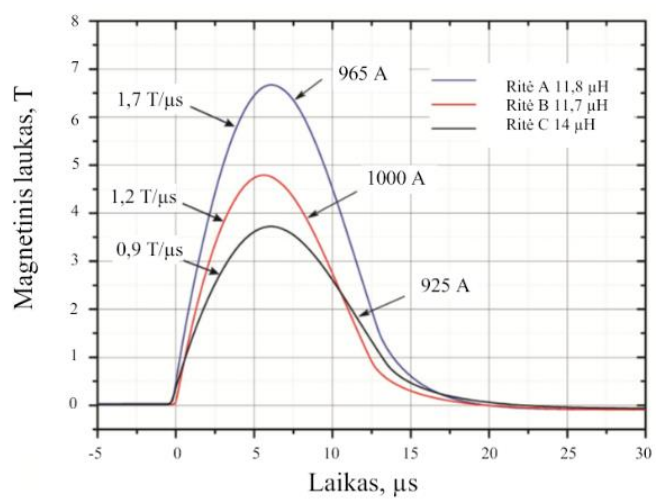

2.14 pav. Magnetinio lauko priklausomybès sąryšis: a) sukurtų induktorių; b) magnetinio lauko impulsu formos (Staigvila et al., 2019)

Fig. 2.14. Magnetic field dependence relationship: a) created inductors; b) pulse shapes of magnetic fields (Staigvila et al., 2019)

Magnetinis laukas buvo išmatuotas sukalibruotu kilpiniu jutikliu (VGTU, Vilnius, Lietuva). Srovių stiprio vertès buvo nustatytos naudojant šuntą $\mathrm{R}_{\text {šntas }}$ nuosekliai sujungtą su apkrovos rite (žr. 2.12 pav.). Kadangi gaunami ričių induktyvumai yra panašūs, srovès taip pat yra panašios $(0,92-1 \mathrm{kA})$, tačiau ričių fizikiniai matmenys skiriasi, todèl magnetinio lauko impulsų amplitudès taip pat skiriasi. 2.14 paveiksle matoma, kad didžiausią magnetinio lauko vertę $(6,7 \mathrm{~T}, 3 \mathrm{kV}$ ịkrovimo ịtampa) pasiekiama naudojant A ritę (mažiausias efektinis tūris). 
Norint įvertinti Džaulio ịšilimą buvo naudojama šviesolaidinè temperatūros jutiklių sistema (opSens, Québec, Kanada), kurią sudare „ProSens“ signalų apdorojimo blokas ir temperatūros jutiklis OTG-M170. Jutiklis buvo įdètas į PGR mėgintuvèlį, užpildytą ląstelių terpe, ir buvo sugeneruota 100 impulsų (1 Hz) su maksimalia amplitude $(6,7 \mathrm{~T})$. Papildomam aušinimui buvo naudojamas ledas. Rezultatai pateikiami 2.15 paveiksle.

a)
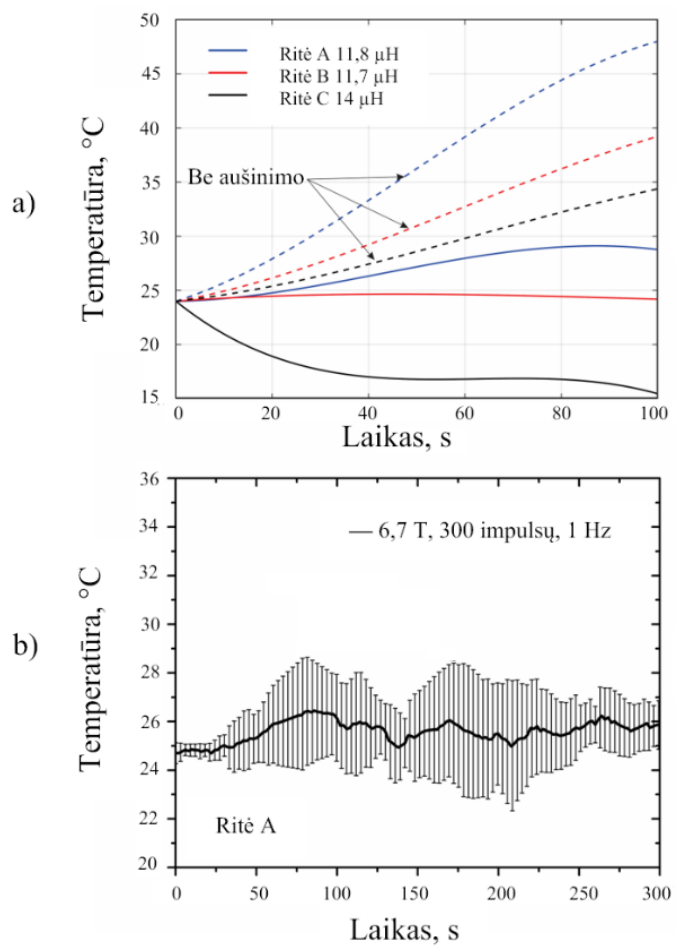

2.15 pav. Temperatūros pokyčiai ritėse: a) skirtingų struktūrų ritėse po 100 impulsų, be aušinimo; b) po 300 impulsų naudojant ritę A su aušinimu (V. Novickij et al., 2020)

Fig. 2.15. Temperature changes in coils: a) in coils of different structures at 100 pulses, without cooling; b) 300 pulses using coil A with cooling (V. Novickij et al., 2020)

Matoma, kad nenaudojant papildomo aušinimo bandinys įkaista greitai, viršijant fiziologines temperatūras, todèl nurodytų parametrų induktoriai negali būti naudojami magnetoporacijos tyrimuose be aušinimo. Panaudojus ledą visų trijų ričių įšilimas yra sẻkmingai apribotas, tačiau įvertinant, kad ritė A užtikrina didžiausią $\mathrm{d} B / \mathrm{d} t$ todèl ir buvo pasirinkta tolimesniems tyrimams.

Generuojant ilgesnes sekas (pvz. 300 impulsų) temperatūra yra taip pat sẻkmingai apribota $\pm 5^{\circ} \mathrm{C}$ ruože, kas atitinka darbo tikslą. Aušinimo efektyvumui 
turi įtakos ledo padèties pakitimas kai pradeda tirpti ledas, tačiau nukrypimas yra nežymus $\pm 3{ }^{\circ} \mathrm{C}$.

Norint įvertinti erdvinị magnetinio ir elektrinio laukų pasiskirstymą buvo sudarytas COMSOL modelis. Rezultatai pateikiami 2.16 paveiksle.

a)

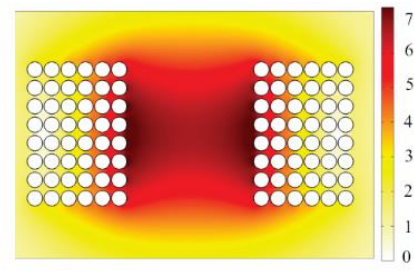

b)

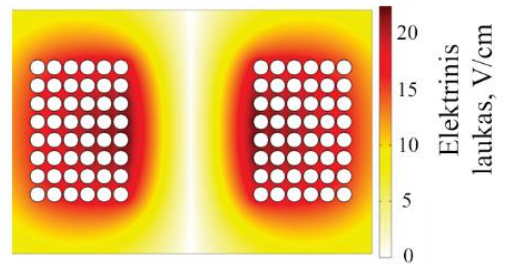

2.16 pav. Erdviniai pasiskirstymai: a) magnetinio lauko; b) elektrinio lauko (V. Novickij et al., 2020)

Fig. 2.16. Spatial distributions: a) magnetic field; b) electric field (V. Novickij et al., 2020)

Matoma, kad imitacinio modelio rezultatai atitinka išmatuotą magnetinio lauko amplitudę, kur pasiskirstymas yra sąlyginai homogeniškas ( $>90 \%)$. Didžiausia indukuoto elektrinio lauko amplitudè viršija $15 \mathrm{~V} / \mathrm{cm}$, tačiau pasiskirstymas yra nehomogeniškas, kas yra tipiška šios struktūros induktoriams.

\subsection{Generatorių skirtų magnetoporacijai palyginimas}

Magnetoporacijos sritis yra nauja ir sistemų pritaikytų magnetoporacijos tyrimams yra nedaug. Sistemos skirtos in vitro turi palaikyti dideles sroves ir aukštą $\mathrm{d} B / \mathrm{d} t$, kas yra sudettinga su indukcine apkrova. Šiame disertaciniame darbe buvo sukurti trys magnetinio lauko generatoriai skirti magnetoporacijos tyrimams. Norint preciziškiau ịvertinti sukurtų sistemų naujumą ir aktualumą, sukurti prototipai turi būti palyginti su prieš tai sukurtomis in vitro sistemomis (V. Novickij, Grainys, et al., 2017; V. Novickij, Grainys, Novickij, et al., 2014; V. Novickij et al., 2013; Van Bree et al., 2013; Xiong et al., 2018).

Matoma, kad pagrindinis pirmujų sistemų trūkumas (Novickij et al.) yra mažas kelių $\mu$ l efektyvus bandinio tūris, kuris apriboja biologinių eksperimentų vyk- 
dymą, tačiau toks tūris leido užtikrinti stiprių magnetinių laukų generavimą neviršijant $1 \mathrm{kA}$ srovès. Šios sistemos tinka tik pirminiams magnetoporacijos tyrimams, tačiau dèl Džaulio šilumos ir mažo efektyvaus tūrio pritaikymas yra ribotas. Labai išsiskiria Van bree et al. sistema, kuri skirta ypatingai aukšto $\mathrm{d} I / \mathrm{d} t$ impulsų formavimui. Ši sistema gali generuoti iki $10 \mathrm{kV} / \mathrm{cm}$ nehomogeniškus elekrinius laukus bandinyje bei pasižymi dideliu $(2 \mathrm{ml})$ bandinio tūriu.

2.1 lentelè. In vitro magnetoporacijai skirtų magnetinio lauko generatorių palyginimas

Table 2.1. Comparison of in vitro magnetic field generators for magnetoporation

\begin{tabular}{|c|c|c|c|c|c|c|}
\hline Generatorius & $B, \mathrm{~T}$ & $\begin{array}{l}\text { Bandinio } \\
\text { tūris, } \mu 1\end{array}$ & $\begin{array}{c}\text { Impulso } \\
\text { trukmé, } \\
\mu \mathrm{s}\end{array}$ & $\begin{array}{c}\text { Impulso } \\
\text { frontas, } \\
\mu \mathrm{s}\end{array}$ & $\begin{array}{l}\text { Dažnis, } \\
\mathrm{Hz}\end{array}$ & $\begin{array}{c}\text { Srovès } \\
\text { stipris, } \\
\text { kA }\end{array}$ \\
\hline $\begin{array}{l}\text { (V Novickij } \\
\text { et al., 2013) }\end{array}$ & $<5$ & 2,4 & $\sim 3$ & $\sim 1$ & Iki 40 & 0,55 \\
\hline $\begin{array}{l}\text { (Van Bree } \\
\text { et al., 2013) }\end{array}$ & $\begin{array}{c}\text { Nèra } \\
\text { duomenų }\end{array}$ & 2000 & $\sim 0,005$ & $\sim 0,006$ & Iki 50 & 1,25 \\
\hline $\begin{array}{l}\text { (V. Novickij, } \\
\text { Grainys, } \\
\text { Novickij, } \\
\text { et al., 2014) }\end{array}$ & $<10$ & 20 & $5-20$ & $\sim 2,5$ & Iki 200 & 1 \\
\hline $\begin{array}{l}\text { (V. Novickij, } \\
\text { Grainys, } \\
\text { et al., 2017) }\end{array}$ & $<5,5$ & 10 & $10-100$ & $\sim 2$ & Iki 100 & 0,9 \\
\hline $\begin{array}{l}\text { (Xiong et al., } \\
2018 \text { ) }\end{array}$ & 0,007 & $\begin{array}{c}\text { Nèra } \\
\text { duomenų }\end{array}$ & $\begin{array}{c}\mathrm{ms} \\
\text { ruožo }\end{array}$ & $\sim 50$ & $<100$ & 0,13 \\
\hline \multicolumn{7}{|c|}{ Šiame darbe sukurti generatoriai } \\
\hline $\begin{array}{l}\text { Markso } \\
\text { grandinė }\end{array}$ & 3,3 & 100 & $\sim 10$ & 0,450 & Iki 0,5 & 5,5 \\
\hline $\begin{array}{l}\text { Ignitrono } \\
\text { grandinè }\end{array}$ & 3 & 100 & $\sim 17$ & 0,640 & Iki 5 & 6,5 \\
\hline $\begin{array}{l}\text { Tiristorinè } \\
\text { grandinè }\end{array}$ & $<10$ & 50 & 10 & $\sim 2,5$ & Iki 5 & 1,5 \\
\hline
\end{tabular}

Tačiau, ši sistema yra bekontaktès elektroporacijos sistemos prototipas, kadangi magnetinio lauko komponentė yra neženkli, o indukuotas elektrinis laukas viršija ribinio elektrinio lauko amplitudes, kurios yra reikalingos klasikinei elektroporacijai. Magnetoporacijos tyrimuose abi poveikio komponentės (magnetinis ir elektrinis laukai) yra svarbios eksperimentiniam rezultatui. Dèl šios priežasties šiame darbe iš pradžių buvo sukurtas prototipas grịstas Markso grandine, kuris iš parametrinès pusės yra panašus lyginant su Van bree et al. sistema. 
Ivertinant, kad Markso grandinè su dielektrinio pramušimo raktais (kibirkštikliai) turi labai ribotas impulsų parametrų valdymo galimybes, šiame disertaciniame darbe buvo pasiūlytas magnetinio lauko generatorius su ignitrono raktu. Šis generatorius pasižymi pakankamu (iki $100 \mu \mathrm{l}$ ) efektyviu tūriu, palaiko aukštą $\mathrm{d} B / \mathrm{d} t$ impulsų formavimą (ko reikia magnetoporacijai) bei Džaulio šilumos įtaka yra sẻkmingai valdoma srovems viršijant kelis kA. Taip pat, šiame darbe buvo sukurta tiristorinè sistema, kuri yra tiesioginis (V. Novickij et al., 2013) sistemos patobulinimas - ženkliai padidintas bandinio tūris (nuo 2,4 iki $50 \mu \mathrm{l}$ ) bei trigubai padidinta komutuojama srovè. Impulsų pasikartojimo dažnis naujuose sistemose buvo apribotas iki $5 \mathrm{~Hz}$, kadangi nebuvo pastebèta ženklios šio parametro ịtakos magnetoporacijos procesui. Taip pat didesnis dažnis apsunkina temperatūros valdymą bandinyje.

\subsection{Antrojo skyriaus išvados}

1. Sub-mikrosekundinio fronto (450 ns), 3,3 T impulsiniai magnetiniai laukai sukelia detektuojamus biologinius pokyčius mielių ląstelèse.

2. Markso grandinès topologija su dielektrinio pramušimo raktais gali būti pakeista ignitronu sub-mikrosekundinio fronto impulsų generavimui, užtikrinant geresnị impulsų sekos parametrų valdymą.

3. Tiristoriniai puslaidininkiniai raktai tinka stiprių magnetinių laukų generatorių kūrimui ir magnetoporacijos tyrimams, tačiau dẻl srovès pokyčio per laiko vienetą $(\mathrm{d} I / \mathrm{d} t)$ ir Džaulio šilumos išsiskirančios induktoriuje, komutuojama srovè yra apribota kelių kA ruože, todèl reikia daugiau apvijų induktoriuose norint užtikrinti pakankamą magnetinio lauko amplitudę.

4. Daugiasluoksniai induktoriai tinka magnetoporacijos tyrimams, užtikrinant bent $3 \mathrm{~T}$ magnetinio srauto tankio amplitudę ir neviršijant $5{ }^{\circ} \mathrm{C}$ temperatūros pokyčių, tačiau indukuoto elektrinio lauko nehomogeniškumas yra pagrindinis tokių induktorių struktūros apribojimas. 


\section{Sukurtụ impulsinių induktorių analizè ir taikomieji magnetoporacijos tyrimai}

Šiame skyriuje nagrinejjama induktorių struktūros ir generuojamo magnetinio ir elektrinio lauko priklausomybès nuo apvijų skaičiaus, ritės tūrio, komutuojamo impulso formos. Analizei naudojamas COMSOL Multiphysics programų paketas. Taip pat skyriuje pateikiami eksperimentinių taikomujų magnetoporacijos tyrimų rezultatai. Skyriaus medžiagos pagrindu paskelbtos dvi publikacijos (V. Novickij et al., 2020; V. Novickij, Grainys, et al., 2017).

\subsection{Impulsinių induktorių parametrinè analizè}

Magnetoporacijos poveikiui sukelti reikalingas tinkamas generatorius, galintis suformuoti didelius $\mathrm{d} B / \mathrm{d} t$ impulsus. Nepriklausomai nuo impulsų formavimo grandinès, generatoriaus apkrova yra induktorius, tačiau induktoriaus struktūra gali skirtis, t. y. apvijų skaičius ir skerspjūvis, vidinis ir išorinis skersmuo bei ritès aukštis gali būti keičiami. İvertinant, paskelbtus mokslinius darbus šioje srityje ir išnagrinejjus naudotų induktorių struktūras, šiame skyriuje atliekama indukuoto transmembraninio potencialo analizè ir jo priklausomybè nuo impulso formos. Generuojamų magnetinio ir elektrinio laukų parametrų analizei naudojama 
COMSOL Multiphysics programinè įranga. Modeliams sudaryti pasitelktas simetrinis ašies atžvilgiu 2D modelis, o pats induktorius imituojamas kaip varinis įvairaus skerspjūvio laidas suvyniotas sluoksniais analogiškai modeliams, kurie yra pateikiami antrame skyriuje. Magnetoporacijos poveikiui charakterizuoti reikia ịvertinti generuojamų elektrinio ir magnetinio lauko amplitudes. Daugiasluoksnio induktoriaus struktūros pavyzdys ir naudojamo modelio tipinis rezultatas ( $\mathrm{I}=940$ A) yra pateikiami 3.1 paveiksle.

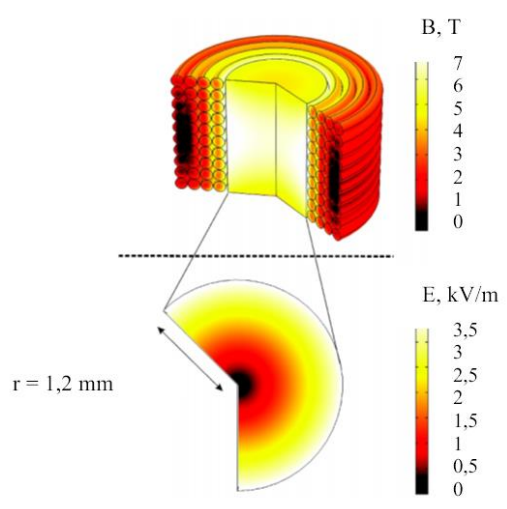

3.1 pav. Impulsinio magnetinio lauko (viršuje) ir indukuoto elektrinio lauko (apačioje) pasiskirstymas daugiasluoksniame induktoriuje (V. Novickij, Grainys, et al., 2017)

Fig. 3.1. The spatial distribution of magnetic field (top) and electric field (bottom) inside a multilayered inductor (V. Novickij, Grainys, et al., 2017)

Paveiksle 3.1 paveiksle pateikiami mažo tūrio induktoriaus $(\mathrm{r}=1,2 \mathrm{~mm})$ tipiniai elektrinio ir magnetinio lauko pasiskirstymai. Matoma, kad daugiasluoksnè struktūra leidžia generuoti homogenišką magnetinị lauką vidiniame induktoriaus tūryje, tačiau elektrinis laukas tiesiškai mažèja, tolstant nuo apvijų. Norint užtikrinti aukštą elektrinio lauko amplitudę ląstelių suspensijoje, panaudojant solenoidus, galima panaudoti fizinius ribotuvus kiuvetès viduje, fiziškai apribojant ląsteles erdvejje šalia apvijų. Tačiau, šiuo atveju reikia didinti induktorių efektyvų tūrị, kas įtakos ženklų energijos poreikio padidejjimą, norint pasiekti tas pačias amplitudes.

Taip pat technologiniai apribojimai neapsiriboja lauko homogeniškumu. Indukuoto elektrinio lauko amplitudè yra tiesiškai priklausoma nuo magnetinio lauko impulso $\mathrm{d} B / \mathrm{d} t$. Didinant induktoriaus apvijų skaičių bei keičiant formą, kartu keičiasi ir apkrovos induktyvumas, kas ženkliai ịtakoja generuojamų impulsų frontus. Tačiau, norint ịvertinti transmembraninio potencialo vertes ir tokiu būdu numatyti poveikị biologiniams objektams, buvo ištirtos antrame skyriuje naudotos ritès. 
Tyrimui naudotos dvi ritès keičiant vidinị tūrị ir vielos storị. Ričių parametrai:

- Ritè A: $6 \mathrm{~L} \times 8 \mathrm{~W}$, viela $\mathrm{d}=0,5 \mathrm{~mm}$, ritès $\mathrm{r}=2 \mathrm{~mm}$;

- Ritè C: $6 \mathrm{~L} \times 8 \mathrm{~W}$, viela $\mathrm{d}=0,8 \mathrm{~mm}$, ritès $\mathrm{r}=3 \mathrm{~mm}$, kur: $\mathrm{L}$ - ritès sluoksniai, W - apvijų skaičius. Ritès struktūra COMSOL aplinkoje pavaizduota 3.2 paveiksle.

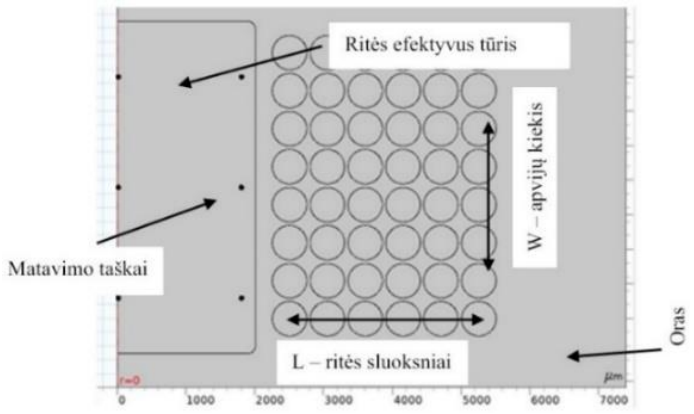

3.2 pav. Induktoriaus struktūra naudojama imitaciniame modelyje

Fig. 3.2. The structure of inductor in the model

Generuojamų laukų priklausomybei ištirti naudojami 3 skirtingų frontų srovès impulsai: $100 \mathrm{~ns}, 300 \mathrm{~ns}, 1000 \mathrm{~ns}$, šiame etape apsiribojant vienodo dydžio srove $\mathrm{I}_{\max }=1000 \mathrm{~A} \pm 30 \%$. Kadangi amplitudinis srovès dydis yra vienodas tarp ričių, pirmos ritès atveju numatomas iki $7 \mathrm{~T}$ magnetinis laukas, o antros ritès atveju tik apie $5 \mathrm{~T}$ dèl padidejusio ritès tūrio $(\mathrm{r}=3 \mathrm{~mm})$.

Imituojamų magnetinių impulsų forma pavaizduota 3.3 paveiksle. Matoma, kad impulso forma atitinka antrame skyriuje empiriškai gautų impulsų formą, tačiau dirbtinai sumažinta impulso trukmé, siekiant nustatyti tolimesni mokslinị pagrịstumą mažinti impulsų trukmę ir frontą magnetoporacijos tyrimuose.

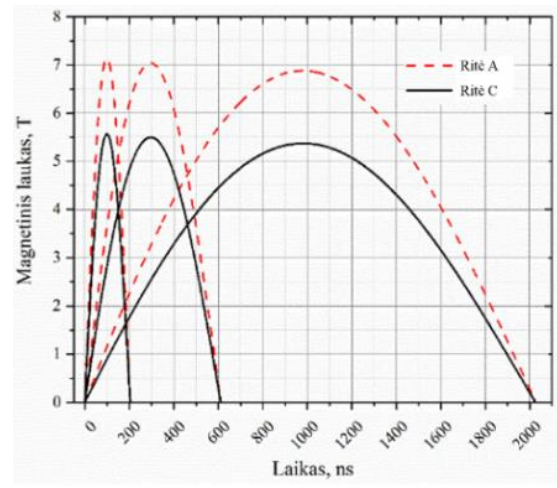

3.3 pav. Imituojamų magnetinio lauko impulsų forma

Fig. 3.3. The waveforms of modelled magnetic field pulses 
Indukuoto elektrinio lauko pikinès vertès priklausomybė nuo impulso fronto ir srovès ritei A pavaizduota 3.4 paveiksle. Matoma, kad indukuoto elektrinio lauko amplitudę galima didinti didinant srovę ir mažinant impulso frontą.

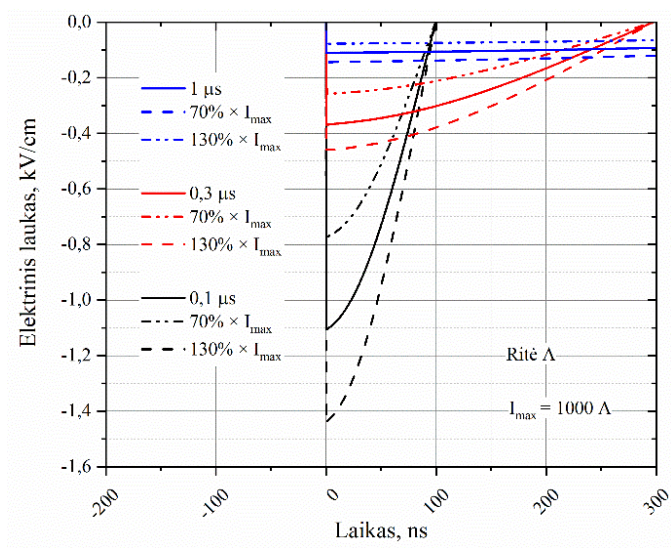

3.4 pav. Indukuoto elektrinio lauko priklausomybė nuo priekinio fronto ir srovès dydžio riteje A

Fig. 3.4. The dependence of induced electric field on the rise time and current amplitude in coil A

Analogiškas rezultatas gautas riteje C. Rezultatai pateikiami 3.5 paveiksle.

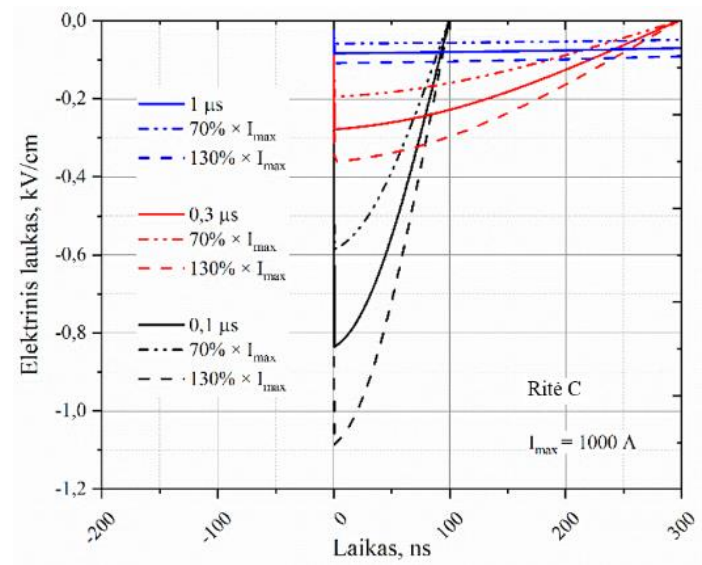

3.5 pav. Indukuoto elektrinio lauko priklausomybè nuo priekinio fronto ir srovès dydžio riteje $\mathrm{C}$

Fig. 3.5. The dependence of induced electric field on the rise time and current amplitude in coil C 
Kadangi ritè $\mathrm{C}$ yra didesnio tūrio, sukuriamas magnetinis ir atitinkamai indukuotas elektrinis laukas yra mažesni. Abejoms induktorių struktūroms naudojant „Comsol multiphysics“ buvo ịvertinta pikinè indukuoto transmembraninio potencialo vertè. Rezultatai pateikiami lentelèje 3.1. Analizei buvo naudojamas Krasowska analitinis modelis (Krassowska \& Filev, 2007).

3.1 lentelè. Transmembraninio potencialo priklausomybè nuo impulso fronto ir ritès

Table 3.1. The dependence of transmembrane potential on pulse rise time and coil

\begin{tabular}{|l|c|c|c|}
\hline Impulso fronto trukmé & $100 \mathrm{~ns}$ & $300 \mathrm{~ns}$ & $1000 \mathrm{~ns}$ \\
\hline Ritè A & $-0,25 \mathrm{~V}$ & $-0,14 \mathrm{~V}$ & $-0,055 \mathrm{~V}$ \\
\hline Ritè C & $-0,19 \mathrm{~V}$ & $-0,11 \mathrm{~V}$ & $-0,042 \mathrm{~V}$ \\
\hline
\end{tabular}

Matoma, kad sub-mikrosekundinio fronto impulsai leidžia indukuoti didesnị transmembranini potencialą, kas pagal elektroporacijos teoriją didina porų susidarymą, tačiau paskutiniai tyrimai (V. Novickij et al., 2020; V. Novickij et al., 2018) rodo, kad magnetoporacijos metu reikia pasiekti tik ribinị (kelių mV eilès) transmembraninị potencialą, kuris yra ženkliai mažesnis už lentelèje 3.1 pateiktas vertes. Naudojant šiame disertaciniame darbe sukurtą Markso generatorių taip pat nustatyta, kad stiprių magnetinių laukų impulsų fronto sumažinimas nèra efektyvus būdas pasiekti geresnę permeabilizaciją (V. Novickij et al., 2018). Tokius pačius arba net geresnius permeabilizacijos efektyvumus įmanoma pasiekti naudojant mikrosekundinius impulsus (V. Novickij et al., 2020; V. Novickij, Dermol, et al., 2017). Dẻl šių priežasčių viena iš pirminių disertacijos hipotezių apie sub-mikrosekundinių impulsų aktualumą pasiteisino tik dalinai.

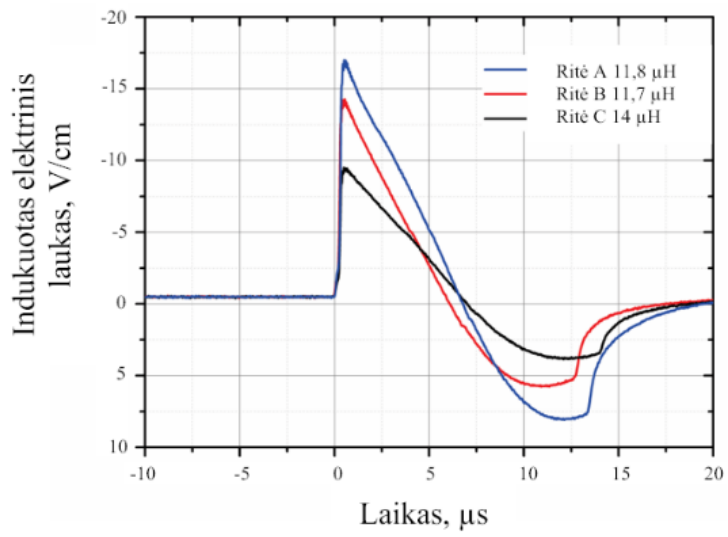

3.6 pav. Indukuoto elektrinio lauko impulso formos priklausomybè nuo induktoriaus (V. Novickij et al., 2020)

Fig. 3.6. The dependence of electric field pulse on inductor (V. Novickij et al., 2020) 
Ivertinant gaunamus rezultatus šio disertacinio darbo ribose nutarta apsiriboti trečiojo tiristorinio generatoriaus induktorių analize. Indukuoto elektrinio lauko impulso formos priklausomybè nuo induktoriaus pavaizduota 3.6 paveiksle.

Kadangi ritė A užtikrina didžiausią $\mathrm{d} B / \mathrm{d} t$ indukuotas elektrinis laukas yra taip pat didžiausias. Siekiant ịvertinti transmembraninị potencialą buvo naudojamas žinduolių ląstelès modelis grịstas poliarizacija. COMSOL aplinkoje buvo sudarytas 2D ašimetrinis modelis sudarytas iš laidžios sferos imituojančios citoplazmą $(0,5 \mathrm{~S} / \mathrm{m} ; 4 \mu \mathrm{m}$ spindulys $)$ ir plono $(5 \mathrm{~nm})$ mažo laidumo $\left(5 \times 10^{-7} \mathrm{~S} / \mathrm{m}\right)$ sluoksnio, kuris imituoja membraną.

Rezultatai yra pateikiami 3.7 paveiksle. Papildomai buvo ištirta ląstelès poliarizacijos priklausomybè nuo išorinès ląstelių terpès laidumo. Matoma, kad pikinè indukuotos ịtampos vertè siekia $10 \mathrm{mV}$, o išorinès terpès laidumas neturi ženklios įtakos šiam procesui. Toks rezultatas gautas, kadangi naudojami ilgesni negu $1 \mu$ s impulsai, kas viršija tipinès žinduolių ląstelès poliarizacijos konstantą.

Gauti rezultatai neprieštarauja rezultatams gautiems analitiškai skaičiuojant transmembraninị potencialą (Lucinskis et al., 2014).

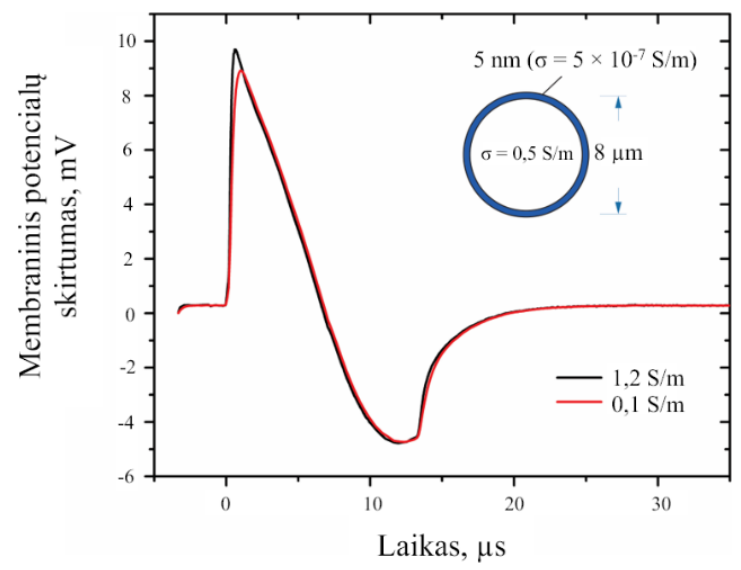

3.7 pav. Maksimalus transmembraninis potencialas impulso metu riteje A

Fig. 3.7. The peak transmembrane potential durin the pulse in coil A

Tačiau, akivaizdžiai matoma, kad indukuotos įtampos vertė yra daug mažesnè negu ribinès vertès, kurios yra deklaruojamos klasikinèje elektroporacijoje. Dèl šios priežasties vieningos nuomonès apie magnetoporacijos mechanizmą šiuo metu nèra. 


\subsection{Taikomieji magnetoporacijos tyrimai}

Taikomieji magnetoporacijos tyrimai buvo atlikti naudojant tiristorini generatorių ir ritę A. Eksperimentui buvo naudojamos Kinijos žiurkẻno kiaušidžių ląstelès (Europos autentiškų ląstelių kultūrų kolekcija ECACC, ląstelès CHO-K1, kat. Nr. 85051005, gautos tiesiogiai iš saugyklos), kurios buvo auginamos $25 \mathrm{~cm}^{2} \mathrm{kul}-$ tūrinèse kolbose (TPP, Šveicarija) HAM F-12 augimo terpejje (PAA, Austrija) 2-3 dienas inkubatoriuje (Kambič, Slovenija), esant $37{ }^{\circ} \mathrm{C}$ temperatūrai ir $5 \%$ $\mathrm{CO}_{2}$. Auginimo terpé (naudojama atliekant visus eksperimentus) buvo papildyta $10 \%$ serumo (Sigma Aldrich, Vokietija), L-glutamino (StemCell, Kanada) ir antibiotiku penicilino/streptomicino (PAA, Austrija) ir gentamicino (SigmaAldrichas, Vokietija). Eksperimentų dieną buvo paruošta ląstelių suspensija. Ląstelès buvo atskirtos $10 \times$ tripsino-EDTA (PAA, Austrija), praskiestos santykiu 1:9 Hanko bazinès druskos tirpale (StemCell, Kanada), ir tripsinizuotos. Ląstelès buvo perkeltos i $50 \mathrm{ml}$ mégintuvèli (TPP, Šveicarija) ir centrifuguotos 5 minutes $180 \mathrm{~g}, 22{ }^{\circ} \mathrm{C}$ temperatūroje. Supernatantas buvo pašalintas, o ląstelès buvo pakartotinai suspenduotos augimo terpèje HAM F12, esant ląstelių tankiui $10^{7}$ ląstelès $/ \mathrm{ml}$. Permeabilizacijai detektuoti ląstelių suspensija buvo sumaišyta su propidžio jodidu, kurio galutinè koncentracija buvo $136 \mu \mathrm{M}$. $40 \mu \mathrm{l}$ ląstelių ir dažo mišinio buvo perkelta ị $0,2 \mathrm{ml}$ PGR mėgintuvèli ir apdorota stipriu impulsiniu magnetiniu lauku.

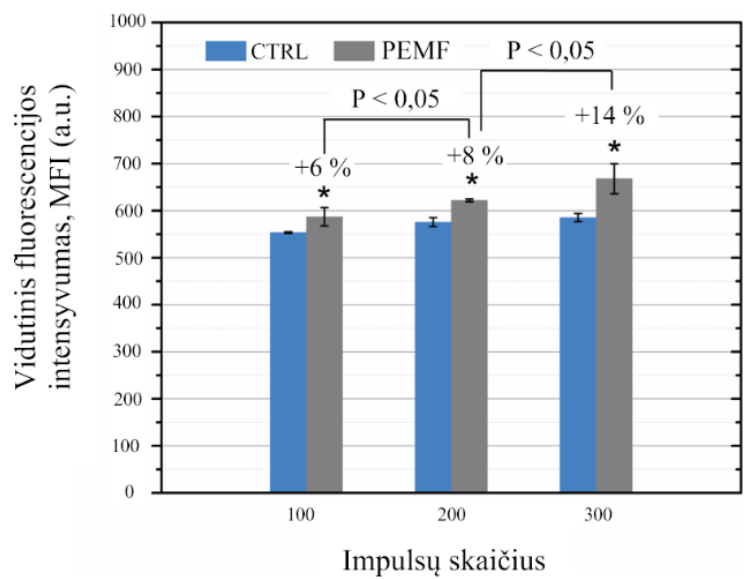

3.8 pav. CHO ląstelių magnetoporacija, čia CTRL - neveikta kontrolè;

PEMF - ląstelès veiktos stipriu impulsiniu magnetiniu lauku;

* - statistiškai patikimi $(\mathrm{P}<0,05)$ skirtumai (V. Novickij et al., 2020)

Fig. 3.8. Magnetoporation of CHO cells, where CTRL - untreated control;

PEMF - cells after magnetoporation; * - statistically significant differences $(\mathrm{P}<0.05)$

(V. Novickij et al., 2020) 
Generatorius buvo išbandytas, naudojant maksimalią ritès A amplitudę $(6,7 \mathrm{~T}, 17 \mathrm{~V} / \mathrm{cm})$, o 100, 200 ir 300 impulsų sekos buvo generuojamos naudojant $1 \mathrm{~Hz}$ pasikartojimo dažnį. Induktorius buvo pastoviai aušinamas ledu, tokiu būdu stabilizuojant temperatūrą.

Praejjus trims minutèms po paskutinio impulso, ląstelių suspensija buvo sumaišyta su PBS buferiu (10 mM KH2PO4 / K2HPO4) ir perkelta ị $5 \mathrm{ml}$ mėgintuvèlị (Sarsted, Vokietija) tolimesnei analizei naudojant tėkmès citometriją (Life Technologies, Attune NxT, JAV). Ląstelès buvo sužadintos lazeriu, esant $488 \mathrm{~nm}$ bangos ilgiui, ir skleidžiama fluorescencija buvo aptikta naudojant 574/26 nm juostos filtrą. Fluorescencija buvo nustatyta kaip vidutinè išmatuoto signalo (MFI) fluorescencijos vertè. Rezultatai yra apibendrinami 3.8 paveiksle.

Matoma, kad veikiant ląsteles stipriu magnetiniu lauku dideja ląstelès membranos pralaidumas fluorescenciniams dažams, kas parodo sèkmingą magnetoporaciją. Taip pat poveikis priklauso nuo impulsų skaičiaus.

Nustatyta, kad sukurtas generatorius, galintis komutuoti sroves iki 1,5 kA ir palaikantis induktyvias apkrovas $>5 \mu \mathrm{H}$ gali būti sẻkmingai taikytinas ląstelių permeabilizacijos eksperimentuose. Parodyta, kad 6,7 T, 17 V/cm mikrosekundinio diapazono impulsų pakanka magnetoporacijai sukelti in vitro. Nepaisant to, indukuoto transmembraninio potencialo amplitudè buvo vos $10 \mathrm{mV}$.

\subsection{Trečiojo skyriaus išvados}

1. Sub-mikrosekundinio fronto magnetinio lauko impulsai leidžia indukuoti didesnị transmembraninị potencialą ląstelèse, tačiau atsižvelgiant ì magnetoporacijos tyrimų rezultatus, magnetinių impulsų fronto mažinimas nèra efektyvus būdas padidinti magnetoporacijos efektyvumą.

2. Daugiasluoksniai induktoriai tinka magnetoporacijai sukelti, tačiau indukuoto elektrinio lauko erdvinis pasiskirstymas yra nehomogeniškas ir įtakoja skirtingą transmembraninio potencialo indukciją ląstelèse.

3. Tiristoriniais raktais grịstas impulsų generatorius, naudojant ritę A kaip apkrovą, tinka magnetoporacijai indukuoti žinduolių ląstelèse. 


\section{Bendrosios išvados}

1. Markso generatoriaus topologija tinka sub-mikrosekundinio fronto magnetinių impulsų generavimui ir yra taikytina magnetoporacijos srityje.

2. Sub-mikrosekundinio fronto magnetinių impulsų formavimo grandinè su ignitronu užtikrina impulsų sekos parametrų valdymą, lyginant su Markso topologijos generatoriumi.

3. Impulsų formavimo grandinè su ignitronu užtikrina pasikartojančių iki $5 \mathrm{kA}$ impulsų formavimą su 650-700 ns frontu, naudojant apkrovas artimas trumpajam jungimui.

4. Daugiasluoksniai induktoriai užtikrina pakankamą magnetinio lauko amplitudę ir temperatūros pokyčių valdymą, tačiau indukuoto elektrinio lauko nehomogeniškumas yra pagrindinis šios tipinės induktorių struktūros apribojimas.

5. Pasiūlytas stiprių magnetinių laukų generatorius su tiristoriniais raktais tinka magnetoporacijai indukuoti žinduolių ląstelèse, ląstelių suspensijos temperatūros pokyčiams neviršijant $5^{\circ} \mathrm{C}$. 



\section{Literatūra ir šaltiniai}

Abbatelli, L., Catalisano, G., \& Stella, C. G. (2018). Sic and silicon mosfet solution for high frequency dc-ac converters. PCIM Europe Conference Proceedings, 225809, $817-820$.

Achour, Y., \& Starzy, J. (2017). New Marx Generator Architecture With a Controllable Output Based on IGBTs. 45(12), 3271-3278.

Achour, Y., Starzynski, J., \& Lasica, A. (2018). New embedded nanosecond pulse generator based on spark gap and IGBT. IEEE International Pulsed Power Conference, 2017-June, 41-44. https://doi.org/10.1109/PPC.2017.8291324

Albuquerque, W. W. C., Costa, R. M. P. B., de Salazar e Fernandes, T., \& Porto, A. L. F. (2016). Evidences of the static magnetic field influence on cellular systems. Progress in Biophysics and Molecular Biology, 121(1), 16-28. https://doi.org/10.1016/j.pbiomolbio.2016.03.003

Amini, M., \& Ghoranneviss, M. (2016). Effects of cold plasma treatment on antioxidants activity, phenolic contents and shelf life of fresh and dried walnut (Juglans regia L.) cultivars during storage. LWT - Food Science and Technology, 73, 178-184. https://doi.org/10.1016/j.lwt.2016.06.014

Arias, P. D. M. A., \& Nunes, M. V. A. (2017). Analysis of the impact of the crowbar protection on short-circuit level and quality index. Renewable Energy and Power Quality Journal, 1(15), 813-818. https://doi.org/10.24084/repqj15.473 
Bae, J., Huh, M., Ryu, B., Do, J., Jin, S., \& Moon, M. (2011). Biomaterials The effect of static magnetic fi elds on the aggregation and cytotoxicity of magnetic nanoparticles. Biomaterials, 32(35), 9401-9414. https://doi.org/10.1016/j.biomaterials.2011.08.075

Bartkevi, S., \& Novickij, J. (2008). The Investigation of Stress Distribution in Pulsed Magnets. 7(7), 7-10.

Ben-Dov, N., Rozman Grinberg, I., \& Korenstein, R. (2012). Electroendocytosis Is Driven by the Binding of Electrochemically Produced Protons to the Cell's Surface. PLoS ONE, 7(11), 1-8. https://doi.org/10.1371/journal.pone.0050299

Beyer, R. A., \& Pesce-Rodriguez, R. A. (2004). The response of propellants to plasma radiation. 2004 12th Symposium on Electromagnetic Launch Technology, 273-278. https://doi.org/10.1109/elt.2004.1398089

Bhawandeep, U., Khachatryan, V., Sirunyan, A. M., Tumasyan, A., Adam, W., Asilar, E., Bergauer, T., Brandstetter, J., Brondolin, E., Dragicevic, M., Erö, J., Flechl, M., Friedl, M., Frühwirth, R., Ghete, V. M., Hartl, C., Hö Rmann, N., Hrubec, J., Jeitler, M., ... Woods, N. (2017). The CMS trigger system. Journal of Instrumentation. https://doi.org/10.1088/1748-0221/12/01/P01020

Bhonsle, S. P., Arena, C. B., Sweeney, D. C., \& Davalos, R. V. (2015). Mitigation of impedance changes due to electroporation therapy using bursts of high-frequency bipolar pulses. BioMedical Engineering Online, 14(Suppl 3), 1-14. https://doi.org/10.1186/1475925X-14-S3-S3

Bouda, N. R., Mina, M., \& Weber, R. J. (2014). High-current magnetic field generator for transcranial magnetic stimulation applications. IEEE Transactions on Magnetics, 50(11), 1-4. https://doi.org/10.1109/TMAG.2014.2325796

Brezar, S. K., Kranjc, M., Čemažar, M., Buček, S., Serša, G., \& Miklavčič, D. (2020). Electrotransfer of siRNA to silence enhanced green fluorescent protein in tumor mediated by a high intensity pulsed electromagnetic field. Vaccines. https://doi.org/10.3390/vaccines8010049

Budin, A. V., Pinchuk, M. E., Kuznetsov, V. E., Leont'ev, V. V., \& Kurakina, N. K. (2017). An experimental setup for investigation of arc and erosion processes in highvoltage high-current breakers. Instruments and Experimental Techniques, 60(6), 837-842. https://doi.org/10.1134/S0020441217060033

Calvet, C. Y., \& Mir, L. M. (2016). The promising alliance of anti-cancer electrochemotherapy with immunotherapy. Cancer and Metastasis Reviews, 35(2), 165- 177. https://doi.org/10.1007/s10555-016-9615-3

Cheng, X. B., Liu, J. L., Qian, B. L., Chen, Z., \& Feng, J. H. (2009). Research of a highcurrent repetitive triggered spark-gap switch and its application. IEEE Transactions on Plasma Science, 38(3 PART 2), 516-522. https://doi.org/10.1109/TPS.2009.2038381

Delshad, M. R., Rezanejad, M., \& Sheikholeslami, A. (2017). A New Modular Bipolar High-Voltage Pulse Generator. IEEE Transactions on Industrial Electronics, 64(2), 11951203. https://doi.org/10.1109/TIE.2016.2611460 
Dong, S., Yao, C., Yang, N., Luo, T., Zhou, Y., \& Wang, C. (2016). Solid-State Nanosecond-Pulse Plasma Jet Apparatus Based on Marx Structure with Crowbar Switches. IEEE Transactions on Plasma Science, 44(12), 3353-3360. https://doi.org/10.1109/TPS.2016.2627141

Dunlea, C., Xiao, C., \& Hirose, A. (2019). Co-axial Helicity Injection on the STOR-M Tokamak. 1-22. http://arxiv.org/abs/1909.12447

Dynex. (2013). DCR3980H85 Phase Control Thyristor. 2013(December), 1-10.

Eigenschaften, E. (2010). Datenblatt / Data sheet Datenblatt / Data sheet. 1-8.

El-Helw, S. R., Kozak, J. P., Burgos, R., Ngo, K., \& Boroyevich, D. (2018). Static and Dynamic Characterization of a $2.5 \mathrm{kV}$ SiC MOSFET. 2018 IEEE 6th Workshop on Wide Bandgap Power Devices and Applications, WiPDA 2018, 199-203. https://doi.org/10.1109/WiPDA.2018.8569044

Elgenedy, M. A., Massoud, A. M., Ahmed, S., \& Williams, B. W. (2018). A High-Gain, High-Voltage Pulse Generator Using Sequentially Charged Modular Multilevel Converter Submodules, for Water Disinfection Applications. IEEE Journal of Emerging and Selected Topics in Power Electronics, 6(3), 1394-1406. https://doi.org/10.1109/JESTPE.2017.2750244

Elserougi, A., Massoud, A., \& Ahmed, S. (2016). Conceptual study of a Bipolar modular high voltage Pulse generator with sequential charging. IEEE Transactions on Dielectrics and Electrical Insulation, 23(6), 3450-3457. https://doi.org/10.1109/TDEI.2016.005803

Firoozabadi, T. P., Ph, D., Shankayi, Z., Ph, D., Izadi, A., \& Ph, D. (2015). Can Lucifer Yellow Indicate Correct Permeability of Biological Cell Membrane under An Electric and Magnetic Field? 16(4), 560-563.

Ghodbane, S., Lahbib, A., Sakly, M., \& Abdelmelek, H. (2013). Bioeffects of Static Magnetic Fields : Oxidative Stress, Genotoxic Effects, and Cancer Studies. 2013.

Giesselmann, M., \& Loree, D. L. (1993). Results of lifetime testing of pulsed power switches using an electrolytic capacitor bank. IEEE International Pulsed Power Conference - Digest of Technical Papers, 2, 942-945.

Golberg, A., Sack, M., Teissie, J., Pataro, G., Pliquett, U., Saulis, G., Stefan, T., Miklavcic, D., Vorobiev, E., \& Frey, W. (2016). Energy-efficient biomass processing with pulsed electric fields for bioeconomy and sustainable development. Biotechnology for Biofuels, 9(1), 1-22. https://doi.org/10.1186/s13068-016-0508-Z

Grainys, A., Novickij, J., Stankevič, T., Stankevič, V., Novickij, V., \& Zurauskiene, N. (2015). Single Pulse Calibration of Magnetic Field Sensors Using Mobile 43 kJ Facility. Measurement Science Review, 15(5). https://doi.org/10.1515/msr-2015-0033

Grainys, Audrius, Novickij, J., Stankevič, T., Stankevič, V., Novickij, V., \& Zurauskiene, N. (2015). Single Pulse Calibration of Magnetic Field Sensors Using Mobile 43 kJ Facility. Measurement Science Review, 15(5), 244-247. https://doi.org/10.1515/msr2015-0033 
Gregory, K., Stevenson, P., \& Burke, R. (1998). Four-stage Marx generator using thyristors. Review of Scientific Instruments, 69(11), 3996-3997. https://doi.org/10.1063/1.1149221

Guenther, E., Klein, N., Mikus, P., Stehling, M. K., \& Rubinsky, B. (2015). Electrical breakdown in tissue electroporation. Biochemical and Biophysical Research Communications, 467(4), 736-741. https://doi.org/10.1016/j.bbrc.2015.10.072

Guerrero-Preston, R., Ogawa, T., Uemura, M., Shumulinsky, G., Valle, B. L., Pirini, F., Ravi, R., Sidransky, D., Keidar, M., \& Trink, B. (2014). Cold atmospheric plasma treatment selectively targets head and neck squamous cell carcinoma cells. International Journal of Molecular Medicine, 34(4), 941-946. https://doi.org/10.3892/ijmm.2014.1849

Hulangamuwa, W., Acharya, B., Chikan, V., \& Rafferty, R. J. (2020). Triggering Passive Molecular Transport into Cells with a Combination of Inhomogeneous Magnetic Fields and Magnetic Nanoparticles. ACS Applied Nano Materials. https://doi.org/10.1021/acsanm.9b02537

Jayanthi, P., \& Devaraj, D. (2019). Performance Study of DFIG Based Grid Connected WECS using Crowbar and Without Crowbar. IEEE International Conference on Intelligent Techniques in Control, Optimization and Signal Processing, INCOS 2019, 2019-2021. https://doi.org/10.1109/INCOS45849.2019.8951426

Jiang, C., Davalos, R. V., \& Bischof, J. C. (2015). A review of basic to clinical studies of irreversible electroporation therapy. IEEE Transactions on Biomedical Engineering, 62(1), 4-20. https://doi.org/10.1109/TBME.2014.2367543

Ka, A. (2009). Numerical Magneto-Mechanical Analysis of Destructive Coils with Reinforcement Cylinders of Various Thicknesses. 115(6), 2-3.

Kardos, T. J., \& Rabussay, D. P. (2012). Contactless magneto-permeabilization for intracellular plasmid DNA delivery in-vivo. Human Vaccines and Immunotherapeutics, 8(11), 1707-1713. https://doi.org/10.4161/hv.21576

Kardos, T. J., Rabussay, D. P., Kardos, T. J., \& Rabussay, D. P. (2016). intracellular plasmid DNA delivery in-vivo Contactless magneto-permeabilization for intracellular plasmid DNA delivery in vivo. 5515(March). https://doi.org/10.4161/hv.21576

Kluger, M. D., Epelboym, I., Schrope, B. A., Mahendraraj, K., Hecht, E. M., Susman, J., Weintraub, J. L., \& Chabot, J. A. (2016). Single-Institution Experience with Irreversible Electroporation for T4 Pancreatic Cancer: First 50 Patients. Annals of Surgical Oncology, 23(5), 1736-1743. https://doi.org/10.1245/s10434-015-5034-x

Kotnik, T., Frey, W., Sack, M., Haberl Meglič, S., Peterka, M., \& Miklavčič, D. (2015). Electroporation-based applications in biotechnology. Trends in Biotechnology, 33(8), 480-488. https://doi.org/10.1016/j.tibtech.2015.06.002

Kranjc, S., Kranjc, M., Scancar, J., Jelenc, J., Sersa, G., \& Miklavcic, D. (2016). Electrochemotherapy by pulsed electromagnetic field treatment (PEMF) in mouse melanoma B16F10 in vivo. Radiology and Oncology, 50(1), 39-48. https://doi.org/10.1515/raon-2016-0014 
Krassowska, W., \& Filev, P. D. (2007). Modeling electroporation in a single cell. Biophysical Journal. https://doi.org/10.1529/biophysj.106.094235

Lambricht, L., Lopes, A., Kos, S., Sersa, G., Préat, V., \& Vandermeulen, G. (2016). Clinical potential of electroporation for gene therapy and DNA vaccine delivery. Expert Opinion on Drug Delivery, 13(2), 295-310. https://doi.org/10.1517/17425247.2016.1121990

Langus, J., Kranjc, M., Kos, B., Šuštar, T., \& Miklavčič, D. (2016). Dynamic finiteelement model for efficient modelling of electric currents in electroporated tissue. Scientific Reports, 6(May), 1-11. https://doi.org/10.1038/srep26409

Liu, F., Liu, W., Zha, X., Yang, H., \& Feng, K. (2017). Solid-state circuit breaker snubber design for transient overvoltage suppression at bus fault interruption in low-voltage DC microgrid. IEEE Transactions on Power Electronics, 32(4), 3007-3021. https://doi.org/10.1109/TPEL.2016.2574751

Liu, Y., Fan, R., Zhang, X., Tu, Z., \& Zhang, J. (2019). Bipolar high voltage pulse generator without H-bridge based on cascade of positive and negative Marx generators. IEEE Transactions on Dielectrics and Electrical Insulation, 26(2), 476-483. https://doi.org/10.1109/TDEI.2018.007861

Lucinskis, A., Novickij, V., Grainys, A., Novickij, J., Tolvaisiene, S., \& Magnetic, H. (2014). Modelling the Cell Transmembrane Potential Dependence on the Structure of the Pulsed Magnetic Field Coils. 9-12.

Masood, S. (2017). Effect of Weak Magnetic Field on Bacterial Growth. Biophysical Reviews and Letters, 12(4), 177-186. https://doi.org/10.1142/S1793048017500102

McNutt, T., Olejniczak, K., Minden, S., Martin, D., Hayes, J., Wijenayake, A., \& Simco, D. (2018). Module and system considerations to maximize performance advantages of SiC power devices. Materials Science Forum, 924 MSF, 883-886. https://doi.org/10.4028/www.scientific.net/MSF.924.883

Merz, W., \& Grimes, M. (2012). Fast opening switch approach for high-voltage vacuum tube protection application. Proceedings of the 2012 IEEE International Power Modulator and High Voltage Conference, IPMHVC 2012, 308-311. https://doi.org/10.1109/IPMHVC.2012.6518741

Miklavčič, D., Mali, B., Kos, B., Heller, R., \& Serša, G. (2014). Electrochemotherapy: From the drawing board into medical practice. BioMedical Engineering Online, 13(1), 1-20. https://doi.org/10.1186/1475-925X-13-29

Modul, I., \& Daten, V. (2013). FZ3600R17HP4_B2 Technische Information / Technical Information FZ3600R17HP4 _B2.

Moonesan, M. S., Zhang, J. F., \& Jayaram, S. H. (2011). IGBT based HV pulse generator for high conductivity liquid food treatment. Digest of Technical Papers-IEEE International Pulsed Power 1160-1164. https://doi.org/10.1109/PPC.2011.6191574 
Muratori, C., Pakhomov, A. G., Xiao, S., \& Pakhomova, O. N. (2016). Electrosensitization assists cell ablation by nanosecond pulsed electric field in 3D cultures. Scientific Reports, 6(November 2015), 1-9. https://doi.org/10.1038/srep23225

Mwaniki, F. M., \& Vermeulen, H. J. (2019). Characterization and Application of a Pseudo-Random Impulse Sequence for Parameter Estimation Applications. IEEE Transactions on Instrumentation and Measurement, PP(c), 1-1. https://doi.org/10.1109/tim.2019.2937447

Neal, R. E., Garcia, P. A., Robertson, J. L., \& Davalos, R. V. (2012). Experimental characterization and numerical modeling of tissue electrical conductivity during pulsed electric fields for irreversible electroporation treatment planning. IEEE Transactions on Biomedical Engineering, 59(4), 1076-1085. https://doi.org/10.1109/TBME.2012.2182994

Novickij, J., Ka, R., Ka, A., Balevičius, S., Žurauskienė, N., \& Stankevič, V. (2004). Axial Magnetic Field Measurements of Pulsed Solenoids. 2(2), 15-20.

Novickij, V., Dermol, J., Grainys, A., Kranjc, M., \& Miklavčič, D. (2017). Membrane permeabilization of mammalian cells using bursts of high magnetic field pulses. PeerJ, 2017(4). https://doi.org/10.7717/peerj.3267

Novickij, V., Girkontaite, I., Zinkevičiene, A., Švediene, J., Lastauskiene, E., Paškevičius, A., Markovskaja, S., \& Novickij, J. (2017). Reversible Permeabilization of Cancer Cells by High Sub-Microsecond Magnetic Field. IEEE Transactions on Magnetics, 53(11). https://doi.org/10.1109/TMAG.2017.2719699

Novickij, V., Grainys, A., Lastauskiene, E., Kananavieiùte, R., Pamedytyte, D., Kalediene, L., Novickij, J., \& Miklaveìè, D. (2016). Pulsed Electromagnetic Field Assisted in vitro Electroporation: A Pilot Study. Scientific Reports, 6. https://doi.org/10.1038/srep33537

Novickij, V., Grainys, A., Novickij, J., \& Lucinskis, A. (2014). Programmable pulsed magnetic field system for biological applications. IEEE Transactions on Magnetics, 50(11). https://doi.org/10.1109/TMAG.2014.2323336

Novickij, V., Grainys, A., Švediene, J., Markovskaja, S., \& Novickij, J. (2014). Joule heating influence on the vitality of fungi in pulsed magnetic fields during magnetic permeabilization. Journal of Thermal Analysis and Calorimetry, 118(2). https://doi.org/10.1007/s10973-014-3735-1

Novickij, V., Stankevic, V., Grainys, A., Novickij, J., \& Tolvaisiene, S. (2015). Microsecond electroporator optimization for parasitic load handling and damping. Elektronika Ir Elektrotechnika, 21(6). https://doi.org/10.5755/j01.eee.21.6.13758

Novickij, V, Grainys, A., Lastauskien, E., Kananavi, R. I., Pamedytyt, D., Zinkevi, A. I., Kal, L., Novickij, J., Paškevi, A. I., \& Švedien, J. (2015). Growth Inhibition and Membrane Permeabilization of Candida lusitaniae Using Varied Pulse Shape Electroporation. 2015. 
Novickij, V, Grainys, A., \& Novickij, J. (2015). Magneto-Permeabilization of Viable Cell Membrane Using High Pulsed Magnetic Field. 02(c), 1-5. https://doi.org/10.1109/TMAG.2015.2439638

Novickij, V, Grainys, A., Novickij, J., Lucinskis, A., \& Zapolskis, P. (2013). Compact Microsecond Pulsed Magnetic Field Generator for Application in Bioelectronics. $i$, 25-28.

Novickij, Vitalij, Girkontaite, I., Zinkeviciene, A., Svediene, J., Lastauskiene, E., Paskevicius, A., Markovskaja, S., \& Novickij, J. (2017). Reversible Permeabilization of Cancer Cells by High Submicrosecond Magnetic Field. IEEE Transactions on Magnetics, 9464(c). https://doi.org/10.1109/TMAG.2017.2719699

Novickij, Vitalij, Grainys, A., Butkus, P., Tolvaišienė, S., Švedienė, J., Paškevičius, A., \& Novickij, J. (2016). High-frequency submicrosecond electroporator. Biotechnology and Biotechnological Equipment, 30(3), 607-613. https://doi.org/10.1080/13102818.2016.1150792

Novickij, Vitalij, Grainys, A., Lastauskiene, E., Kananavieiùte, R., Pamedytyte, D., Kalediene, L., Novickij, J., \& Miklaveìe, D. (2016). Pulsed Electromagnetic Field Assisted in vitro Electroporation: A Pilot Study. Scientific Reports, 6(September), 1-10. https://doi.org/10.1038/srep33537

Novickij, Vitalij, Zinkevičienè, A., Valiulis, J., Švedienè, J., Paškevičius, A., Lastauskienè, E., Markovskaja, S., Novickij, J., \& Girkontaitè, I. (2018). Different permeabilization patterns of splenocytes and thymocytes to combination of pulsed electric and magnetic field treatments. Bioelectrochemistry, 122(2017), 183-190. https://doi.org/10.1016/j.bioelechem.2018.04.006

Pawar, P., \& Patil, A. B. (2016). Electromagnetic Launcher. 563-567.

Pécastaing, L., Paillol, J., Reess, T., Gibert, A., \& Domens, P. (2006). Very Fast RiseTime Short-Pulse High-Voltage Generator. 34(5), 1822-1831.

Ponniran, A. Bin, Orikawa, K., \& Itoh, J. I. (2016). Fundamental operation of marx topology for high boost ratio DC-DC converter. IEEJ Journal of Industry Applications, 5(4), 329-338. https://doi.org/10.1541/ieejjia.5.329

Rabkowski, J., \& Platek, T. (2015). Comparison of the power losses in 1700V Si IGBT and $\mathrm{SiC}$ MOSFET modules including reverse conduction. 2015 17th European Conference on Power Electronics and Applications, EPE-ECCE Europe 2015. https://doi.org/10.1109/EPE.2015.7309444

Radhakrishnan, R., Diana, B., \& Kumari, R. (2012). Plant Physiology and Biochemistry Pulsed magnetic fi eld: A contemporary approach offers to enhance plant growth and yield of soybean. Plant Physiology et Biochemistry, 51, 139-144. https://doi.org/10.1016/j.plaphy.2011.10.017 
Rashitov, P., Vershanskiy, E., \& Gorchakov, A. (2019). Development of Control Algorithms to Ensure Optimal Thermal Modes of Semiconductor Switches in Distributed Static Synchronous Series Compensators. Proceedings - 2019 IEEE International Conference on Environment and Electrical Engineering and 2019 IEEE Industrial and Commercial Power Systems Europe, EEEIC/I and CPS Europe 2019. https://doi.org/10.1109/EEEIC.2019.8783647

Redondo, L. M., Kandratsyeu, A., \& Barnes, M. J. (2018). Marx Generator Prototype for Kicker Magnets Based on SiC MOSFETs. IEEE Transactions on Plasma Science, 46(10), 3334-3339. https://doi.org/10.1109/TPS.2018.2808194

Rems, L., \& Miklavčič, D. (2016). Tutorial: Electroporation of cells in complex materials and tissue. Journal of Applied Physics, 119(20). https://doi.org/10.1063/1.4949264

Rihan, M. (2018). Comparison among different crowbar protection techniques for modern wind farms under short circuit occurrence. 2017 19th International Middle-East Power Systems Conference, MEPCON 2017 - Proceedings, 2018-Febru(December), 1113-1121. https://doi.org/10.1109/MEPCON.2017.8301321

Rodaite-Riseviciene, R., Saule, R., Snitka, V., \& Saulis, G. (2014). Release of iron ions from the stainless steel anode occurring during high-voltage pulses and its consequences for cell electroporation technology. IEEE Transactions on Plasma Science, 42(1), 249254. https://doi.org/10.1109/TPS.2013.2287499

Rose, C. R., Crawford, M. T., Dale, G., Dighe, K., Johnson, J. B., Mccuistian, B. T., \& Taccetti, J. M. (2017). Multi-Pulse Diode-Isolated-Blumlein Induction-Cell Drivers. 2-4.

Scheffer, H. J., Nielsen, K., De Jong, M. C., Van Tilborg, A. A. J. M., Vieveen, J. M., Bouwman, A., Meijer, S., Van Kuijk, C., Van Den Tol, P., \& Meijerink, M. R. (2014). Irreversible electroporation for nonthermal tumor ablation in the clinical setting: A systematic review of safety and efficacy. Journal of Vascular and Interventional Radiology, 25(7), 997-1011. https://doi.org/10.1016/j.jvir.2014.01.028

Schoenbach, K. H., Pakhomov, A. G., Semenov, I., Xiao, S., Pakhomova, O. N., \& Ibey, B. L. (2015). Ion transport into cells exposed to monopolar and bipolar nanosecond pulses. Bioelectrochemistry, 103, 44-51. https://doi.org/10.1016/j.bioelechem.2014.08.015

Shankayi, Z., Firoozabadi, S. M. P., Mansourian, M., \& Mahna, A. (2014). The effects of pulsed magnetic field exposure on the permeability of leukemia cancer cells. Electromagnetic Biology and Medicine, 33(2), 154-158. https://doi.org/10.3109/15368378.2013.800103

Shankayi, Z., Firoozabadi, S. M. P., \& Mansurian, M. G. (2013). The Effect of Pulsed Magnetic Field on the Molecular Uptake and Medium Conductivity of Leukemia Cell. 211-216. https://doi.org/10.1007/s12013-012-9422-6

Skubis Jerzy, K. M. (2020). Analysis of the Possibility of Using Drill-Type Electrodes for Air Ionization. Applied Sciences, 10(11), 4030. 
Tamošiūnas, M., Mir, L. M., Chen, W. S., Lihachev, A., Venslauskas, M., \& Šatkauskas, S. (2016). Intracellular Delivery of Bleomycin by Combined Application of Electroporation and Sonoporation in Vitro. Journal of Membrane Biology, 249(5), 677689. https://doi.org/10.1007/s00232-016-9911-4

Tang, C., Lu, Y., \& Huang, T. (2018). Analysis on transient equivalent circuit of doubly fed induction generator with crowbar protection. 2017 2nd International Conference on Power and Renewable Energy, ICPRE 2017, 2, 208-213. https://doi.org/10.1109/ICPRE.2017.8390529

Thakur, S. K., \& Kumar, Y. (2018). Design development and testing of high voltage power supply with crowbar protection for IOT based RF amplifier system in VECC. Journal of Instrumentation, 13(5). https://doi.org/10.1088/1748-0221/13/05/T05009

Timmermans, R. A. H., Nierop Groot, M. N., Nederhoff, A. L., van Boekel, M. A. J. S., Matser, A. M., \& Mastwijk, H. C. (2014). Pulsed electric field processing of different fruit juices: Impact of $\mathrm{pH}$ and temperature on inactivation of spoilage and pathogenic microorganisms. International Journal of Food Microbiology, 173, 105-111. https://doi.org/10.1016/j.ijfoodmicro.2013.12.022

Towhidi, L., Firoozabadi, S. M. P., Mozdarani, H., \& Miklavcic, D. (2012). Lucifer Yellow uptake by $\mathrm{CHO}$ cells exposed to magnetic and electric pulses. 46(2), 119-125. https://doi.org/10.2478/v10019-012-0014-2

Van Bree, J. W. M., Geysen, J. J. G., Van Heesch, E. J. M., \& Pemen, A. J. M. (2013). Novel nanosecond pulsed electric field device for noncontact treatment of cells in native culture conditions. IEEE Transactions on Plasma Science, 41(10), 2654-2658. https://doi.org/10.1109/TPS.2013.2268321

Vechalapu, K., \& Bhattacharya, S. (2016). Performance comparison of 10 kV\#x2013;15 $\mathrm{kV}$ high voltage $\mathrm{SiC}$ modules and high voltage switch using series connected $1.7 \mathrm{kV} \mathrm{LV}$ SiC MOSFET devices. ECCE 2016 - IEEE Energy Conversion Congress and Exposition, Proceedings, 1(d). https://doi.org/10.1109/ECCE.2016.7855339

Wang, R., Song, H., Han, L., Yan, L., Wang, B., \& Zhao, P. (2019). Study on LVRT of DFIG wind power system based on crowbar protection circuit. 1st IEEE Student Conference on Electric Machines and Systems, SCEMS 2018, 5-10. https://doi.org/10.1109/SCEMS.2018.8624855

Xia, Y., Sun, J., Zhao, L., Zhang, F., Liang, X. J., Guo, Y., Weir, M. D., Reynolds, M. A., Gu, N., \& Xu, H. H. K. (2018). Magnetic field and nano-scaffolds with stem cells to enhance bone regeneration. Biomaterials, 183(June), 151-170. https://doi.org/10.1016/j.biomaterials.2018.08.040

Xiong, H., Sun, W., Liu, J., \& Shi, J. (2018). A multifunctional energy-saving magnetic field generator. Review of Scientific Instruments, 89(3). https://doi.org/10.1063/1.4990629

Yang, S., Zhou, T., Sun, D., Xie, Z., \& Zhang, X. (2016). A SCR crowbar commutated with power converter for DFIG-based wind turbines. International Journal of Electrical Power and Energy Systems, 81, 87-103. https://doi.org/10.1016/j.ijepes.2016.01.039 
Yao, J., Yang, M., \& Duan, Y. (2014). Chemistry, biology, and medicine of fluorescent nanomaterials and related systems: New insights into biosensing, bioimaging, genomics, diagnostics, and therapy. Chemical Reviews, 114(12), 6130-6178. https://doi.org/10.1021/cr200359p

Yarmush, M. L., Golberg, A., Serša, G., Kotnik, T., \& Miklavčič, D. (2014). Electroporation-Based Technologies for Medicine: Principles, Applications, and Challenges. Annual Review of Biomedical Engineering, 16(1), 295-320. https://doi.org/10.1146/annurev-bioeng-071813-104622

Yasu, K., Minamitani, Y., \& Nukaga, K. (2017). Development of high power burst pulse generator based on magnetic switch for bioelectrics application. 2016 IEEE International Power Modulator and High Voltage Conference, IPMHVC 2016, 392-396. https://doi.org/10.1109/IPMHVC.2016.8012802

Yatsugi, K., Nomura, K., \& Hattori, Y. (2018). Analytical Technique for Designing an RC Snubber Circuit for Ringing Suppression in a Phase-Leg Configuration. IEEE Transactions on Power Electronics, 33(6), 4736-4745. https://doi.org/10.1109/TPEL.2017.2731421

Zhang, J., Rees, F. L., Allen, S., Hull, B., Palmour, J. W., \& Casady, J. B. (2017). Impact of next-generation $1700 \mathrm{~V}$ SiC MOSFETs in a 125kW PV converter. 2017 IEEE Energy Conversion Congress and Exposition, ECCE 2017, 2017-January, 911-916. https://doi.org/10.1109/ECCE.2017.8095882 


\section{Autoriaus mokslinių publikacijų disertacijos tema sąrašas}

\section{Straipsniai recenzuojamuose mokslo žurnaluose}

Novickij V., Lastauskienė E., Švedienė J., Grainys A., Staigvila G., Paškevičius A., Girkontaitė I., Zinkevičienė A., Markovskaja S., Novickij J. (2018). Membrane permeabilization of pathogenic yeast in alternating sub-microsecond electromagnetic fields in combination with conventional electroporation. The Journal of Membrane Biology. (Clarivate Analytics Web of Science) 2018 Apr 1, 251(2), 189-195. http://doi.org/10.1109/TMAG.2020.2979120

Staigvila G., Novickij V., Novickij J. (2019). Fast ignitron-based magnetic field pulser for biological applications. IEEE Transactions on Magnetics. (Clarivate Analytics Web of Science) 2019 Mar 22, 55(5), 1-5. http://doi.org/10.1109/TMAG.2019.2902526

Novickij V., Grainys A., Staigvila G., Tolvaisiene S., Ustinavicius T., Novickij J. (2019) Design and optimization of pulsed magnetic field generator for cell magneto-permeabilization. Elektronika ir elektrotechnika. (Clarivate Analytics Web of Science) 2017 Apr 20, 23(2), 21-5. http://doi.org/10.5755/j01.eie.23.2.17994

Novickij V., Kranjc M., Staigvila G., Dermol-Černe J., Meleško J., Novickij J., Miklavčič D. (2020). High-Pulsed Electromagnetic Field Generator for Contactless Permeabilization of Cells In Vitro. IEEE Transactions on Magnetics. (Clarivate Analytics Web of Science) 2020 Mar 6, 56(5), 1-6. http://doi.org/10.1109/TMAG.2020.2979120 


\section{Straipsniai kituose leidiniuose}

Staigvila G., Novickij V. (2017), Concept of high $\mathrm{d} B / \mathrm{d} t$ pulse forming system for biological cell membrane permeabilization. In 2017 th IEEE Workshop on Advances in Information, Electronic and Electrical Engineering (AIEEE) 2017 Nov 24, 1-3. IEEE. 


\section{Summary in English}

\section{Introduction}

\section{Problem formulation}

Electroporation is a phenomenon of transient increase of permeability in biological cell membranes caused by a pulsed electric field. Electroporation has found many applications in biomedicine and biotechnology for delivery of drugs and genes into cells, tissue ablation, vaccination, food processing, biorefining, protein extraction, and many more. However, the generation of homogeneous electric fields requires electrodes, which is a major challenge when exposed to inhomogeneous biological objects and deep-grown tumors. The use of electrodes can lead to various electrochemical reactions between the electrode and the tissue.

Strong pulsed magnetic fields can also cause permeabilization of the cell membrane and, therefore, may be the solution to many of the described electroporation problems due to non-contact effects. However, in order to generate a sufficiently strong magnetic field, pulsed currents in the range of several hundred A to several kA must be applied, resulting in a problem of Joule heating and its control (Novickij et al., 2013). Accordingly, due to technological problems and engineering complexity, most of the works focusing on pulsed magnetic fields is limited to magnetic fields in the $\mu \mathrm{T}-\mathrm{mT}$ range or static magnetic systems up to 2 T (Bae et al., 2011; Radhakrishnan, Diana and Kumari, 2012; Ghodbane et al., 2013). Pulsed fields of such parameters have limited application for cellular plasma membrane permeability control, which can be induced using $>2 \mathrm{~T}$ pulsed magnetic fields 
(V. Novickij, Grainys, et. al., 2014; V. Novickij, Grainys, et. al. 2014; Kardos et al., 2016).

However, during contactless magnetic field-induced cell permeabilization, several exposure components must be considered: 1) pulsed magnetic field parameters; 2) parameters of the induced electric field and 3) thermal influence due to Joule heating, evaluating the influence of each of the components. Finally, to date, the mechanism of magnetic fieldinduced permeabilization is unknown, although the mechanism is thought to be similar to traditional electroporation.

Due to these reasons, the topic requires further research and technological development, which has the potential to ensure the development and application of new methods to increase cell membrane permeability in biomedicine or biotechnology.

\section{Relevance of the thesis}

There is currently a lack of magnetic field pulse systems that can be used in cell membrane permeability studies. For these reasons, the phenomenon of cell permeabilization itself has not been adequately studied, and its application is in most cases limited to preclinical studies. The introduction of new technological solutions in this field could potentially increase the availability and popularity of this technology, thus encouraging further research in the field.

\section{Object of research}

The object of the research is high-power pulsed electromagnetic field systems and their design methods for the formation of sub-microsecond and microsecond rise-time pulses for control of the permeability of cell membranes.

\section{The aim of the thesis}

The aim of this work is to develop magnetic field generators that, without direct contact with the sample, can cause changes in the permeability of cell membranes.

\section{Tasks of the thesis}

In order to achieve the aim of the thesis, the following tasks need to be solved:

1. To investigate high power pulse technologies and propose magnetic pulse generating circuits for high magnetic field variation per unit time for controlling the permeability of biological cell membranes without direct contact with the sample.

2. To evaluate the structure of pulsed inductors, the distributions of the induced electric field, the heating effects and ensure the stabilization of the temperature during exposure.

3. To perform applied experimental investigation of the developed generators, showing the transfer of fluorescent dyes across the membrane of biological cells. 


\section{Research methodology}

Finite element method simulation methods are used in the work, electronic circuits are designed, circuit research is performed, applied tests are performed with different types of cells.

\section{Scientific novelty of the thesis}

During the preparation of the dissertation, the following results significant for electrical and electronic engineering science were obtained:

1. Simulation models of pulse inductors were developed and target field parameters for cell membrane permeability control experiments were determined.

2. A Marx topology-based magnetic field generator has been developed to generate magnetic pulses of $3.3 \mathrm{~T}$ with $450-500 \mathrm{~ns}$ rise time in a volume of 100 $\mu 1$, and is applicable in magnetoporation studies.

3. Developed ignitron-based pulse generating circuit is capable of generating up to 3 T magnetic field pulses with $650-700$ ns rise time in a volume of $100 \mu \mathrm{l}$, ensuring pulse amplitude and frequency control.

4. A new pulse generator with a thyristor-based pulse generating circuit is capable of generating microsecond duration (10-15 $\mu$ s) magnetic field pulses up to $10 \mathrm{~T}$ in a $50 \mu \mathrm{l}$ volume, providing pulse amplitude and frequency control, and is applicable for magnetoporation studies.

\section{Practical value of research findings}

The results of the research can be used for further research in the field of magnetoporation and contribute to the development of understanding and methodology of this biological phenomenon. The results of the work were also used in the implementation of the Future Technology Program project LAT-16001, "Electro-magnetoporation mediated biocontrol of the microgravity affected and skin infections causative microorganisms".

\section{Defended statements}

1. A 3.3 T sub-microsecond rise-time pulse system based on a Marx generator is applicable in magnetoporation studies and ensures the generation of an induced electric field in the cell suspension of up to $0.2 \mathrm{kV} / \mathrm{cm}$ without exceeding $3{ }^{\circ} \mathrm{C}$ temperature changes in the effective volume of the inductor.

2. The developed pulse generating circuit using ignitron ensures the generation of repetitive pulses up to $5 \mathrm{kA}$ with a 650-700 ns rise time, using loads close to short circuit and can be used for high $\mathrm{d} B / \mathrm{d} t$ magnetic pulse generation.

3. A thyristor-based magnetic field generator can generate $(10-15 \mu \mathrm{s})$ microsecond pulses up to $10 \mathrm{~T}$ and is suitable for inducing increased cell membrane permeability, while the temperature does not exceed $5^{\circ} \mathrm{C}$ in the effective volume of the inductor. 


\section{Approval of the research findings}

5 articles were published on the topic of the dissertation: four in scientific journals included in the list of Clarivate Analytics Web of Science (Novickij 2017, Novickij 2018, Staigvila 2019, Novickij 2020) with an impact factor, one - in conference proceedings (Staigvila 2017) included in Clarivate Analytics Web of Science database.

The results of the research conducted in the dissertation were presented in eight scientific conferences in Lithuania and abroad:

- Conference of Young Scientists "Electronics and Electrical Engineering" 2017, 2018, 2019. In Vilnius;

- International Conference "Open Readings" 2017, 2019, Vilnius;

- International Conference "Electronics" 2017, Palanga;

- International Conference "The 5th IEEE Workshop on Advances in Information, Electronic and Electrical Engineering AIEEE'2017 2017, Riga;

- International Conference "The 3rd World Congress on Electroporation and Pulsed Electric Fields in Biology, Medicine, and Food \& Environmental Technologies" 2019, Toulouse.

\section{Structure of the dissertation}

The dissertation consists of an introduction, three chapters and a summary in English. There are also 3 annexes.

The volume of the work is 82 pages, 37 figures and 4 tables. 104 literature sources were used in writing the dissertation.

\section{Literature overview of magnetic field generation technologies and applications}

In recent years, a non-contact method based on pulsed magnetic fields for reversible and irreversible membrane permeabilization of biological cells has been proposed (Kardos et al., 2012; Kranjc et al., 2016). By exposing cells to pulsed magnetic fields, their membrane becomes conductive to fluorescent markers (Towhidi et al., 2012). The method could be used as an alternative to electroporation, where pulsed electric fields are used to change membrane permeability (Yarmush et al., 2014; Kotnik et al., 2015). It is currently thought that a pulsed magnetic field induces an electric field and thus polarizes the cell membrane, which affects pore formation similarly to electroporation (Towhidi et al., 2012; Kranjc et al., 2016). However, the electric field induced by a rapidly changing magnetic field is several orders of magnitude smaller than the electric field required for electroporation (Lucinskis et al., 2014; V. Novickij, Grainys, et al., 2016; V. Novickij, Dermol, et al. 2017). As a result, other influencing phenomena such as electrophoresis (Schoenbach et al., 2015), cell receptor activation (Shankayi et al., 2014), electroendocytosis (Ben-Dov, Rozman Grinberg et al., 2012), or magnetomotive forces are also considered. (Yao, Yang and Duan, 2014), although it is still not possible to unambiguously determine the mechanism of action. It has also been found that single pulses up to $16.4 \mathrm{~T}$ do not cause detectable cell permeabilization, but application of $2.9 \mathrm{~T}$ pulses (but higher $\mathrm{d} B / \mathrm{d} t$ ) results in a cellular response (Towhidi et al., 2012; Shankayi, Firoozabadi and Man- 
surian, 2013; Novickij, Grainys and Novickij, 2015). The low cell permeabilization efficiency is thought to be due to the small induced electric field, which was below $1 \mathrm{kV} / \mathrm{cm}$ in all cases.

Magnetoporation was also confirmed by in vivo delivery of a green fluorescent plasmid into muscle (Kardos et al., 2016) or cisplatin into tumors (Kranjc et al., 2016), which is comparable in efficiency to conventional electroporation. In vitro studies investigating magnetoporation techniques also demonstrate that cell permeabilization can be achieved; however, treatment efficacy is several times lower compared to electroporation (Towhidi et al., 2012; Firoozabadi et al., 2015; V. Novickij et al., 2015). Finally, it has been found that the induced electric field cannot be considered as the only parameter responsible for membrane permeability during magnetoporation (V. Novickij et al., 2016).

Based on existing research, it can be argued that microsecond-length magnetic pulses with steep rise-time are more adaptable in magnetoporation, therefore, there is a need to develop high $\mathrm{dB} / \mathrm{dt}$ magnetic field systems (Towhidi et al., 2012; Kardos et al., 2016; V. Novickij, Dermol, Grainys, et al., 2017; V. Novickij, Girkontaite, Zinkevičiene, et al. 2017).

The generation of strong magnetic fields requires kA series currents, but this creates engineering and technological problems for formation of high-power pulses. To generate such a pulse, high power switches are needed that can transfer all the energy stored in the capacitors into a load (in the case of magnetoporation, an inductor). Also, in the context of magnetoporation, the $\mathrm{d} V / \mathrm{d} t$ and $\mathrm{d} I / \mathrm{d} t$ of such switches must be large enough (Hulangamuwa et al., 2020) to ensure sufficient electric field induction. High power switches can be divided into dielectric breakdown or semiconductor ones (Vechalapu and Bhattacharya, 2016). In order to build a system various pulse forming circuit topologies can be used, which can involve both the dielectrical breakdown and semiconductor switches, however, the device should be able to drive predominantly inductive loads.

To summarize, the application of strong magnetic fields in the biomedical and biotechnological sciences can cause a controlled increase in the permeability of the plasma membrane of a cell, but requires high-power systems whose amplitude of magnetic field pulses exceeds a few $\mathrm{T}$. In in vitro studies, high $\mathrm{d} B / \mathrm{d} t$ systems have been shown to be desirable due to the induced biological effects in the cell membrane due to the increased efficiency of electromagnetic transfer. The development of pulsed inductors for magnetoporation studies requires the modification of their structure and effective volume in such a way as to reduce the influence of thermal processes and ensure the most homogeneous effect on cells.

Various types of semiconductor and dielectric breakdown switches are suitable for the development of magnetoporation systems, but a compromise must be reached between the dynamical characteristics of the switches, the transient circuits and control complexity, and the maximum pulse parameters. Marx generator circuit topology, IGBT and MOSFET key arrays and dielectric breakdown-based systems are suitable for high power pulse generation using inductive load. 


\section{Development and research of high power pulse generators}

In magnetoporation works, there is no consensus on the amplitude or pulse shape of a pulsed magnetic field, although this affects the efficiency of induced cell permeabilization. Therefore, in this work, using a typical Marx generator topology and spark gaps, a high $\mathrm{d} B / \mathrm{d} t$ generator was developed to evaluate the target parameters for the final prototype.

The Marx generator consisted of 6 stages (total voltage $23 \mathrm{kV}$, stage voltage $3.85 \mathrm{kV}$ ). $0.15 \mu \mathrm{F}$ capacitors (Cornell Dubilier, SC, USA) are used in each stage. An inductor (coil) is used for the load of the generator (2 layers, 6 windings with a total inductance of $1.1 \mu \mathrm{H})$. The inductor was designed to accommodate a $0.2 \mathrm{ml} \mathrm{PCR}$ sterile tube (Quali, SC, USA) for biological samples. The energy of one pulse was in the range of 6 to $7 \mathrm{~J}$. The basic scheme of the generator and the resulting magnetic field pulse are shown in Figure S2.1.

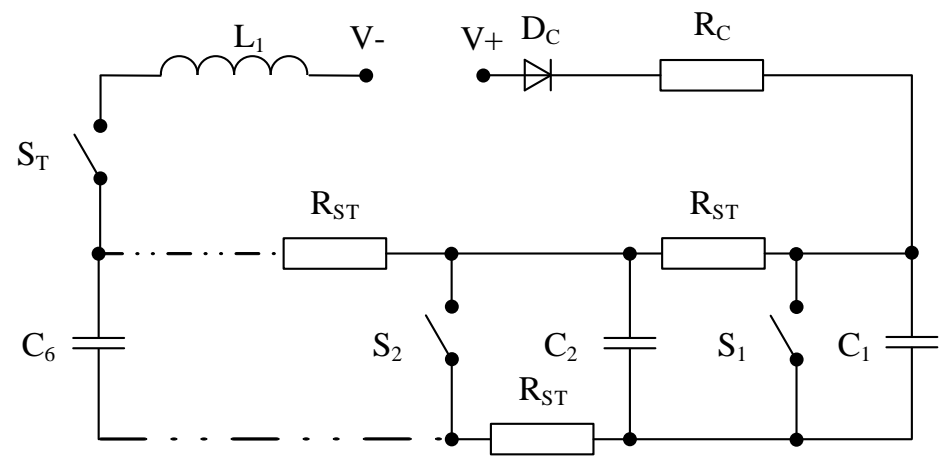

Fig. S2.1. Marx generator topology and resultant magnetic field pulses

(V. Novickij, Lastauskiene, et al., 2017)

Assuming that the induced electric field has a significant influence for the biological effect, the peak amplitude of the induced electric field was up to $0.19 \mathrm{kV} / \mathrm{cm}$ due to the high $\mathrm{d} B / \mathrm{d} t$ (rise-time $450 \mathrm{~ns}$ ).

The induced electric field is hundreds of times greater than the typical electric field amplitudes used in magnetoporation works. The total pulse duration is about $12 \mu \mathrm{s}$, but the homogeneity of the magnetic and electric fields must also be assessed to assess the effect on the cells. COMSOL Multiphysics (COMSOL, Stockholm, Sweden) was used to achieve this goal. Inductor model, spatial distributions of magnetic and induced electric field are shown in Figure S2.2.

After determining the pulse parameters, applied studies of a Marx topology-based generator with yeast cells were performed. The experiments were performed using conventional electroporation and magnetoporation separately and together to determine possible synergistic effects. A rectangular pulse generator (V. Novickij, Grainys, Butkus, et al., 2016) and a $1 \mathrm{~mm}$ gap cell (VWR International, Radnor, USA) were used for electroporation. Yeast Candida albicans (ATCC14053) was selected for the study. 


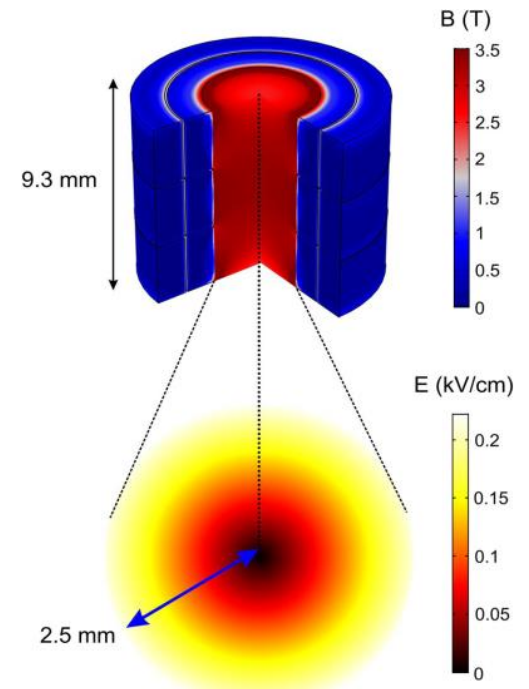

Fig. S2.2. Spatial distribution of pulsed magnetic (top) and induced electric field (bottom) in the inductor (V. Novickij, Lastauskiene, et al., 2017)

The effect was investigated by evaluating yeast permeabilization after magnetoporation and electroporation. Permeabilization efficiency was assessed by fluorescent staining (PI, propidium iodide) using flow cytometry (mean fluorescence level, number of fluorescent cells). The results are presented in Fig. S2.3.

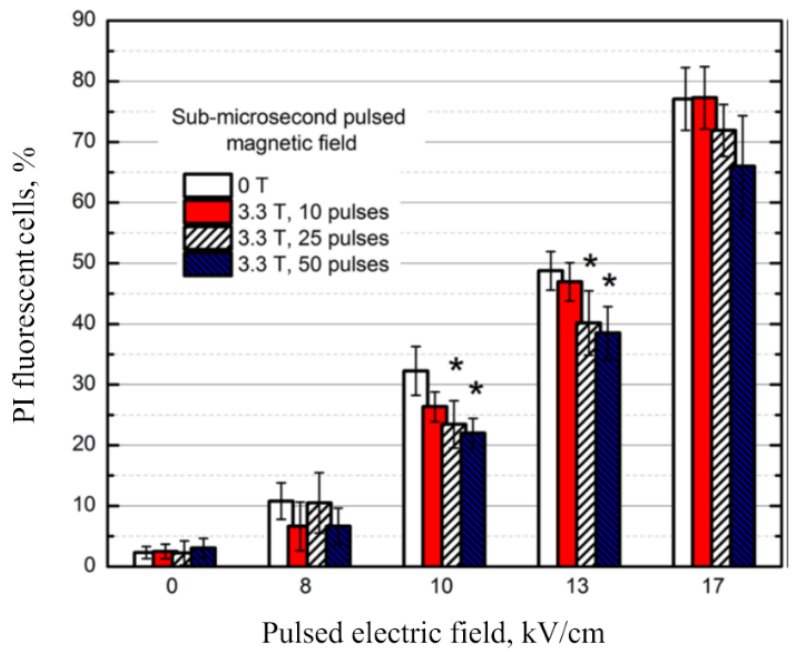

Fig S2.3. Permeability of $C$. albicans to propidium iodide after pulsed exposure, where an asterisk (*) indicates a statistically significant $(\mathrm{P}<0.05)$ difference compared to electroporation (V. Novickij, Lastauskiene, et al., 2017) 
It can be seen that the yeast is resistant to magnetoporation of the indicated parameters and the differences between the control and the samples after exposure to the pulsed magnetic field are statistically insignificant. However, exposure of yeast to an electric field shows an increase in the number of permeabilized cells. Combining magnetoporation and electroporation showed a statistically significant $(\mathrm{P}<0.05)$ difference, but contrary to expectations, a decrease in the number of permeabilized cells was seen. Experimental tests have shown that the generator of the specified parameters can be used to induce detectable changes in yeast cells.

Nevertheless, use of spark gaps to generate kA range pulses is not convenient due to the degradation of the electrodes and poor control of pulsing parameters. Therefore, further in the study, a generator based on ignitron switch for generation of pulses similar to the Marx generator topology has been developed. The circuit is presented in Fig. S2.4.

The main power supply circuit of the generator consists of a constant high voltage power supply $8 \mathrm{kV}$ Spellman and capacitors $\mathrm{C} 120 \mu \mathrm{F}$ and $\mathrm{C}_{\mathrm{DIS}} 0.75 \mu \mathrm{F}$. Energy is stored in capacitors C1, but due to the need for repetitive pulses, Cornell Dubilier capacitors are used in addition. Resistor R1 $1880 \Omega$ is used for current limitation and protection of high voltage $8 \mathrm{kV}$ source against short circuit during discharge.

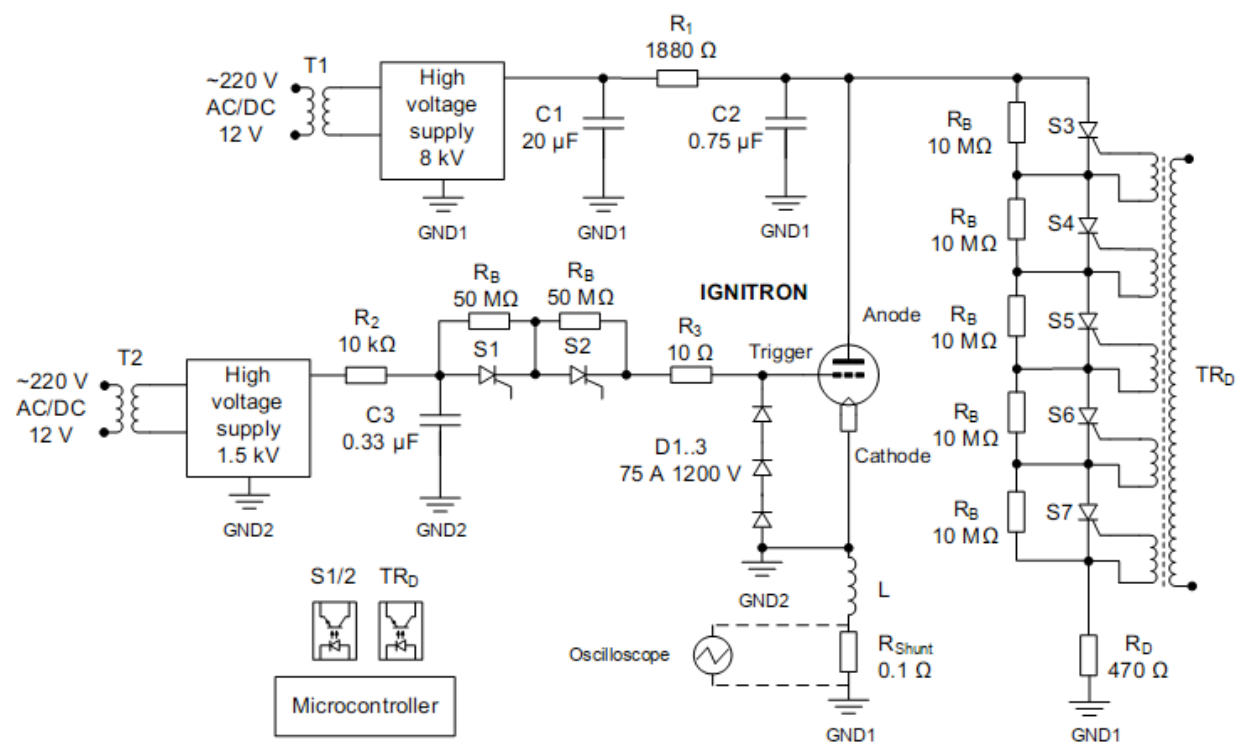

Fig. S2.4. Structural scheme of the ignitron-based magnetic field generator

(Staigvila et al., 2019)

The emergency discharge circuit is designed so that the energy stored in the capacitors $C 1$ and $C_{D I S}$ can be discharged in resistance $R_{D} 470 \Omega$. The circuit consists of four thyristors SCR (D1-4), and their parallel resistances $R_{B} 10 \mathrm{M} \Omega$. The protection circuit 
operates independently from the rest of the generator circuit and is controlled by a transformer and a physical button. The prototype control and power circuits are galvanically isolated. Coil L is used as a load in the generator. Pulse shape measurements are performed on a series resistor $\mathrm{R}_{\text {Shunt }} 0.1 \Omega$. An experimental prototype of the generator is shown in Fig. S2.5.

The developed pulse generator is based on an Ignitron (NL-1038, National Electronics, Farmingdale, NY, USA) type switch.

The generator is controlled by a microcontroller XMEGA128A3U (Atmega, San Jose, CA, USA), which is galvanically separated by a controller ADUM4223ARWZ (Analog Devices, Norwood, MA, USA).

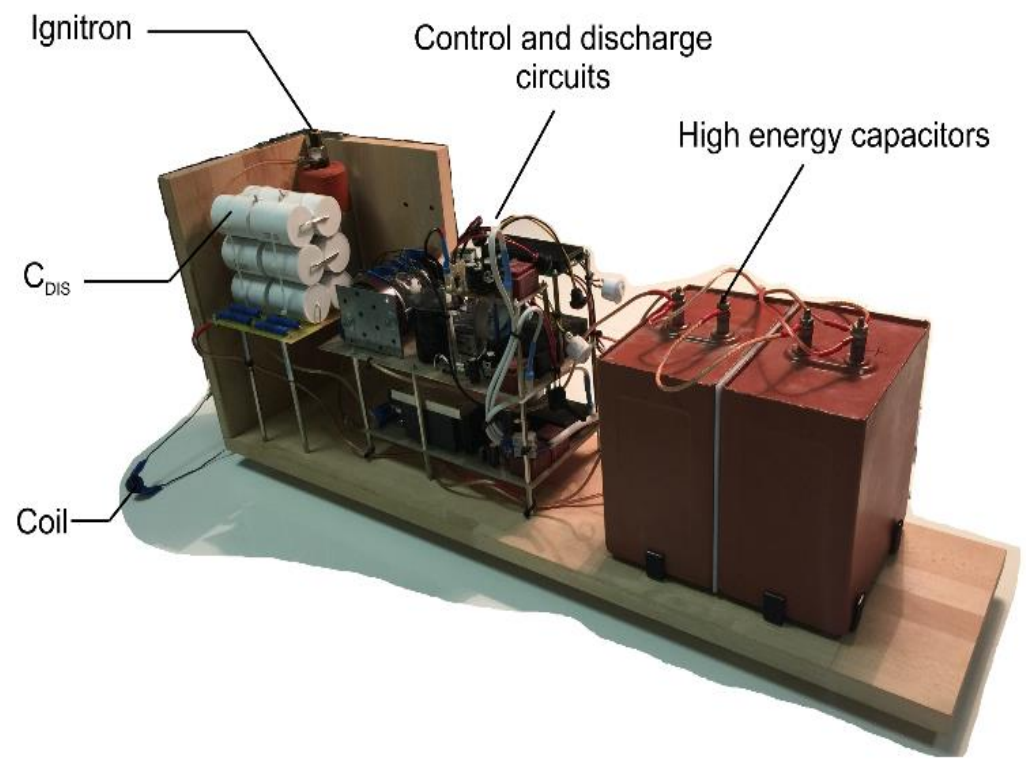

Fig. S2.5. Photo of the ignitron-based generator prototype

(Staigvila et al., 2019)

A coil (two layers, six windings and $\mathrm{L}=1.4 \mu \mathrm{H}$ ) was used as the load for the generator test. A high cross-section of enameled copper wire $\left(1.5 \times 2 \mathrm{~mm}^{2}\right)$ was used. A $2.4 \Omega$ resistor was also used as a load for comparison. The shapes of the respective pulses are shown in Fig. S2.6. 


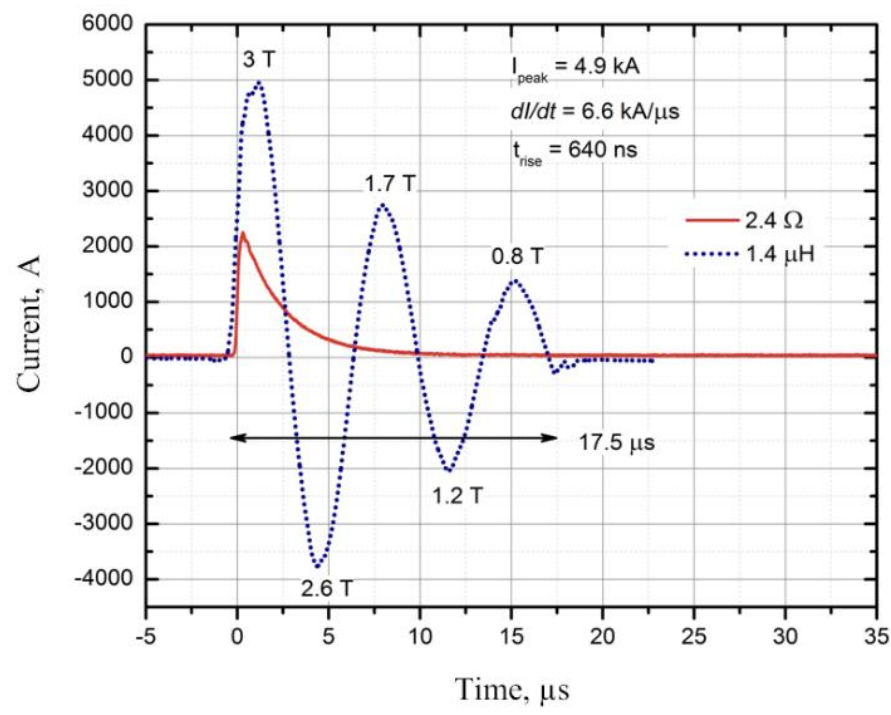

Fig. S2.6. The waveforms of the generator using inductive and resistive loads (Staigvila et al., 2019)

It can be seen that the generator can generate high power pulses with a sub-microsecond rise-time $(640 \mathrm{~ns}$ at $\mathrm{L}=1.4 \mu \mathrm{H})$, which ensures high $\mathrm{d} B / \mathrm{d} t$ rate and thus allows to induce a sufficient electric field for magnetoporation studies. The highest value of the generated current pulse is $4.9 \mathrm{kA}$, when the charging voltage was $6.5 \mathrm{kV}$, and the maximum $\mathrm{d} I / \mathrm{d} t$ was $6.6 \mathrm{kA} / \mu \mathrm{s}$. An RC pulse signal was also generated during the test to make sure that the ignitron is generating microsecond pulses regardless of the type of load.

Considering that there is no consensus on the influence of individual exposure components in the magnetoporation studies, a third pulse system was developed within this work to generate repetitive pulses up to $10 \mathrm{~T},>10 \mathrm{~V} / \mathrm{cm}$. Two MCC255-16io1 (IXYS, USA) thyristor (SCR) modules S1 and S2 were used for pulse generation. The structure of the generator is shown in Fig. S2.7. 


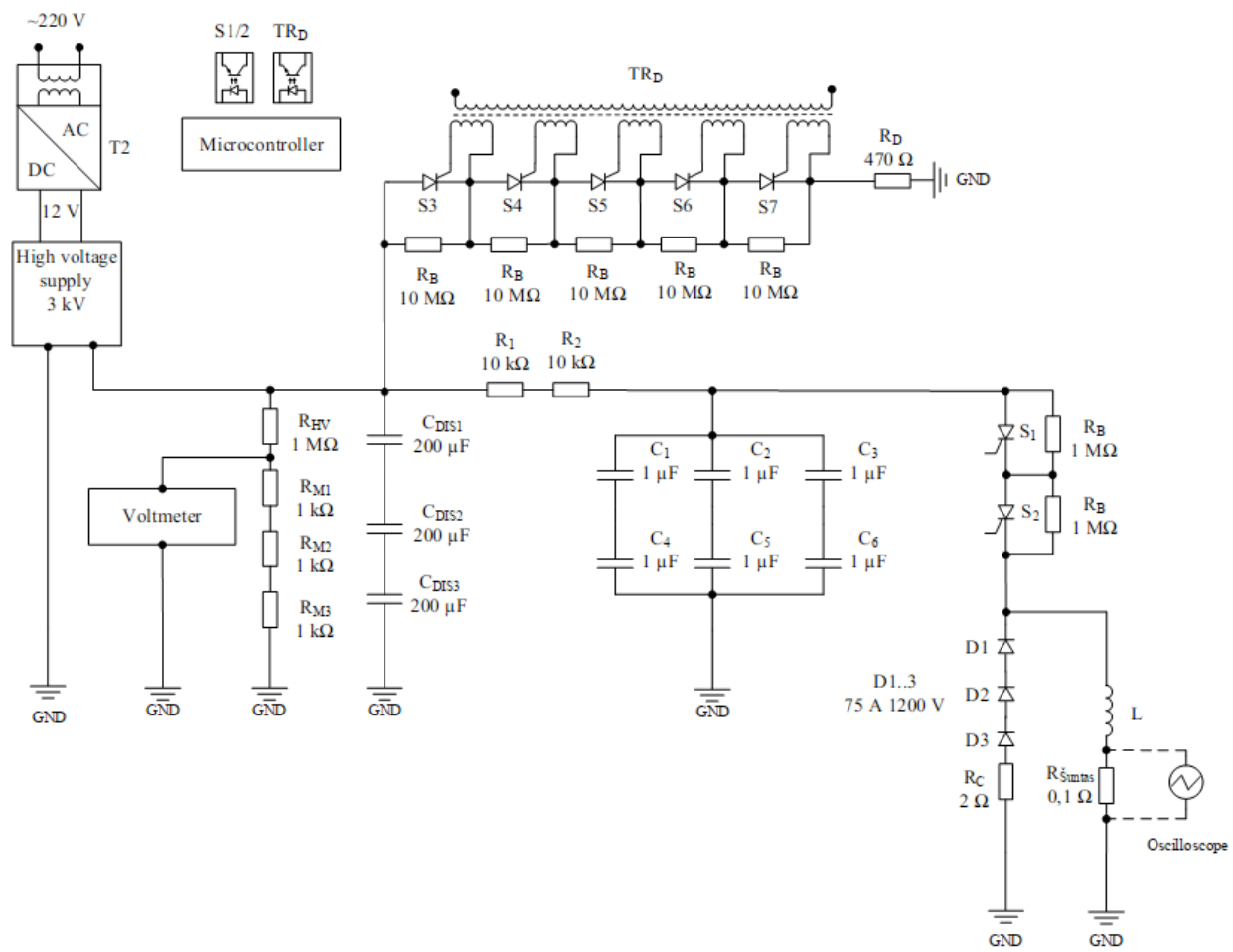

Fig. S2.7. Structural scheme of the magnetic field generator based on thyristor switches

(V. Novickij et al., 2020)

The supply circuit consists of two capacitor batteries analogous to an ignitron-based generator, providing the ability to generate repetitive pulses. The first capacitor bank consists of filter type capacitors (KNG1914, ISKRA, Slovenia) $(3 \times 200 \mu \mathrm{F}$ in series $=$ $66.67 \mu \mathrm{F})$ and the second high $\mathrm{dI} / \mathrm{dt}$ pulse capacitors $(940 \mathrm{C} 20 \mathrm{~W} 1 \mathrm{~K}-\mathrm{F}$, Cornell Dobilier, USA; $6 \times 1$ sequential and parallel $=1.5 \mu \mathrm{F}$ ). The charging voltage of the capacitor batteries was limited to $3 \mathrm{kV}(0-3 \mathrm{kV})$ using a UM4 $* 4$ (Spellman, USA) voltage converter. A $20 \mathrm{k} \Omega$ resistor is used between the individual capacitor batteries, which limits the charging current of the pulsed capacitors. The circuit supports the frequency of repetitive pulses up to $5 \mathrm{~Hz}$. The main generator switches (thyristors) were connected in series to increase the maximum switching voltage to $3.2 \mathrm{kV}$. Any type of inductor with a recommended inductance value of $<10 \mu \mathrm{H}$ can be used as a load in this generator to provide a current of $>1 \mathrm{kA}$ and sufficient rise/fall times for magnetoporation. A photo of the generator prototype is shown in Fig. S2.8. 
a)

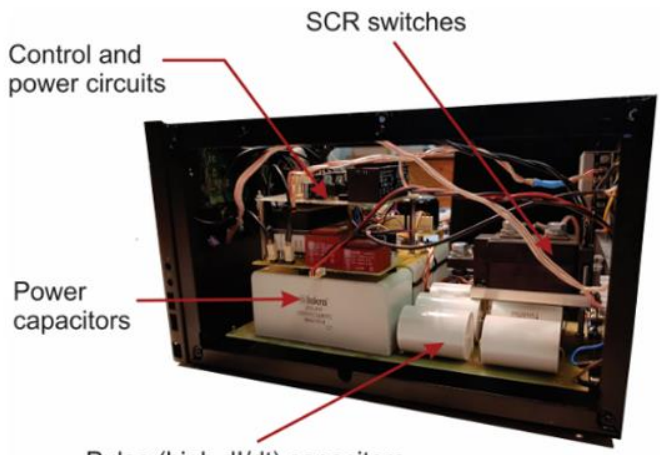

Pulse (high dl/dt) capacitors

b)

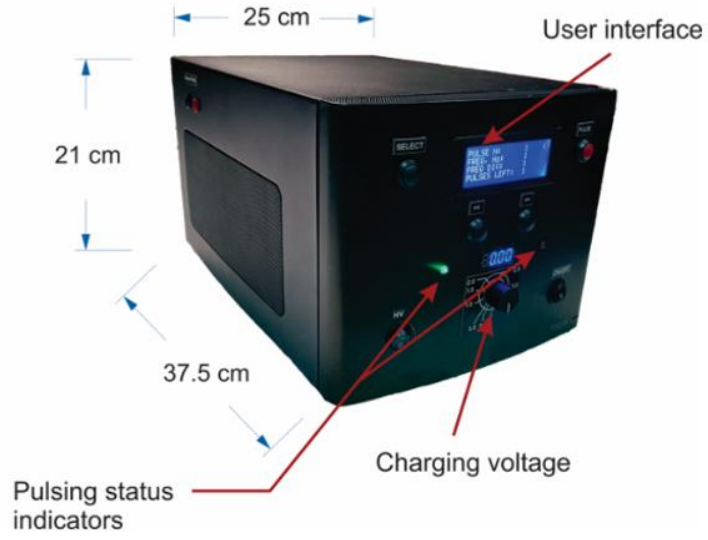

Fig. S2.8. Developed generator: a) The electronic components; b) the housing

(V. Novickij et al., 2020)

Similarly, to the ignitron-based generator, an emergency discharge circuit (S3-S7) was introduced. It is activated by a galvanically isolated trigger (TRD), which is controlled by a button separately from the main microcontroller (XMEGA128, Atmel, USA). Three different inductors $(11.8-14 \mu \mathrm{H})$ were used for load, varying the effective volume and winding number. The following coils were developed: Coil $1:(6 \mathrm{~L} \times 8 \mathrm{~W}$, wire: $0.5 \mathrm{~mm}$, $\mathrm{r}=2 \mathrm{~mm})$; Coil 2: $(6 \mathrm{~L} \times 8 \mathrm{~W}$, wire: $0.8 \mathrm{~mm}, \mathrm{r}=2 \mathrm{~mm})$; Coil $3:(6 \mathrm{~L} \times 8 \mathrm{~W}$, wire: $0.8 \mathrm{~mm}$, $\mathrm{r}=3 \mathrm{~mm}$ ), where $\mathrm{L}$ and $\mathrm{W}$ are layers and windings, respectively. The minimum diameter of the inner coils was adjusted to match the diameter of a standard $0.2 \mathrm{ml}$ sterile PCR tube (ABgene, ThermoFisher Scientific, USA). Photographs of inductors and resultant pulse shapes are shown in Fig. S2.9.

Coil 1 was selected as optimal to be used as a load due to the highest $\mathrm{d} B / \mathrm{d} t$ ratio. When longer sequences of pulse are generated (e.g. 300 pulses), the temperature is also successfully limited to a range of $\pm 5{ }^{\circ} \mathrm{C}$ (Fig. S2.10.). 
a)

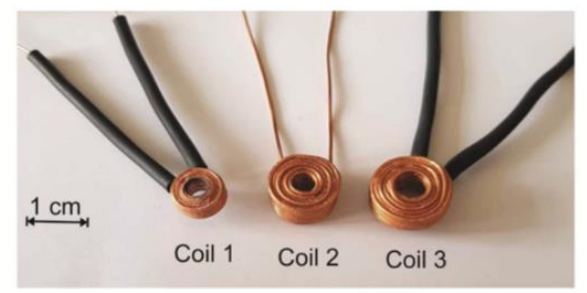

b)

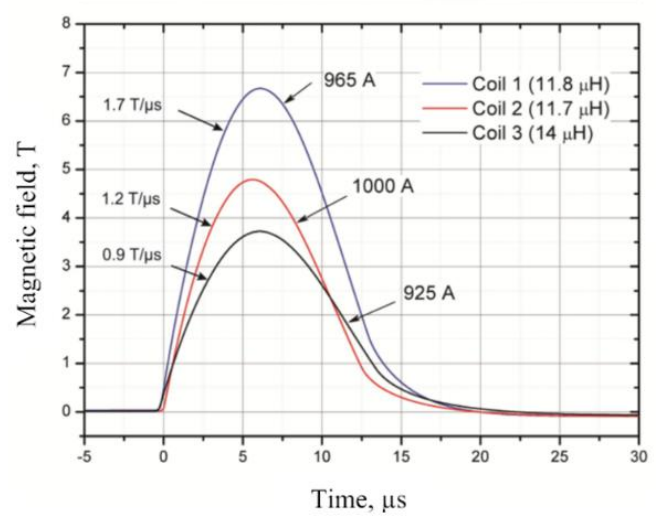

Fig. S2.9. Magnetic field dependence relationship between: a) created inductors;

b) pulse shapes of magnetic fields (Staigvila et al., 2019)

It can be seen that during ice repositioning the average temperature may have increased, however, the deviation was still within the limits that are formed in this dissertation. It was concluded that multilayered high wire density inductors are suitable for generation of high $\mathrm{d} B / \mathrm{d} t$ pulses, and as a load of the proposed high-power generator.

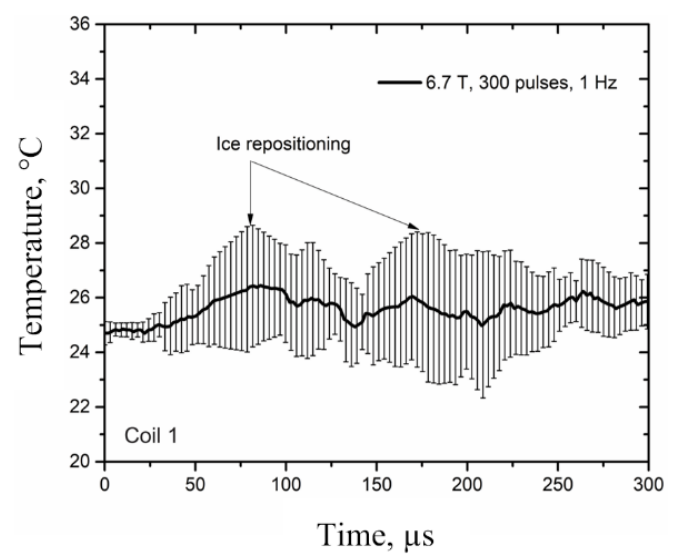

Fig. S2.10. Temperature rise during pulsing (V. Novickij et al., 2020) 
Nevertheless, the induced electric field depends on the geometry of the inductor and the $\mathrm{d} B / \mathrm{d} t$ ratio, therefore, analysis of pulsed should also cover optimization in terms of induced electric field. A trade-off between the magnetic field value, induced electric field and the Joule heating should be made.

\section{Analysis of developed pulsed inductors and applied magnetoporation research}

Magnetoporation requires a suitable generator capable of generating high $\mathrm{d} B / \mathrm{d} t$ pulses. Regardless of the pulse generating circuit, the load on the generator is the inductor, but the structure of the inductor may vary, i.e. the number and cross-section of the windings, the inner and outer diameters and the height of the coil can be varied. In order to evaluate the influence of coil parameters on the induced transmembrane potential COMSOL Multiphysics software was used.

Increasing the number of inductor windings and changing the shape also changes the load inductance, which significantly affects the rise-times of the generated pulses. However, in order to evaluate the values of the transmembrane potential and thus predict the effects on biological objects, the coils used in the previous section were examined by changing the magnetic pulse rise-time.

Two coils were used for the study by varying the internal volume and wire thickness. Coil parameters: Coil A: $6 \mathrm{~L} \times 8 \mathrm{~W}$, wire $\mathrm{d}=0.5 \mathrm{~mm}$, coils $\mathrm{r}=2 \mathrm{~mm}$; Coil C: $6 \mathrm{~L} \times 8 \mathrm{~W}$, wire $\mathrm{d}=0.8 \mathrm{~mm}$, coil $\mathrm{r}=3 \mathrm{~mm}$, where: $\mathrm{L}-$ coil layers, $\mathrm{W}-$ number of windings. 3 bell-shaped current pulses with different rise-time were used to study the dependence of the generated fields: $100 \mathrm{~ns}, 300 \mathrm{~ns}, 1000 \mathrm{~ns}$, limited to the same discharge current $\mathrm{I}_{\max }=1000 \mathrm{~A} \pm 30 \%$.

The shape of the simulated magnetic pulses is shown in Fig. S3.1. It can be seen that the pulse shape corresponds to the shape of the pulses empirically obtained in the previous section, but the pulse duration was artificially reduced to establish further justification and actuality of the pulse duration reduction in magnetoporation studies.

The peak value of the induced transmembrane potential was evaluated analytically for both inductor structures. The results are presented in Table S3.1. The Krasowska analytical model was used for the analysis (Krassowska and Filev, 2007).

It can be seen that sub-microsecond range rise-time pulses can be seen to induce a higher transmembrane potential, which according to electroporation theory is better for pore formation, but recent studies (Novickij et al., 2018, 2020) suggest that only marginal ( $\mathrm{mV}$ order) transmembrane potential should be achieved during magnetoporation. Also, using the Marx generator developed in this dissertation, it was also found that reducing the pulse rise-time is not an effective way to achieve better permeabilization (V. Novickij et al., 2018). 


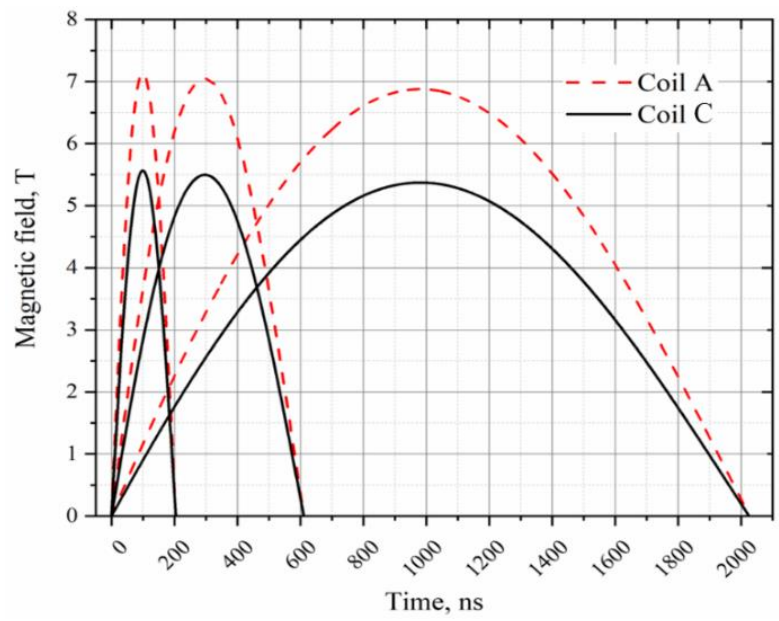

Fig. S3.1. Simulated pulses with different rise and fall times

The same or even better permeabilization efficiencies can be achieved using microsecond pulses (V. Novickij, Dermol, Grainys, et al., 2017; Novickij et al., 2020). Therefore, further applied research was performed using the third thyristor-based generator and Coil A. Chinese hamster ovary cells (European Authentic Cell Culture Collection ECACC, cells CHO-K1, Cat. No. 85051005) were used.

Table S3.1. The dependence of induced transmembrane voltage on pulse parameters

\begin{tabular}{|c|c|c|c|}
\hline Pulse rise time & $100 \mathrm{~ns}$ & $300 \mathrm{~ns}$ & $1000 \mathrm{~ns}$ \\
\hline Coil A & $-0.25 \mathrm{~V}$ & $-0.14 \mathrm{~V}$ & $-0.055 \mathrm{~V}$ \\
\hline Coil C & $-0.19 \mathrm{~V}$ & $-0.11 \mathrm{~V}$ & $-0.042 \mathrm{~V}$ \\
\hline
\end{tabular}

To detect permeabilization, the cell suspension was mixed with propidium iodide to a final concentration of $136 \mu \mathrm{M} .40 \mu \mathrm{l}$ of the cell-dye mixture was transferred to a $0.2 \mathrm{ml}$ PCR tube and treated with a strong pulsed magnetic field.

The generator was tested using the maximum amplitude of Coil A $(6.7 \mathrm{~T}, 17 \mathrm{~V} / \mathrm{cm})$, and 100, 200, and 300 pulse sequences were generated using a repetition rate of $1 \mathrm{~Hz}$. The inductor was constantly cooled with ice, thus stabilizing the temperature. Analysis was performed using flow cytometry (Life Technologies, Attune NxT, USA). Permeabilization was determined as the increase of mean fluorescence value of the measured signal (MFI). The results are presented in Fig. S3.3. 


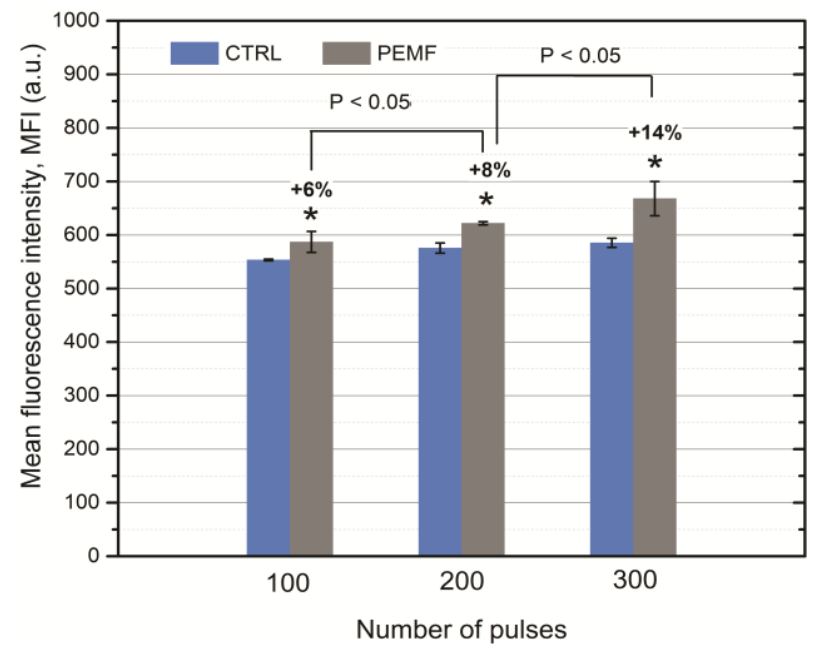

Fig. S3.3. Magnetoporation of CHO cells, where CTRL - control;

PEMF - cells were exposed to a strong pulsed magnetic field;

* - statistically significant $(\mathrm{P}<0.05)$ differences (V. Novickij et al., 2020)

It can be seen that exposure of cells to a strong magnetic field increases the permeability of the cell membrane to fluorescent dyes, indicating successful magnetoporation. The effect also depends on the number of pulses. It has been found that the developed generator capable of switching currents up to $1.5 \mathrm{kA}$ and supporting inductive loads $>5 \mu \mathrm{H}$ can be successfully applied in cell permeabilization experiments. Pulses in the microsecond range of $6.7 \mathrm{~T}, 17 \mathrm{~V} / \mathrm{cm}$ have been shown to be sufficient to induce magnetoporation in vitro. Nevertheless, the amplitude of the induced transmembrane potential was only $10 \mathrm{mV}$.

\section{General conclusions}

1. A Marx generator topology is suitable for generation of sub-microsecond rise time magnetic field pulses and is applicable in magnetoporation field.

2. An ignitron-based circuit for sub-microsecond rise-time pulse generation ensures better control of pulse sequence parameters compared to Marx generator topology.

3. Ignitron-based pulse generator is suitable for generation of repetitive pulses up to $5 \mathrm{kA}$ with 650-700 ns rise times, using loads close to short circuit.

4. Multilayer inductors ensure sufficient magnetic field amplitude and control of the temperature rise, while the inhomogeneity of the induced electric field is the main limitation of this typical inductor structure.

5. The proposed generator based on thyristor switches is suitable for inducing magnetoporation in mammalian cells, while the temperature change in the cell suspension does not exceed $5{ }^{\circ} \mathrm{C}$. 


\section{Priedai $^{3}$}

A priedas. Disertacijos autoriaus sąžiningumo deklaracija

B priedas. Bendraautorių sutikimai teikti publikacijose skelbtą medžiagą mokslo daktaro disertacijoje C priedas. Autoriaus mokslinių publikacijų disertacijos tema kopijos

${ }^{3}$ Priedai pateikiami pridètoje kompaktinèje plokšteleje. 
Gediminas STAIGVILA

MIKROSEKUNDINIỤ MAGNETINIŲ IMPULSŲ

GENERATORIỤ KÜRIMAS LĄSTELIỤ PLAZMINĖS

MEMBRANOS PRALAIDUMUI VALDYTI

Daktaro disertacija

Technologijos mokslai,

elektros ir elektronikos inžinerija (T 001)

DEVELOPMENT OF MICROSECOND MAGNETIC

PULSE GENERATORS FOR CELL MEMBRANE PERMEABILIZATION CONTROL

Doctoral Dissertation

Technological Sciences,

Electrical and Electronic Engineering (T 001)

202012 04. 8,0 sp. I. Tiražas 20 egz.

Leidinio el. versija https://doi.org/10.20334/2020-044-M

Vilniaus Gedimino technikos universitetas,

Saulètekio al. 11, 10223 Vilnius,

Spausdino BI UAB „Baltijos kopija“,

Kareivių g. 13B, 09109 Vilnius 